MARIANA ANDRADE TORRES

Efeito da adição de plasma seminal nas características da motilidade e na fertilidade de espermatozoides criopreservados de suínos

PIRASSUNUNGA 
Efeito da adição de plasma seminal nas características da motilidade e na fertilidade de espermatozoides criopreservados de suínos

Dissertação apresentada ao Programa de PósGraduação em Reprodução Animal da Faculdade de Medicina Veterinária e Zootecnia da Universidade de São Paulo para obtenção do título de Mestre em Ciências.

\section{Departamento:}

Reprodução Animal

Área de concentração:

Reprodução Animal

\section{Orientador:}

Prof. Dr. André Furugen Cesar de Andrade

De acordo

Orientador 
Autorizo a reprodução parcial ou total desta obra, para fins acadêmicos, desde que citada a fonte.

DADOS INTERNACIONAIS DE CATALOGAÇÃO-NA-PUBLICAÇÃO

(Biblioteca Virginie Buff D’Ápice da Faculdade de Medicina Veterinária e Zootecnia da Universidade de São Paulo)

Torres, Mariana Andrade

Efeito da adição de plasma seminal nas características da motilidade e na fertilidade de espermatozoides criopreservados de suínos / Mariana Andrade Torres. -- 2015.

107 p. il.

Dissertação (Mestrado) - Universidade de São Paulo. Faculdade de Medicina Veterinária e Zootecnia. Departamento de Reprodução Animal, Pirassununga, 2015.

Programa de Pós-Graduação: Reprodução Animal.

Área de concentração: Reprodução Animal.

Orientador: Prof. Dr. André Furugen Cesar de Andrade.

1. Espermatozoide. 2. Suíno. 3. Membrana. 4. Plasma seminal. 5. Fertilidade. I. Título. 


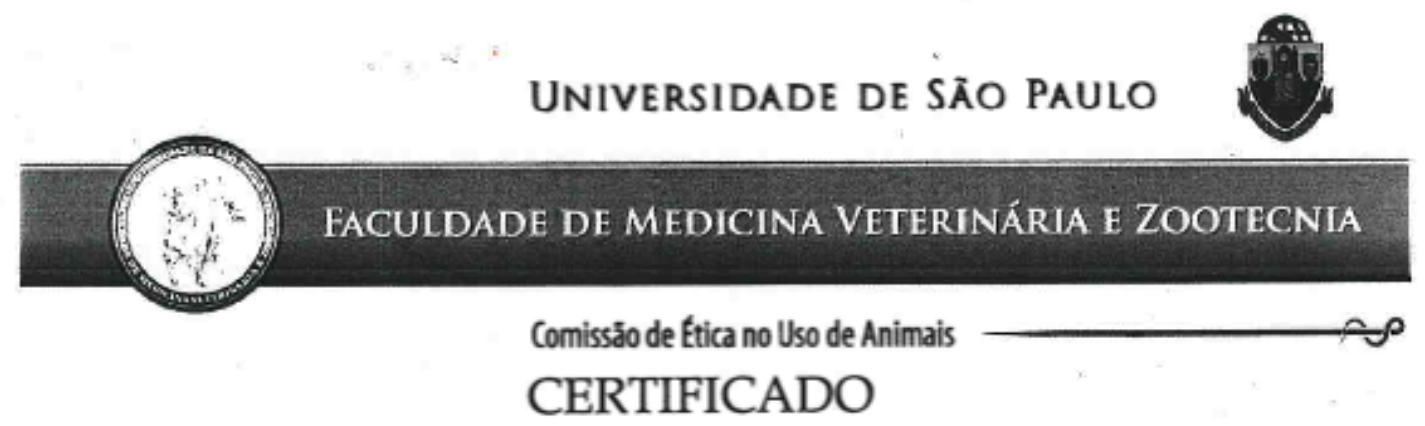

Certificamos que o Projeto intitulado "Efeito da adição de plasma seminal nas características da motilidade e na fertilidade de espermatozoides criopreservados de suínos", protocolado sob o ${ }^{\circ}$ 3066/2013, utilizando 6 (seis) suinos, sob a responsabilidade do(a) Prof. Dr. André Furugen Cesar de Andrade, foi aprovado em reunião de 14/8/2013 e está de acordo com os princípios éticos de experimentação animal da Comissão de Ética no Uso de Animais da Faculdade de Medicina Veterinária e Zootecnia da Universidade de São Paulo.

We certify that the Research "Effects of seminal plasma on motility characteristics and fertility of cryopreserved boar sperm", protocol number 3066/2013, utilizing 6 (six) swine, under the responsibility Prof. Dr. André Furugen Cesar de Andrade, was approved in the meeting of day 8/14/2013 and agree with Ethical Principles in Animal Research adopted by Ethic Committee in the Use of Animals of the School of Veterinary Medicine and Animal Science of University of São Paulo.

São Paulo, 14 de agosto de 2013.

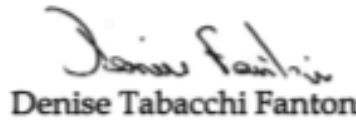

Presidente 


\section{FOLHA DE AVALIAÇÃO}

Autor: TORRES, Mariana Andrade

Título: Efeito da adição de plasma seminal nas características da motilidade e na fertilidade de espermatozoides criopreservados de suínos

Dissertação apresentada ao Programa de Pósgraduação em Reprodução Animal da Faculdade de Medicina Veterinária da Universidade de São Paulo para obtenção do título de Mestre em Ciências.

Data:

\section{Banca Examinadora}

Prof. Dr.:

Instituição: Julgamento:

Prof. Dr.:

Instituição: Julgamento:

Prof. Dr.:

Instituição: Julgamento: 
edico essa dissertação in memoriam a minha avó Benedita.

Mais que minha avó, a senhora foi minha mãe, foi responsável por parte da minha criação, me ensinou rigorosamente o certo e o errado. Os principios de vida, que tenho hoje, sãa resultados dessa formação ef foram eles que me mantiveram firme nessa jornada apesar de todas as intempéries.

Tó, gostaria imensamente que a senhora estivesse aqui, e pudesse comemorar comigo mais essa etapa. Gostaria que durante toda essa trajetória a senhora estivesse ao meu lado, mesmo que distante, mas sempre rezando por mim. Gostaria de poder, durante as tempestades da vida, sentar a mesa no domingo e ter a felicidade, em sua forma mais simples, posta sobre ela, acho que esse trecho de música diz muito sobre nossos almoços de domingo:

" Wó, junta toda a dor desse planeta

Shama pra um almoço de domingo

S a tristeza com certeza vai anoitecer, soryindo"

Benvinda

(Rafinha Acústico, 2013)

Sei que a senhora continua intercedendo por mim, mas era tão bom ter a sua presença... 


\section{Coradecimentos}

À Deus agradeço o dom da minha vida, a segunda chance, a oportunidade de começar tudo de novo.

À minha amada mãe CDona Nônica, obrigada por sempre me apoiar, mesmo na dúvida e na incerteza, obrigada por confiar em mim acima de qualquer coisa, obrigada por acreditar em mim, e claro, obrigada por me ajudar como sempre. Como o papai diz eu sou a "Môniquinha", nosso gênio extremamente parecido nos gerou alguns atritos, mas agradeço a Deus todos os dias por ter me escolhido para ser sua filha e por ter herdado, e aprendido com você os valores da vida. Como você, também sou "turrona", para muitas pessoas essa é uma característica ruim, já eu acredito que tenha um lado bom, aliás, muito bom, é o que nos faz não desistir, e sempre tentar fazer melhor do que os outros imaginam que podemos fazer. Obrigada também por me mostrar e ensinar que o valor das coisas não está no quanto podem nos pagar por elas, mas no quanto batalhamos e suamos para conquista-las. Obrigada por me ofertar tudo aquilo que você não teve, mas sonhou muito em ter. Obrigada por sempre não medir esforços para facilitar a minha vida, se eu consigo ir mais longe é porque você sempre me ajuda a levantar. Obrigada por acreditar na minha escolha, e me apoiar, sem você do meu lado nunca conseguiria alcançar meus objetivos.

Winhas conquistas são fruto dos seus ensinamentos, orações e torcida. Wuito obrigada pore ser a melhor mãe do mundo.!!

Ao $\mathscr{D} \boldsymbol{r}$. Djalma, meu amado pai, obrigada por ser esse exemplo de pessoa, de homem e de profissional. Obrigada por ter me mostrado a maravilha do mundo da Medicina Veterinária, e ao mesmo tempo, me desculpa por não ter seguido suas expectativas de caminho profissional. Obrigada por ter apoiado minha decisão apesar de não concordar plenamente com ela. Obrigada por ter me oferecido tudo aquilo que você nunca pode ter durante sua vida acadêmica. Talvez tudo isso tenha me levado ao caminho que sigo hoje. Pai, você me mostrou que o caminho mais fácil não tem graça, que dá mais prazer conquistar as coisas com a luta diária, foi isso que o senhor fez durante toda sua vida, e foi isso que eu sempre vi o 
senhor fazendo e que ouvia das suas histórias da graduação. Mas, graças a Deus, o senhor me ajudou muito durante toda minha vida escolar, isso tornou meu caminho mais fácil, e eu precisava de algo que fosse um desafio, algo que exigisse mais de mim, e encontrei no caminho que sigo hoje.

\section{E devo essa minha felicidade, em grande parte, ao senhor. . Nuito obrigada pore ser o melhor pai do mundo.!'}

Aos meus irmãos Matheus, Mathias e Maristela, obrigada por sempre estarem presentes apesar da distância, e por ficarem ao lado do papai e da mamãe enquanto eu estou sempre longe. Obrigada por me apoiarem e me ajudarem sempre. Obrigada por serem pontos de referência para mim, por serem meus exemplos, por sempre, desde de pequenininha terem me ensinado, e me mostrado os caminhos da vida. E claro nunca poderia esquecer, obrigada pelos presente maravilhosos que vocês colocaram na minha vida, seus filhos, meus sobrinhos. Obrigada porr serem os melhores irmãos do mundo'. Lmo vocês'!

Aos meus amados sobrinhos Yulia, Maria Glara, Goño Pedro (in memoriam), Gabrielle, Maria Mice e Titor, cada notícia da vinda de um de vocês coloria cada vez mais a minha vida, hoje, graças a Deus, tenho um arco-íris de sete lindas cores, de sete lindos sobrinhos que colorem e alegram minha vida a cada dia, seja perto ou longe, que ainda posso pegar no colo e abraçar, ou que está no céu olhando por todos os outros, meu amor por vocês é incondicional.

Obrigada por, sem mesmo saber, melhorarem meu dia apenas com a presença, o sorriso, o abraço, o beïo, por apenas serem meus presentes.

Ao meu amado afilhado e sobrinho $\mathcal{G}$ abriel, meu loiro azedo, a honra de ser sua madrinha foi a maior que poderia receber em toda minha vida. Minha alegria em te ver crescer, aprender e evoluir é enorme, a sua inteligência é incrível; e o seu jeitinho, seu caráter e sua personalidade se fossem mais parecida com as da Didi, seriamos a mesma pessoa. Quero sempre estar a seu lado, para te ajudar em cada passo da sua caminhada, a cada obstáculo que aparecer, te ensinar tudo que aprendi, para que não cometa os mesmos erros e chegue a ser 
um homem digno, responsável, inteligente, trabalhador e honrado. Te amo com todas as forças que tenho em meu coração.

\section{Obrigada por ser a minha mais pura razão de viver.}

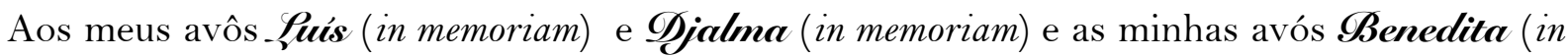
memoriam) e Tilda, hoje tenho a certeza que os princípios de vida que tenho, não vieram apenas dos meus pais, isso vem de antes, veio de vocês. Sempre adorei escutar suas histórias de vida, e em cada uma delas sempre aprendia alguma coisa, sempre tinha uma lição. E foi vendo o esforço e dedicação de cada um de você com meus pais, seus filhos, e o que ensinaram e eles, e que eles passaram a mim e a meus irmãos, que fui capaz de hoje chegar onde estou.

Obrigada por colocarem no mundo as duas pessoas que mais amo. Lmo vocês, aqui na Terya e lá no céu!

Às minhas cunhadas Soraya e Gleice e ao meu cunhado $\mathscr{T} \boldsymbol{k} k \boldsymbol{k}$ pelo apoio, por sempre estarem ao lado dos meus amados irmãos quando não posso estar, e por terem me dados os melhores presentes de toda minha vida.

Às minhas amigas e irmãs do coração Tal e $\boldsymbol{S a}_{\boldsymbol{a}}$ obrigada por essa longa, linda e verdadeira amizade, que a distância não faz nem cócegas! Obrigada por sempre estarem dispostas quando mais precisava, quando precisava de uma longa conversa, ou quando precisava de um simples e longo abraço! Gordinha, obrigada pelos longos, longuíssimos e-mails trocados, sei que muitas pessoas podem pensar: "nossa mas que forma mas impessoal de conversar", mas é incrível e eu adoro receber teus e-mails e poder te enviar e-mails de páginas e mais páginas!!! Amo muito vocês!

À minha amiga e afilhada Gacau minha florzinha, como sinto falta de nossos dias juntas, mas te agradeço muito pois não só mais nossa linda amizade que nos une, vou te ter pra sempre como minha afilhada, e nenhuma distância pode abalar nossa amizade. Obrigada pelas horas de mensagens trocadas no whats, ou de ligações para aquele desabafo necessário, obrigada 
por sempre me ouvir e me aconselhar bem, você me conhece tão bem, afinal somos TÃO parecidas! Te amo!

Às minhas companheiras de morada atuais e de casas passadas: Robertinha, Marccela, Thais, Marta, Dani, Mireli, Filhote, Pistola, fina, muito obrigada pelo companheirismo em todos os momentos, desde a descontração, nos almoços de fim de semana e de uma boa cerveja, até por me compreenderem nos momentos que chegava megamaster-blaster-plus-estrelinhas-e-unicórnios estressada do laboratório.

Aos funcionários do Laboratório de Pesquisa em Suínos, Fabinho, Marcão, Ghiquinho e Ricardo, e todos os outros funcionários que passaram pela granja, auxiliando sempre em todo processo experimental, sempre disponíveis para a lida com os animais, do trato a limpeza, do manejo a hormonioterapia, dos cafés aos churrascos... sem vocês, sem a ajuda e cooperação de cada um de vocês esse trabalho seria impossível de ser realizado.

\section{Nuito obrigada pore ajudar" a cuidar" das "meninas" e "meninos" desses experimento.}

Às secretárias do departamento $\mathscr{H a r} \boldsymbol{u m}$ i, Thais e $\mathscr{R o b e r t a}$ e ao secretário Glayton, muito obrigada por toda a cooperação e presteza em todos os momentos, por sempre estarem dispostos a ajudar, vocês foram fundamentais.

Aos colegas de departamento pelo companheirismo e amizade.

À Parissa e à Glaudia por toda ajuda e paciência em ensinar todo o necessário nos meus primeiros passos na granja e pela confiança para ajudar em seus experimentos.

À $\mathscr{R o m m y ~ e ~ a o ~} \mathscr{R o d r i g o ~ p o r ~ t o d a ~ a ~ a j u d a ~ d u r a n t e ~ n o s s o s ~ e x p e r i m e n t o s , ~ p e l o ~ e n s i n a m e n t o s , ~}$ pelos momentos compartilhados e pela paciência com a minha chatice no laboratório. E à Rommy pela confiança das suas análises, pelo companheirismo, pelas conversas, e por toda ajuda durante minha estadia no Chile.

Gspero levar essa amizade por muitos anos, obrigada porc tudo! 
À toda a equipe do Paboratorio de Producción Animal e do Paboratorio de Tecnologia da Garne da Universidad de La Frontera (Chile) por me receber de braços abertos, me ajudar nas dificuldades do idioma, me ensinar não só técnicas laboratoriais mas também o idioma, cultura e por me passar um pouco da experiência de vida de cada um de

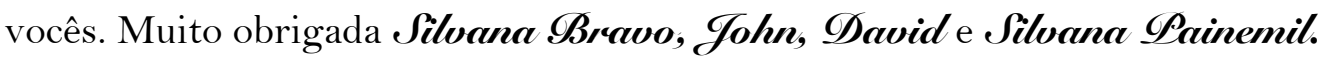

Aos alunos de iniciação científica $\mathscr{B} r$ runo (Qualé), Beatriz (Sosua), Lnoã (Santa), Frernando (Rick), André (Garäjo), Yuliana (Liracanjuba) obrigada por toda ajuda na granja e com os animais!

À equipe do Laboratório de Andrologia e Tecnologia de Embriões Suínos, Gisele, Giego, Melissa, Gustavo, Tictor, esse trabalho é NOSSO, cada um de vocês foi essencial na execução desse trabalho! Agradeço muito vocês por toda a ajuda, pelos fins de semana dedicados ao experimento, pelas noites viradas no citômetro, pela paciência com as minhas chatices e com a coleta dos machos, por apesar de tudo ficarem no laboratório para ajudar, pela ajuda na seleção das marrãs, com a maçante hormonioterapia e coleta de embriões, enfim... por cada momento que passamos, sejam eles bons ou ruins, acredito que todo momento teve sua importância.

Sunca poderei agradecer vocês da maneira que merecem, mas deixo aqui o meu sincero obrigada, por toda ajuda que recebi de cada um de vocês.'

Ao $\mathscr{P} r o f \mathscr{F}$ elipe $\mathscr{P} e r e c i n$ e a pós-graduanda Maitê $\mathscr{D}$ el Golado, por auxiliar nossa equipe com os embriões, cedendo meios-de-cultura e conhecimentos essenciais.

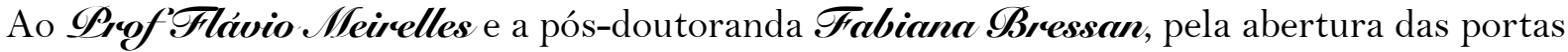
do laboratório, por ceder o citômetro de fluxo e pela confiança do equipamento, e pelo auxílio com as análises dos embriões. F́abi, tenho uma admiração muito grande pelo seu profissionalismo, empenho e pela incrível qualidade do seu trabalho, você é um dos meus espelhos de profissional. Obrigada por toda ajuda de sempre. 
Ao $\mathscr{P}$ rof $\mathscr{T}$ eidge $\mathscr{T}$ rukumasu e a pós-graduanda Lrina $\mathscr{R o c h e t t i , ~ p o r ~ c e d e r ~ u m ~ " p e q u e n o ~}$ grande” espaço para nossas amostras no freezer, facilitando muito nosso trabalho.

Ao Prof Nárcio $\mathscr{B}$ inelli e a toda equipe do LFEM, por ceder a bomba de vácuo, facilitando muito nosso processamento do plasma seminal, e abrir um espaço para acondicionar nossas amostras.

À $\mathscr{P r o f}$ Enciva Garla e toda equipe do LEPPaR, principalmente à Waira (ODoci), pela ajuda e ensinamentos nos meus primeiros passos no laboratório e pela confiança para ajudar no experimento e ao Leonardo (Gati), pela confiança para ajudar no experimento.

À $\mathscr{P}_{\mathbf{r}} \mathscr{f}$ Simone por nunca medir esforços para ajudar em toda e qualquer parte do trabalho, desde das análises estatísticas até limpar baia, quando necessário. Tenho uma admiração muito grande pela incrível e completa profissional que você é, e de todos os profissionais acadêmicos que conheço hoje, digo-te que quando penso no tipo de profissional que quero ser, me espelho muito em você, e quero um dia poder ser, ao menos, um pouco do que você é.

Ao $\mathscr{P}$ rof Lnibal pela grandes oportunidades, pelos conselhos, pela abertura das portas da granja, pela confiança e carinho de sempre.

Ao $\mathscr{D r o f . ~ M e ́ s t o r ~ p o r ~ a c e i t a r ~ a ~ m i n h a ~ c o t u t e l a ~ e ~ p o r ~ a ~ c a d a ~ i n s t a n t e ~ d a ~ m i n h a ~ e s t a d i a ~ n o ~}$ Chile estar preocupado com o meu bem-estar. Obrigada por todas as oportunidade de auxiliar nos experimentos. Muito obrigada, Professor, por todas "las invitaciones" cada momento foi incrível e estará guardado na minha memória e no meu coração para sempre.

Ao $\mathscr{P}_{\boldsymbol{r a f}}$ Gabral o meu eterno obrigada por ter sido o meu grande incentivador, professor, amigos e psicólogo. Muito obrigada por todos os ensinamentos, e por ter me ajudado a não desistir nos momentos difíceis. Obrigada por ter me mostrado e me dado a oportunidade de ingressar num mundo pelo qual me apaixonei, e ter me ensinado a fazer meu trabalho com prazer. 
Ao $\mathscr{P r o f . ~ L n d r e ́ , ~ o b r i g a d a , ~ a c i m a ~ d e ~ t u d o , ~ p e l a ~ o p o r t u n i d a d e ~ e ~ c o n f i a n c ̧ a , ~ s e m ~ a s ~ q u a i s ~ n a d a ~}$ mais seria possível. Em primeiro lugar, obrigada por não ter confiado em mim de cara, confesso que no começo foi muito difícil isso, pois estava (mal) acostumada, mas acredito que isso me ajudou muito no meu desenvolvimento inicial, foi um grande desafio conquistar sua confiança. No meu primeiro processo seletivo cada vez que você me falava "Você sabe que você não vai passar, né?”, que não foram poucas vezes, eu pensava comigo: "Eu vou passar e vou mostrar para esse japonês". Acredito que foi essa sua dúvida que me motivou, mas infelizmente meu curriculum não ajudou, né? Mas como você sempre me fala as coisas acontecem no momento certo, esse tempo a mais que passei aqui, me ajudou muito, tanto para melhorar meu curriculum quanto para uma melhora pessoal e profissional, e tenho que te agradecer, pois você me ajudou muito nisso. E o tempo chegou e passou, muita coisa aconteceu... foram muitos fatos, mas um ficou especialmente marcado para mim, o dia que você me ligou (no meio das castrações do experimento da Maíra) perguntando se eu topava assumir a parte de citometria da equipe, lembro de todos os fatos que circundaram essa pergunta, pois te garanto que me marcou muito. Ao te falar "sim" não imaginava todas as implicações que viriam, imaginei que seria fácil, mas não foi, mas foi exatamente por isso que me envolvi e me apaixonei tanto por essa área. André, obrigada por cada um dos ensinamentos, puxões de orelha, conselhos, conversas, orientações e até as piadas ruins para distração. Obrigada por sempre me incentivar a crescer, progredir e melhorar, nossas conversas, e cada um dos seus conselhos são muito bem guardado, e sempre volta a tona alguma conversa na minha cabeça em um momento que preciso. Obrigada por não desistir de mim, apesar do meu jeito difícil de se lidar, ter paciência e me ajudar a melhorar (aos poucos). Obrigada pela oportunidade do intercâmbio (que foi um experiência incrível), obrigada por me ajudar a retomar meu norte nas vezes que estava perdida, e com as suas conversas (de horas... mas boas horas!) me ajudavam a não desistir e seguir em frente. Obrigada, por sempre, da sua maneira, ser o melhor orientador que eu poderia ter! Você sabe quantas vezes eu quis desistir e ir embora, mas o que nunca me deixou foi o medo de não poder encontrar outro orientador como você! Você foi e é (e espero que continue sendo) o melhor orientador que eu poderia ter!

Obragada por ter me mostrado que apesar de todas as dificuldades é possível seguir o sonho. 
Ao Programa de Pos-graduação em Reprodução Lnimal, à Fraculdade de Nedicina Teterinária e Zootecnia e à Universidade de São Caulo pela oportunidade do mestrado.

A Trundação de Lmparo a Pesquisa do Estado de São $\mathscr{P a u l o}$ - FAPESP pelo apoio financeiro ao projeto de pesquisa 2011/23484-8, pela bolsa de mestrado concedida no processo 2013/08070-8 e a possibilidade de intercâmbio pelo programa BEPE com o processo 2014/22972-7. 


\section{Epigrafe}

"There are no two words in the world more harmful than 'good job"."

adaptado de Prof. Terence Fletcher em "Whiplash"

(Damien Shazelle, 2014) 


\section{RESUMO}

TORRES, M. A. Efeito da adição de plasma seminal nas características da motilidade e na fertilidade de espermatozoides criopreservados de suínos. [Effect of seminal plasma on motility characteristics and fertility of cryopreserved boar spermatozoa]. 2015. 107f. Dissertação (Mestrado em Ciências) - Faculdade de Medicina Veterinária e Zootecnia, Universidade de São Paulo, 2015.

A criopreservação do sêmen suíno ainda é um desafio devido a extensão dos danos causados pelo choque-frio. Os espermatozoides oriundos da fração rica do ejaculado suíno possuem a membrana plasmática mais estável, são mais resistentes ao choque-frio e a reação acrossomal precoce do que aqueles oriundo da fração total do ejaculado. Com isso, o uso do plasma seminal oriundo dessa fração do ejaculado suíno também poderia aumentar a criotolerância dos espermatozoides suínos e/ou reverter os danos oriundo da criopreservação. Entretanto, a grande maioria das técnicas de avaliação espermática inclui apenas um parâmetro de funcionalidade espermática. Por outro lado, quanto mais características espermáticas analisadas, mais fiel se torna a avaliação quanto ao potencial fertilizante da amostra. Nesse contexto, esse trabalho objetivou a validação de uma técnica de análise espermática por citometria de fluxo para a avaliação simultânea da integridade das membranas plasmática e acrossomal e potencial de membrana mitocondrial. Além de avaliar os efeitos da adição/manutenção do plasma seminal oriundo da fração rica do ejaculado suíno sobre a cinética espermática, integridade das membranas plasmática e acrossomal e potencial de membrana mitocondrial, fluidez e peroxidação das membranas espermáticas, fosforilação do aminoácido tirosina, taxa de fertilidade e de prenhez precoce. A técnica sugerida em nosso trabalho é capaz de detectar $\left(\mathrm{R}^{2}=0,9356 ; \mathrm{p}<0,01\right)$ simultaneamente os espermatozoides com a membrana plasmática e acrossomal integras e alto potencial de membrana mitocondrial (PIAIA). O plasma seminal da fração rica do ejaculado suíno gera benefícios para a cinética espermática melhorando a motilidade total e progressiva dos espermatozoides descongelados $(\mathrm{p}<0,05)$. Por outro lado, a manutenção/adição de plasma seminal oriundo da fração rica do ejaculado suíno, não é capaz de alterar $(\mathrm{p}>0,05)$ os espermatozoides PIAIA, a fosforilação do aminoácido tirosina, a fluidez e a peroxidação das membranas espermáticas. Entretanto, essas características devem ser cuidadosamente interpretadas, uma vez que, a fluidez e a peroxidação das membranas espermáticas são alteradas $(\mathrm{p}<0,05)$ pelo processo de centrifugação. As taxas de fertilidade e de prenhez precoce também não foram influenciadas $(\mathrm{p}>0,05)$ pela adição de plasma seminal oriundo da fração rica do ejaculado suíno. Portanto, podemos concluir que o plasma seminal da fração rica possui efeito benéfico sobre a 
fisiologia dos espermatozoides pós-descongelação, melhorando a criopreservação do sêmen suíno.

Palavras-chave: Espermatozoide. Suíno. Membrana. Plasma seminal. Fertilidade. 


\begin{abstract}
TORRES, M. A. Effect of seminal plasma on motility characteristics and fertility of cryopreserved boar spermatozoa. [Efeito da adição de plasma seminal nas características da motilidade e na fertilidade de espermatozoides criopreservados de suínos]. 2015. 107f. Dissertação (Mestrado em Ciências) - Faculdade de Medicina Veterinária e Zootecnia, Universidade de São Paulo, 2015.
\end{abstract}

Boar semen cryopreservation is still a challenge due to the extension of cold shock damage. Boar spermatozoa arising from sperm-rich ejaculate fraction are reported to have a more stable plasma membrane, more resistant to cold shock and premature acrosome reaction than spermatozoa from the whole ejaculate. Thus, seminal plasma arising from whole sperm-rich fraction can increase cryotolerance of boar spermatozoa, and in other domestic species it has the ability to reverse cryopreservation damage. However, the majority of actual sperm evaluation techniques include a single sperm parameter, which makes the sperm characterization of a single population difficult. In this context, this work was performed to validate a sperm flow cytometry fourfold coloration technique for the simultaneous evaluation of plasma and acrosomal membrane integrity and mitochondrial membrane potential. Furthermore, we evaluate the seminal plasma arising from whole sperm-rich fraction effects on sperm kinetics, plasma and acrosomal membrane integrity and mitochondrial membrane potential, tyrosine phosphorylation, membrane fluidity and peroxidation, fertility and early pregnancy rate. The proposed technique is able $\left(\mathrm{R}^{2}=0.9356 ; \mathrm{p}<0.01\right)$ to simultaneous detection of plasma and acrosomal membrane integrity and high mitochondrial membrane potential (IPIAH). Seminal plasma arising from whole sperm-rich fraction is able to improve $(\mathrm{p}<0.05)$ total and progressive motility. Furthermore, seminal plasma arising from whole sperm-rich fraction maintenance/addition was not able to improve $(p>0.05)$ the IPIAH sperm population, tyrosine phosphorylation, membrane fluidity and peroxidation. However, these sperm characteristics need to be carefully interpreted, once, membrane fluidity and peroxidation could be influenced $(\mathrm{p}<0.05)$ by centrifugation. Fertility and early pregnancy rate we not improved $(p>0.05)$ by seminal plasma addition. Therefore, we concluded that sperm fourfold coloration can be used to evaluate simultaneously plasma and acrosomal membranes integrity and mitochondrial membrane potential and that whole sperm-rich fraction seminal plasma can be beneficial to post-thawed sperm physiology, thereby improving boar semen cryopreservation.

Keywords: spermatozoa, swine, membrane, seminal plasma, fertility 


\section{LISTA DE FIGURAS}

Figura 1 - Controles dos fluoróforos utilizados para a compensação manual em citometria de fluxo da coloração quádrupla dos espermatozoides suínos.

Figura 2 - Representação do template de análise dos espermatozoides suínos por coloração quádrupla.

Figura 3 - $\quad$ Preparação e envase do sêmen suíno diluído em diluente de criopreservação

Figura 4 - Obtenção de plasma seminal autólogo.

Figura 5 - $\quad$ Análise computadorizada da motilidade através do software Sperm Class Analyzer.

Figura 6 - Gráficos gerados a partir do software FACSDiva 6.1 para análise da Merocianina-540

Figura 7 - Gráficos gerados a partir do software FACSDiva 6.1. para análise do C11-Bodipy ${ }^{581 / 591}$......

Figura 8 - Linha do tempo esquematizando a hormônio-terapia utilizada para IATF por IAIU 70

Figura 9 - Inseminação intrauterina em tempo fixo. 71

Figura 10 - Processo de lavagem uterina e coleta de embriões.

Figura 11 - Avaliação sob esteriomicroscopia e microscopia de epifluorescência do lavado uterino e tubário.

Figura 12 - Hierarquia dos tratamentos T100, T75, T50, T25 e T0, baseados na porcentagem de células viáveis esperadas em cada amostra. Representação gráfica da diminuição, esperada, da viabilidade celular entre os cinco tratamentos

Figura 13 - Coloração quádrupla para análise espermática por citometria de fluxo.

Figura 14 - Média \pm erro padrão da média do efeito de tratamento sob as características da cinética espermática. 
Figura 15 - Média \pm erro padrão da média do efeito de tempo sob as características da cinética espermática.

Figura 16 - Média \pm erro padrão da média do efeito de tratamento (A) e tempo (B) sob as populações espermáticas avaliadas pela técnica de coloração quádrupla

Figura 17 - Média \pm erro padrão da média do efeito de tratamento para as características de desordem (a) e peroxidação lipídica (b) da membrana plasmática, e fosforilação do aminoácido tirosina (c)

Figura 18 - $\quad$ Média \pm erro padrão da média do efeito de tratamento para as características de desordem e peroxidação lipídica (a) da membrana plasmática, e fosforilação do aminoácido tirosina (b)

Figura 19 - $\quad$ Média \pm erro padrão da média do efeito de tratamento para a taxa de fertilidade e média da taxa de prenhes precoce 


\section{LISTA DE TABELAS}

Tabela 1 - Controles de citometria de fluxo para a compensação da coloração quádrupla de avaliação da integridade das membranas plasmática e acrossomal e potencial de membrana mitocondrial.

Tabela 2 - Médias \pm erro padrão das características de cinética espermática e da integridade das membranas plasmática e acrossomal..

Tabela 3 - Média \pm erro padrão da média da interação tempo x tratamento para a variável retilinearidade (STR). 


\section{LISTA DE ABREVIATURAS e SIGLAS}

a.u. unidades arbitrárias

AIMI espermatozoides com membranas acrossomal e plasmática integras

ALH Amplitude de deslocamento lateral da cabeça

$\mathrm{BCF}$ frequência de batimento

BSPs proteínas do plasma seminal bovino

$\mathrm{Ca}^{+2} \quad$ cálcio

cAMP adenosina monofosfato cíclico

CASA sistema computadorizado de análise espermática

CCCP cianeto carbonado de m-clorofenilhidrazona

$\mathrm{Cl}^{-} \quad$ cloro

$\mathrm{cm} \quad$ centímetros

CTC clortetraciclina

DIC contraste de interferência diferencial

DNA ácido desoxirribonucleico

eCG gonadotrofina coriônica equina

ERO's espécies reativas de oxigênio

FF flash freezing

FITC fluoresceína

FIV fecundação in vitro

FMO fluorescência menos uma

FN-2 fibronectina tipo 2

FR fração rica do ejaculado suíno

$g \quad$ força gravitacional

GPX glutationa peroxidase

GRD glutationa redutase

GSH glutationa

H342 hoechst 33342

HBP proteínas ligadoras de heparina

$\mathrm{Hz} \quad$ hertz

IAIU inseminação artificial intrauterina 
IATF inseminação artificial em tempo fixo

IP iodeto de propídio

JC-1 5, 5',6,6'-tetra- chloro-1,1',3,3'-iodeto de carbocianato de tetraetilbenzomidazol

$\mathrm{K}+\quad$ potássio

kDa quilo Dalton

LH hormônio luteinizante

LIN linearidade

LPO lipoperoxidação

$\mathrm{Mg}^{+2} \quad$ magnésio

$\mathrm{mL} \quad$ microlitros

MP motilidade progressiva

MT motilidade total

$\mathrm{Na}^{+} \quad$ sódio

p probabilidade

PBS tampão fosfato salino

PGE prostaglandina $\mathrm{E}$

PGF $2 \alpha \quad$ prostaglandina F $2 \alpha$

PIAIAP espermatozoides apresentando membrana plasmática e acrossomal integras e alto $\Delta \Psi \mathrm{m}$

PIAIBP espermatozoides com membrana plasmática e acrossomal integra e baixo $\Delta \Psi \mathrm{m}$

PIARAP espermatozoides com membrana plasmática íntegra, acrossomal reacionada e alto $\Delta \Psi \mathrm{m}$

PIARBP espermatozoides com membrana plasmática íntegra, acrossomal reacionada e baixo $\Delta \psi \mathrm{m}$

PKA proteína quinase A

PLAIAP espermatozoides com membrana plasmática lesionada, acrossomal íntegra e alto $\Delta \psi \mathrm{m}$

PLAIBP espermatozoides com membrana plasmática lesiona, acrossomal íntegra e baixo $\Delta \psi \mathrm{m}$

PLARAP espermatozoides com membrana plasmática e acrossomal lesionadas e alto 
$\Delta \psi \mathrm{m}$

PLARBP espermatozoides com membrana plasmática e acrossomal lesionada e baixo $\Delta \psi \mathrm{m}$

PS plasma seminal

PSA Pisum sativum

PSF fração pré-espermática do ejaculado suíno

PSP-I proteína do plasma seminal I

PSP-II proteína do plasma seminal II

PSRF fração pós-espermática do ejaculado suínos

r

coeficiente de correção de Pearson

$\mathrm{R}^{2} \quad$ coeficiente de determinação

SCA Sperm Class Analyser - Software CASA

SAS Stastitical Analysis System

SOD superoxido-dismutase

STR retilinearidade

TALP solução de Tyrode acrescida de albumina, lactato e piruvato

TF taxa de fertilidade

TP taxa de prenhez precoce

UI unidades internacionais

VAP velocidade de trajeto

VCL velocidade curvilinear

VSL velocidade progressiva

X vezes

$\Delta \Psi \mathrm{m} \quad$ potencial de membrana mitocondrial

$\mu \mathrm{g} \quad$ microgramas

$\mu \mathrm{L} \quad$ microlitro

$\mu \mathrm{m} \quad$ micrometros 


\section{LISTA DE SIMBOLOS}

$\begin{array}{ll}\% & \text { porcentagem } \\ < & \text { menor } \\ > & \text { maior } \\ { }^{\circ} \mathrm{C} & \text { graus Célsius } \\ \pm & \text { mais ou menos } \\ { }^{\circledR} & \text { marca registrada } \\ / & \text { por }\end{array}$




\section{SUMÁRIO}

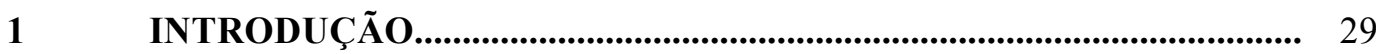

$2 \quad$ REVISÃO DE LITERATURA.............................................................. 33

2.1 OS ESPERMATOZOIDES SUÍNOS E A CRIOPRESERVAÇÃO

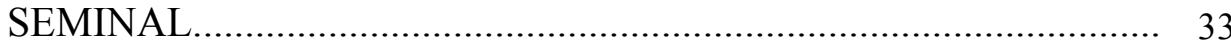

2.1.1 As membranas espermáticas dos espermatozoides suínos e a criopreservação seminal.............................................................................. 35

2.1.2 Fosforilação das proteínas................................................................................. 36

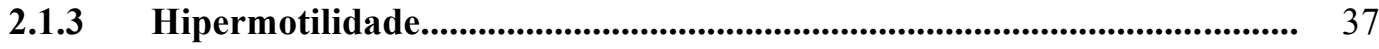

2.1.4 Reação acrossomal.......................................................................................... 38

2.1.5 Mudanças semelhantes à capacitação (criocapacitação)........................... 39

2.2 O PLASMA SEMINAL E SEU IMPACTO NA CRIOPRESERVAÇÃO

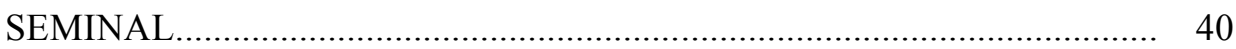

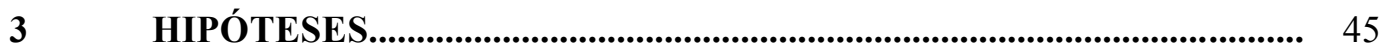

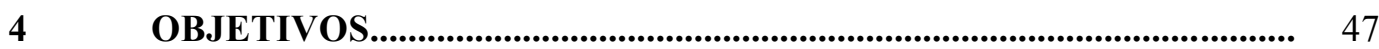

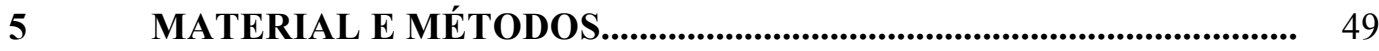

5.1 EXPERIMENTO 1: Validação da técnica de análise simultânea da integridade das membranas plasmática e acrossomal e do potencial de membrana mitocondrial por citometria de fluxo.............................................. 49

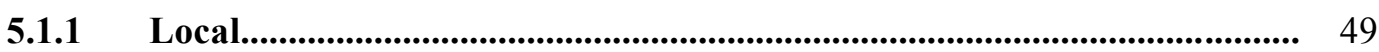

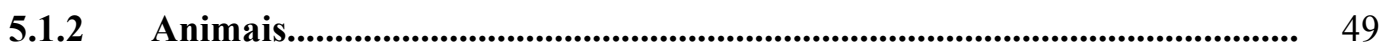

5.1.3 Coleta de sêmen suíno................................................................................ 50

5.1.4 Avaliação espermática.......................................................................................... 50

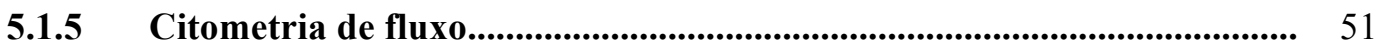

5.1.6 Compensação manual do spectral overlap entre os fluoróforos................. 51

5.17 Tratamentos experimentais................................................................................... 55

5.18 Análise computadorizada da cinética espermática - CASA...................... 55

5.1.9 Validação da técnica de coloração quadrupla dos espermatozoides

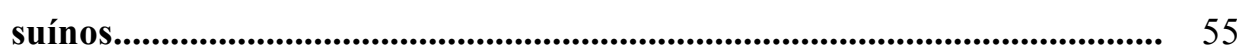

5.2 EXPERIMENTO 2: O plasma seminal e sua influência sob as características espermáticas..................................................................... 57

5.2.1 Local................................................................................................................... 57

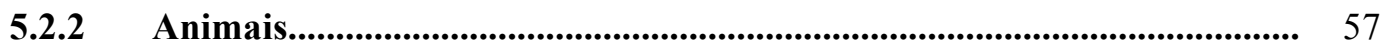

5.2.3 Coleta de sêmen suíno.............................................................................. 58 
5.2.4 Avaliação espermática........................................................................................ 58

5.2.5 Criopreservação seminal e tratamentos experimentais............................... 58

5.2.6 Obtenção de plasma seminal.............................................................................. 60

5.2.7 Descongelação e rearranjo dos tratamentos experimentais........................ 61

5.2.8 Análise computadorizada da cinética espermática - CASA....................... 61

5.2.9 Análises por citometria de fluxo.............................................................. 63

5.2.9.1 Avaliação simultânea da integridade das membranas plasmática e acrossomal e do potencial de membrana mitocondrial.................................... 64

5.2.9.2 Desordem lipídica da membrana plasmática................................................. 64

5.2.9.3 Lipoperoxidação dos lipídeos de membrana.................................................. 65

5.2.9.4 Detecção da fosforilação do aminoácido tirosina na superfície da membrana espermática........................................................................... 66

5.3 EXPERIMENTO 3: O plasma seminal e sua influência sobre e a fertilidade e prenhes de matrizes suinas..................................................... 67

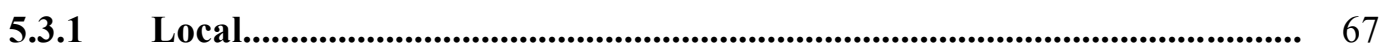

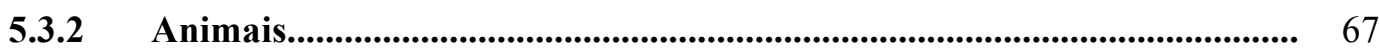

5.3.3 Coleta e análises iniciais do sêmen............................................................... 68

5.3.4 Criopreservação seminal e tratamentos experimentais............................... 68

5.3.5 Obtenção de plasma seminal...................................................................... 69

5.3.6 Descongelação e rearranjo dos tratamentos experimentais........................ 69

5.3.7 Preparação das marrãs e inseminações artificiais.......................................... 70

5.3.8 Abate, coleta e avaliação dos embriões suínos................................................ 72

5.4 ANÁLISE ESTATÍSTICA.............................................................. 75

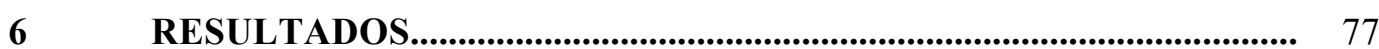

6.1 EXPERIMENTO 1: Validação da técnica de análise simultânea da integridade das membranas plasmática e acrossomal e do potencial de membrana mitocondrial espermática por citometria de fluxo.

6.2 EXPERIMENTO 2: O plasma seminal e sua influência sob as caracteristicas espermáticas................................................................. 78

6.2.1 Análise computadorizada da cinética espermática - CASA...................... 79

6.2.2 Análises por citometria de fluxo......................................................................... 81

6.2.2.1 Avaliação simultânea da integridade das membranas plasmática e acrossomal e do potencial de membrana mitocondrial................................. 81

6.2.2.2 Desordem lipídica da membrana plasmática................................................. 83

6.2.2.3 Lipoperoxidação dos lipídeos de membrana................................................... 84

6.2.2.4 Detecção da fosforilação do aminoácido tirosina na superfície da 
membrana espermática.

6.3 EXPERIMENTO 3: O plasma seminal e sua influência sobre a fertilidade e prenhes de matrizes suinas..................................................................... 86

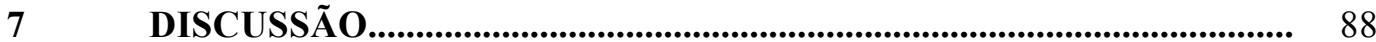

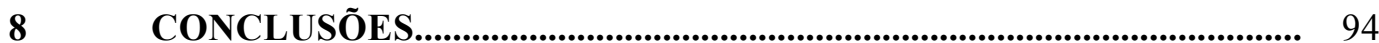

9 CONSIDERAÇÕES FINAIS...................................................................... 96

REFERÊNCIAS...................................................................................... 98 


\section{INTRODUÇÃO}

"O real não está na saida nem na chegada: ele se dispõe para a gente é no meio da travessia"

Grande Sentão Veredas

(Guimañàes Rosa. 1956) 


\section{INTRODUÇÃO}

O sêmen criopreservado de suíno é utilizado em baixa escala comercial (JOHNSON et al., 2000), sendo que menos de um por cento das inseminações artificiais realizadas no mundo, na suinocultura industrial, ocorre com a utilização de sêmen criopreservado (RODRÍGUEZ-GIL; ESTRADA, 2013), apesar de esta ser considerada a melhor biotecnologia para a conservação do sêmen suíno por longos períodos (YESTE, 2015). Além das vantagens de possibilitar o transporte de genéticas de alta qualidade e/ou das doses seminais sem restrições de tempo, possibilitando também a incorporação de testes para presença de patógenos, e consecutivamente, melhorando a biosseguridade (BAILEY et al., 2008) além da possibilidade de manutenção de banco de germoplasma (EGITO et al., 2002).

Essa baixa exploração do uso do sêmen congelado na suinocultura industrial é consequência dos danos estruturais e funcionais as membranas espermáticas, oxidação dos lipídeos e do material genético, alteração na estrutura e organização da membrana plasmática; danos que são inerente ao processo, e geram, por consequência, a diminuição do potencial fertilizante dessas células após a descongelação (JOHNSON et al., 2000; RATH et al., 2009) diminuindo o número de leitões por leitegada (JOHNSON et al., 2000).

As alterações geradas nas membranas espermáticas durante o processo de congelação e descongelação se assemelharem àquelas ocorridas durante o capacitação fisiológica (BAILEY; BILODEAU; CORMIER, 2000; WATSON, 2000). Além disso, os espermatozoides descongelados apresentam in vivo características semelhantes àqueles capacitados prematuramente (VADNAIS; ALTHOUSE, 2011), possuindo a habilidade de fertilizar o oócito (BAILEY; BILODEAU; CORMIER, 2000) mas com uma vida útil muito curta (BAILEY; BILODEAU; CORMIER, 2000; RODRIGUEZ-MARTINEZ, 2007) por não conseguirem formar o reservatório espermático, o que ocorre por não serem capazes de se aderir as células epiteliais da tuba uterina, devido ao aumento da fluidez do lipídeos da membrana plasmática (TIENTHAI; JOHANNISSON; RODRIGUEZ-MARTINEZ，2004; RODRIGUEZ-MARTINEZ, 2007). 
O sucesso da criopreservação seminal está intimamente correlacionado com a capacidade dos espermatozoides em sobreviverem aos processos de congelação e descongelação, mantendo sua integridade e funcionalidade (JOHNSON et al., 2000). A partir desse princípio, muitos estudos tem sido conduzidos a fim de melhorar a criopreservação do sêmen suíno, diminuindo os danos inerentes ao processo. Uma das alternativas que surgiu a alguns anos foi a adição de plasma seminal ao meio de descongelação seminal em várias espécies como bovinos (GARNER et al., 2001), equinos (DE ANDRADE et al., 2011, 2012), carneiros (ROVEGNO et al., 2013) e suínos (HERNÁNDEZ et al., 2007b; OKAZAKI et al., 2009, 2012; SARAVIA et al., 2009; FERNÁNDEZ-GAGO; DOMÍNGUEZ; MARTÍNEZPASTOR, 2013), e na grande maioria dos estudos foi observado o efeito benéfico que o plasma seminal tem sob os espermatozoides descongelados, o qual deve-se ao efeito que essa fração seminal tem de proteção contra o choque-frio (PURSEL; SCHULMAN; JOHNSON, 1973).

Em suínos tem se adotado o uso de frações específicas do ejaculado em substituição a fração total, e tem-se obtido resultados satisfatórios (SARAVIA et al., 2007). Tal fato tem ocorrido depois da descoberta que os espermatozoides derivados dos primeiros $10 \mathrm{~mL}$ da fração rica em espermatozoides (sperm-peak portion) são mais resistentes ao choque-frio, reação acrossomal prematura, possuem maior estabilidade de membrana plasmática o que, por fim, resulta em maior sobrevivência pós-descongelação (PEÑA et al., 2006; GARCÍA et al., 2009; SARAVIA et al., 2009; SARAVIA; WALLGREN; RODRÍGUEZ-MARTÍNEZ, 2010).

A adição do plasma seminal ao sêmen pós-descongelação tem a capacidade de reduzir a criocapacitação já que reduz o número de espermatozoides capacitados e/ou com acrossomo reagido em humanos, carneiros e suínos (HAN et al., 1990; VADNAIS et al., 2005; CROSS, 1993; GUTHRIE; MAXWELL; JOHNSON, 2000) e melhora a viabilidade (DE ANDRADE et al., 2011) e a motilidade dos espermatozoides (GUTHRIE; MAXWELL; JOHNSON, 2000). Fato este, que leva a obtenção de melhores resultados nos índices de prenhez em inseminações com sêmen criopreservado de carneiros (MAXWELL et al., 1999), ou seja, a criocapacitação e os efeitos deletérios da refrigeração podem ser revertidos com a adição de plasma seminal autólogo ao sêmen descongelado ou submetido a refrigeração (CROSS, 1993; BARRIOS et al., 2000; GUTHRIE; MAXWELL; JOHNSON, 2000). 
$\mathrm{Na}$ espécie suína, antes de se submeter o sêmen à congelação realiza-se a centrifugação. Este procedimento é necessário para promover o aumento da concentração dos espermatozoides, o qual é essencial para permitir o envasamento (CARVAJAL et al., 2004). Este plasma seminal retirado é então descartado mesmo sabendo que este ao ser adicionado ao sêmen pós-descongelação é capaz de reduzir os efeitos da criocapacitação (VADNAIS; ROBERTS, 2007).

Com o intuito aprimorar os estudos relacionados a melhora da congelabilidade do sêmen suíno, tanto no que diz respeito a qualidade in vitro dos espermatozoides, quanto a capacidade fertilizante dos mesmos pós descongelação, este estudo tem como objetivo avaliar os benefícios que a adição do plasma seminal pode trazer aos parâmetros espermáticos pósdescongelação assim como avaliar a capacidade fecundante desses espermatozoides. 


\section{REVISÃO DE LITERATURA}

"The great academic tradition of know mone and mone about less and less until know everything about nothing"

Alice em "Still Alice"

(Wash Westmoneland e Richand Glatzer. 2014) 


\section{REVISÃO DE LITRERATURA}

Nessa sessão serão abordados e revisados os temas que foram essenciais para a elaboração das hipóteses posteriormente apresentadas.

\subsection{OS ESPERMATOZOIDES SUÍNOS E A CRIOPRESERVAÇÃO SEMINAL}

Após o advento dos crioprotetores penetrantes, com a descoberta que o glicerol poderia ser utilizado em protocolos de criopreservação seminal com bons resultados (POLGE; SMITH; PARKES, 1949), essa biotecnologia passou a ser intensivamente estudada. Entretanto, por mais que a criobiologia tenha avançado muito nos últimos anos, ainda obtémse resultados muito similares aos obtidos por Polge (1951) na primeira criopreservação, registrada com sucesso, realizada com sêmen de galo, com aproximadamente $50 \%$ de sobrevivência pós-descongelação.

A criopreservação do sêmen suíno se faz importante no âmbito do transporte de genética associado a biosseguridade global (BAILEY et al., 2008). A criobiologia dos espermatozoides suínos vem sendo amplamente estudada desde sua primeira criopreservação em 1970 (PURSEL; JOHNSON; GERRITS, 1970), devido as características impares do ejaculado suíno quando comparado com o de outras espécies domésticas (JOHNSON et al., 2000).

A primeira particularidade do sêmen suíno é o grande volume ejaculado (200 - 400 mL), o que gera a necessidade de centrifugação do sêmen para concentração dos espermatozoides visando possibilitar o envase em palhetas finas $(0,25-0,5 \mathrm{~mL})$ para criopreservação seminal da fração total do ejaculado (CARVAJAL et al., 2004).

Por outro lado, a particular fisiologia da ejaculação dos machos suínos possibilita a diferenciação de frações especificas do ejaculado (RODRIGUEZ-MARTINEZ; WALLGREN, 2011). A primeira fração, denominada fração pré-espermática (PSF) 
corresponde a secreções das glândulas bulbouretrais e da próstata; a fração seminal seguinte, que é claramente diferenciada pela sua coloração esbranquiçada e aspecto mais espesso, e é denominada fração rica (FR) e possui a maior concentração de espermatozoides, fluido epididimário e pouca secreção das glândulas sexuais acessórias, os dez primeiros pulsos ejaculatórios dessa fração é denominada sperm-peak portion; a fração pós-espermática (PSRF) é composta por uma quantidade reduzida de células espermáticas embebidas em grande quantidade de plasma seminal (PS). A última fração do ejaculado suíno é representado pela fração gelatinosa oriunda das glândulas bulbouretrais, a qual possui a função, na monta natural, de tampão cervical para evitar o refluxo de sêmen pós cópula (RODRIGUEZMARTINEZ; WALLGREN, 2011).

A utilização a frações do ejaculado, mais especificamente a sperm-peak portion, é possível simplificar do método de criopreservação, não sendo necessária a etapa de centrifugação para a concentração dos espermatozoides (SARAVIA; WALLGREN; RODRÍGUEZ-MARTÍNEZ，2010; RODRIGUEZ-MARTINEZ; WALLGREN，2011). Os espermatozoides oriundos da sperm-peak portion são mais resistentes ao choque frio, reação acrossomal prematura e possuem uma maior estabilidade das membranas espermáticas (HOSSAIN et al., 2011a), o que gera um aumento na viabilidade espermática pósdescongelação (PEÑA et al., 2006; GARCÍA et al., 2009; SARAVIA et al., 2009; SARAVIA; WALLGREN; RODRÍGUEZ-MARTÍNEZ, 2010).

Por outro lado, a sperm-peak portion possui apenas a metade do número de espermatozoides da fração rica total, estando a outra metade presente no restante da fração rica (ZASIADCZYK et al., 2015). Com isso, a técnica de congelação do sêmen suíno com o uso da sperm-peak portion gera uma grande perda dos espermatozoides, e os seus benefícios podem não compensar as perdas geradas. Apesar do uso da fração rica total não ser comum para a criopreservação do sêmen suíno, é possível que a criopreservação dessa fração seminal gere benefícios pelo melhor aproveitamento dos espermatozoides do ejaculado. 


\subsubsection{As membranas espermáticas dos espermatozoides suínos e a criopreservação seminal}

A membrana plasmática é composta por uma bicamada de fosfolipídios, moléculas de colesterol e proteínas, respeitando o modelo de Mosaico Fluído proposto por Singer e Nicolson (1972). Os fosfolipídios de membrana possuem uma distribuição assimétrica em toda a bicamada, entretanto, normalmente, a fosfatidilserina e a fosfatidiletanolamina estão presentes no folheto citoplasmático da membrana enquanto a fosfatidilcolina $\mathrm{e}$ a esfingomielina localizam-se na porção extracelular da bicamada lipídica (GADELLA, 2008)

Os espermatozoides suínos possuem distintas particularidades em relação a composição da membrana plasmática, a qual, nessa espécie possui baixa concentração de fosfatidilcolina e altas porcentagens de fosfatidiletanolamina e esfingomielina. A composição dos ácidos graxos dos fosfolipídios de membrana determina o comportamento da fase de transição lipídica da membrana plasmática (JOHNSON et al., 2000). Os diferentes tipos de lipídeos de membrana possuem diferentes temperaturas de transição, o que faz com que com a diminuição da temperatura os lipídeos com a mesma sensibilidade se agrupam, as vezes irreversivelmente, formando balsas lipídicas (DE LEEUW et al., 1990) e como consequência alteram a seletividade e a permeabilidade da membrana plasmática (WATSON, 2000).

A membrana plasmática é considerada o primeiro sítio da ação deletéria do choque térmico (BAILEY et al., 2008; MEDRANO; WATSON; HOLT, 2012), o qual é responsável pelo efluxo de colesterol durante a criopreservação (WHITE, 1993). Além disso, a proporção colesterol: fosfolipídios da membrana plasmática dos espermatozoides de suínos é mais baixa $(0,12)$ (DE LEEUW et al., 1990) do que em outras espécies como bovinos $(0,38)$ e ovinos $(0,36)$ (DE LEEUW et al., 1990). Essas particularidades da membrana espermática de suínos induz uma maior formação das balsas lipídicas durante a refrigeração, o que torna os espermatozoides dessa espécie mais sensíveis ao choque frio (SIMPSON el al., 1987). A remoção do colesterol das membranas espermáticas aparentemente é o mediador da via de ativação da capacitação espermática, podendo culminar na reação acrossomal (SHADAN et al., 2004). 
A criopreservação espermática é responsável pela diminuição da atividade celular, até a sua total suspensão, a qual é recuperada após a descongelação (MAZUR, 1984). Entretanto, o metabolismo e funcionalidade celular não é recupera na grande maioria das células, em decorrência de danos letais e irreversíveis que ocorrem durante a congelação. Esses danos ocorrem principalmente devido a formação inadequada de cristais de gelo, estresse osmótico, choque frio, e descongelação (WATSON, 2000), sendo a membrana plasmática e a acrossomal externa são as estruturas espermáticas mais criosensíveis (SALAMON; MAXWELL, 1995).

\subsubsection{Fosforilação das proteínas}

Os espermatozoides maduros possuem sua particular idiossincrasia como células altamente especializadas. Estas são altamente compartimentalizadas, inativas quanto à transcrição gênica e inaptas a sintetizar novas proteínas. Desta maneira, percebe-se a grande importância das fosforilações das proteínas como forma de alterar suas funções, quando comparado a outros tipos celulares. Durante a fertilização, a função espermática é regulada por um sistema de sinais intracelulares que controlam fosforilações de proteínas. A fosforilação dos aminoácidos Serina/Treonina e da Tirosina ocorrem no espermatozoide, mas somente algumas proteínas fosforiladas foram identificadas. Embora a via do cAMPdependente da proteína quinase A desempenhe um papel central na função espermática e já tenha sido estudada em detalhes (VISCONTI; KOPFE, 1998), o conhecimento sobre as tirosina quinases e outras serina/treonina quinases permanece limitado (URNER; SAKKAS, 2003). Embora ocorra a fosforilação nos aminoácidos serina, treonina e na tirosina, a fosforilação do aminoácido tirosina é muito importante e deve ser considerada como a primeira, ou até mesmo a única a ser interpretada como um sinal de transdução em uma célula (NAZ; RAJESH, 2004). Os processos regulados pela fosforilação do aminoácido tirosina incluem a capacitação, hiperativação e a reação acrossomal, todas essas funções necessárias para que o espermatozoide alcance e se fusione ao oócito (VISCONTI et al., 2002). 
Em geral, a fosforilação do aminoácido tirosina é estudada pela identificação de proteínas com tirosina fosforilada, em populações espermáticas durante a capacitação e após a exposição a indutores da reação acrossomal, pela técnica de Western blot. Estes estudos levaram ao acúmulo de informações quanto ao peso molecular das proteínas com resíduos de tirosina fosforilado e quais papéis estas exercem durante a capacitação e a reação acrossomal. A fosforilação das proteínas também pode ser observada em um espermatozoide individualmente por imunocitoquímica, a qual revela a compartimentalização das proteínas fosforiladas e a heterogeneidade da população espermática (URNER; SAKKAS, 2003).

Deste modo, a fosforilação do aminoácido tirosina das proteínas espermáticas é um importante mecanismo intracelular de regulação da capacitação espermática de mamíferos, servindo como um significativo indicador da evolução deste processo. Este mecanismo parece ser promovido pela ação de fatores auxiliadores da capacitação como a proteína semelhante à albumina, o bicarbonato e o cálcio (VISCONTI et al., 1995; VISCONTI; KOPF, 1998; TARDIF et al., 2001).

\subsubsection{Hipermotilidade}

O processo de capacitação espermática também envolve mudanças no padrão de motilidade, o qual é denominado de hiperativação (YANAGIMACHI, 1994). Este padrão de movimento é necessário para a progressão do espermatozoide na tuba uterina, permitindo a liberação do espermatozoide do epitélio do istmo (DEMOTT; SUAREZ, 1992) e promovendo a motilidade necessária para a penetração da zona pelúcida (SUAREZ; PACEY, 2006). A hiperativação é caracterizada por movimentos vigorosos do flagelo, marcante deslocamento lateral da cabeça do espermatozoide e presença de uma trajetória não progressiva (SUAREZ; KATZ; OVERSTREET, 1983).

A hiperativação deve ter seu início em lugar e momento apropriado para que o espermatozoide consiga realizar a fertilização. Seria provável que este local estivesse com líquido folicular e presença do cumulus para então iniciar a hiperativação, mas há evidências 
in vivo de que estes fatores por si só não iniciam a hiperativação (HO; SUAREZ, 2001). Embora o líquido folicular seja encontrado na ampola da tuba uterina no momento da ovulação das porcas, somente $<1 \%$ permanece retido no lúmen da ampola (HANSEN et al., 1991).

A hiperativação tem sido considerada como parte no processo de capacitação; entretanto, há evidências (em bovinos) que a hiperativação é regulada separadamente ou por uma via de sinalização do $\mathrm{Ca}^{2+}$ divergente da que regula a reação acrossomal, tendo em vista, que a hiperativação ocorre mesmo quando é adicionado ao meio substâncias que bloqueiam a capacitação como o H-89, um inibidor da proteína quinase A (PKA) e o Rp-cAMPS, antagonista do cAMP (MARQUEZ; SUAREZ, 2004). Somando-se a estes achados, Colenbrander et al. (2001) descreveram que a porcentagem de células hiperativadas de uma determinada população de células com motilidade não teve mudanças quando induzidas a capacitação, concluindo que este movimento característico não pode ser usado na avaliação da capacitação.

O movimento característico apresentado pela célula espermática durante o fenômeno da hiperativação pode ser detectado pelas análises computadorizadas da motilidade (CASA Computer Assisted Sperm Analisys). Este padrão de movimento é representado pelo aumento do ALH (amplitude do deslocamento lateral da cabeça) e do VCL (velocidade curvilinear) (WHITE; AITKEN, 1989; BURKMAN, 1991). Schmidt e Kamp (2004) descreveram que os espermatozoides suínos podem ser considerados hiperativados quando apresentam ALH $>3,5$ $\mu \mathrm{m}$ e VCL $>97 \mu \mathrm{m} / \mathrm{s}$.

\subsubsection{Reação Acrossomal}

O oócito de todos os mamíferos eutérios é circundado por um revestimento glicoprotéico, a zona pelúcida, esta é circundada pelas células da granulosa oriundas do cumulus oophorus recém expandido (YANAGIMACHI, 1994). Antes de fertilizar o oócito, o 
espermatozoide deve passar pela zona pelúcida e, para isto acontecer, o espermatozoide tem que sofrer a reação acrossomal assim que se ligar a zona. A reação acrossomal é um evento irreversível de exocitose, caracterizado por um aumento repentino do influxo de $\mathrm{Ca}^{2+}$ para o interior da célula e fusão da membrana acrossomal externa com a membrana plasmática (GADELLA et al., 2001), deste modo, liberando as enzimas (hialuronidase, proacrosina, esterases, fosfolipase $A_{2}$, fosfatases ácidas, aril-fosfatases, $\beta$-N-acetil glucosaminidase, aril amidase e proteínas ácidas não específicas) responsáveis pela lise da zona pelúcida (BAZER; GEISERT; ZAVY, 1995).

\subsubsection{Mudanças semelhantes à capacitação (criocapacitação)}

A criopreservação do sêmen é uma importante ferramenta para a reprodução assistida, embora a fertilidade do espermatozoide criopreservado seja reduzida por danos, por vezes subletais e que não se encontram ainda elucidados por completo (BAILEY; BILODEAU; CORMIER, 2000).

Embora a base para explicar a menor fertilidade recaia no fato das amostras criopreservadas apresentarem uma menor motilidade, só a motilidade baixa não pode ser a única explicação, pois mesmo quando realizadas inseminações intra-cervicalmente com o mesmo número de espermatozoides móveis, a fertilidade do sêmen congelado é menor que no sêmen fresco (WATSON, 1995).

Pesquisas têm apontado que esta baixa fertilidade no sêmen criopreservado está associada às mudanças que se assemelham ao que ocorre durante a capacitação (criocapacitação) como a reorganização e aumento de fluidez da membrana plasmática e o influxo de cálcio para o interior da célula espermática (MAXWELL; JOHNSON, 1997; GREEN; WATSON, 2001).

Fuller e Whittingham (1996) observaram que quase todos os espermatozoides apresentavam mudanças semelhantes à capacitação (criocapacitação) após a descongelação. 
As mudanças foram reveladas pelo aumento na proporção de células apresentando fluorescência no padrão B (células capacitadas) quando coradas com a sonda clortetraciclina (CTC). Somando-se a este resultado, sabe-se que as células criocapacitadas estão aptas a culminar com a reação acrossomal ou, até mesmo, fertilizar oócitos in vitro (GILLAN; EVANS; MAXWELL, 1997; MAXWELL; JOHNSON, 1997) (PÉRES et al., 1996). Porém, estas células criocapacitadas não são capazes de se ligar ao epitélio da tuba uterina, para assim formarem o reservatório espermático. Deste modo, reduzindo o tempo de sobrevivência destas células no trato reprodutivo feminino (ABAD et al., 2007).

É importante salientar o que se encontra descrito no trabalho proposto por Neild et al. (2003). Estes autores ao associarem a CTC com a sonda Hoechst 33258, um corante impermeável a membrana plasmática e que se liga ao DNA das células com membrana plasmática lesada (não viáveis), observaram que as células consideradas não viáveis (positivo para o H3258) apresentavam todos os padrões exibidos pela técnica da CTC.

Estudos mais recentes realizados na espécie suína (GREEN; WATSON, 2001; BRAVO et al., 2005) tem demonstrado que apesar das células refrigeradas $\left(5^{\circ} \mathrm{C}\right)$ ou criopreservadas apresentarem como resultado final aspectos semelhantes a uma célula capacitada as vias intracelulares são distintas, tendo em vista, os diferentes padrões de fosforilação dos resíduos de tirosina.

Deste modo, conhecimentos sobre os processos que resultam/ou não na capacitação prematura do espermatozoide suíno durante a criopreservação são imprescindíveis para a obtenção de uma boa taxa de fertilidade, bem como dos mecanismos para prevenir ou atrasar estas mudanças.

\subsection{O PLASMA SEMINAL E SEU IMPACTO NA CRIOPRESERVAÇÃO SEMINAL}

O sêmen é um fluído oriundo da união das secreções de glândulas sexuais acessórias e reprodutivas, o qual pode ser dividido em duas frações: celular e acelular. Esta última é 
genericamente denominada de plasma seminal (PS), a qual é composta pela união dos fluídos da cabeça do epidídimo e das glândulas sexuais acessórias (RODRÍGUEZ-MARTÍNEZ et al., 2011). Vários componentes orgânicos e inorgânicos constituem o plasma seminal como aminoácidos, proteínas, íons, frutose, sorbitol, inositol, bicarbonato, substâncias antimicrobianas, lipídios e uma gama variada de substâncias hormonais (GARNER; HAFEZ, 2004).

O plasma seminal é uma mistura de secreções produzidas nos testículos, epidídimos e pelas glândulas sexuais acessórias, sendo importante em múltiplas funções que envolvem os eventos que precedem a fertilização. Existem vários componentes orgânicos e inorgânicos no plasma, como aminoácidos, proteínas, íons $\left(\mathrm{Na}^{+}, \mathrm{Cl}^{-}, \mathrm{Ca}^{2+}, \mathrm{Mg}^{2+}, \mathrm{K}^{+}\right.$, entre outros), bicarbonato, frutose, sorbitol, inositol, ergotionina, glicerilfosforilcolina, ácido cítrico, ácido ascórbico, lipídios, enzimas, antimicrobianos, imunoglobulinas e uma variedade de substâncias hormonais, todos em quantidades variadas (GARNER; HAFEZ, 2004).

O plasma seminal possui em sua constituição substâncias moduladoras da inflamação uterina, estas substâncias auxiliam na eliminação dos espermatozoides e na limpeza uterina. Além disso, durante a inflamação, algumas proteínas seminais protegem os espermatozoides viáveis, enquanto outras facilitam a fagocitose de espermatozoides danificados (ALGHAMDI; FOSTER; TROEDSSON, 2004). Prostaglandinas ( PGF $_{2 \alpha}$ e PGE) e estrógenos presentes no plasma seminal podem auxiliar no transporte do espermatozoide, assim como a ocitocina (KATILA, 2001).

Em geral, considera-se que a capacitação tem seu início com a remoção do plasma seminal com todas as suas substâncias (incluindo as chamadas substâncias decapacitantes), o que leva a uma reorganização da membrana plasmática e do metabolismo intracelular (COLENBRANDER et al., 2002). Por este motivo, foram realizadas diversas tentativas de purificação dos fatores presentes no plasma seminal. Os achados levaram a diferentes conclusões sobre a natureza destes fatores que podem ser lipídicas como o colesterol ou protéicas. As diversas substâncias atuariam no espermatozoide ligando-se aos receptores, estabilizando a membrana plasmática, ou limitando o influxo de cálcio (CROSS, 1993; EMILIOZZI; FENICHEL, 1997). 
Apesar de não se saber, exatamente, quais os fatores presentes no plasma seminal que sensibilizam ou promovem a resistência espermática, deve-se considerar a presença de proteínas seminais, que interajam com a membrana plasmática (MOORE; HALL; HIBBIT, 1976). Na espécie suína, Caballero et al., (2008) relatam que mais de 90\% das proteínas que constituem o plasma seminal são pertencentes a família da espermodesinas, as quais podem ser heparin-binding ou non-heparin-binding, sendo que a non-heparin-binding PSP-I e PSP-II correspondem $>50 \%$ das proteínas do plasma seminal. Estas proteínas agem cobrindo a superfície da célula espermática, atuando entre outras coisas, na estabilização da membrana acrossomal.

Os fluidos epididimários e seminal e as vesículas membranosas (epididiossomos e prostassomos) têm sido considerados como inibidores da capacitação por inserirem fatores decapacitantes na superfície espermática, os quais previnem que o espermatozoide responda adequadamente ao estímulo da capacitação. Para a fertilização in vitro (FIV), o espermatozoide é lavado através de um meio com diferentes gradientes de densidade e colocado em um meio semelhante ao fluido da tuba uterina, estes procedimentos com o intuito de mimetizar a retirada dos fatores decapacitantes que ocorrem naturalmente no trato reprodutivo da fêmea para então ocorrer à fertilização (SOSTARIC et al., 2008).

O plasma seminal contém mecanismos antioxidantes que evitam os efeitos nocivos das espécies reativas de oxigênio (POTTS; NOTARIANNI; JEFFERIES, 2000). O sêmen contém uma alta concentração de ascorbato, urato e grupos tiol, além de uma pequena quantia de glutationa (GSH) e $\alpha$-tocoferol (OCHSENDORF et al., 1998). E mais as enzimas antioxidantes catalase, superoxido-dismutase (SOD), glutationa peroxidase (GPX), e glutationa redutase (GRD) (SANOCKA et al., 1996). Sendo ainda encontradas, apesar de quase irrisórias, concentrações de antioxidantes no próprio espermatozoide (ALVAREZ; STOREY, 1989).

A existência de diferentes componentes no plasma seminal, relacionados com a capacidade do espermatozoide apresentar melhora na motilidade após a refrigeração ou congelação, vem sendo estudada. Barrios et al. (2000), trabalhando com carneiros, notaram a possibilidade de reversão dos efeitos do "choque frio" pela adição de plasma seminal autólogo, após reaquecimento da amostra refrigerada. Estes autores atribuíram até $50 \%$ dos 
efeitos de reversão dos danos a uma faixa de proteínas com aproximadamente $20 \mathrm{kDa}$ presentes no plasma seminal.

É importante salientar que antes de submeter o sêmen suíno à congelação realiza-se a centrifugação. Este procedimento é necessário para a retirada da maior parte do plasma seminal, assim promovendo o aumento da concentração dos espermatozoides, o qual é essencial para permitir o envasamento (CARVAJAL et al., 2004).

Ressalta-se que a adição do plasma seminal ao sêmen pós-descongelação tem a capacidade de reduzir a criocapacitação já que reduz o número de espermatozoides capacitados e/ou com acrossomo reagido em humanos, carneiros e suínos (HAN et al., 1990; VADNAIS et al., 2005; CROSS, 1993; GUTHRIE; MAXWELL; JOHNSON, 2000) e leva a uma melhora na viabilidade e motilidade dos espermatozoides (GUTHRIE; MAXWELL; JOHNSON, 2000). A melhora destas características são refletidas na obtenção de melhores resultados nos índices de prenhes em inseminações com sêmen criopreservado de carneiros (MAXWELL et al., 1999), ou seja, a criocapacitação e os efeitos deletérios da refrigeração podem ser revertidos com a adição de plasma seminal autólogo ao sêmen descongelado ou submetido à refrigeração (CROSS, 1993; BARRIOS et al., 2000; GUTHRIE; MAXWELL; JOHNSON, 2000). 


\section{HIPÓTESES}

"Que mistério, a Natureza! E como ainda está atrasada a ciência dos homens!"

Dona Benta em "O poço do Visconde"

(Monteiro Lobato. 1937) 


\section{HIPÓTESES}

Após o estudo da literatura apresentada, e em conjunto com a ausência de algumas informações e trabalhos científicos em temas específicos, foram elaboradas as seguintes hipóteses:

1. A avaliação simultânea da integridade da membrana plasmática e acrossomal e potencial de membrana mitocondrial é possível de se realizar por citometria de fluxo com a associação das sondas fluorescente Hoechst 33342, iodeto de propídeo, PSAFITC e JC-1;

2. A adição de plasma seminal oriundo da fração rica total do ejaculado suíno é capaz de reverter os efeitos da criopreservação, no que diz respeito as alterações nos padrões de motilidade, nas alterações das membranas e lipoperoxidação da membrana;

3. O plasma seminal oriundo da fração rica total do ejaculado suíno adicionado ao sêmen descongelado de suíno é capaz de aumentar a taxa de prenhez e de fertilidade de fêmeas suínas. 


\section{OBJETIVOS}

"Foi o tempo que dedicastes à tua rosa que a fez tão impontante"

O Pequeno Principe em "Le Petit Prince"

(Antoine de Saint-Exupéry. 1943) 


\section{OBJETIVOS}

Baseado nos conhecimentos previamente expostos e nas hipóteses formuladas, o presente trabalho foi desenvolvido a fim de atingir os seguintes objetivos:

- Validar uma técnica de citômetria de fluxo capaz de avaliar simultaneamente a integridade das membranas plasmática e acrosomal e potencial de membrana mitocondrial através da associação das sondas fluorescentes Hoechst 33342, iodeto de propídeo, PSA-FITC e JC-1;

- Avaliar o efeito da ação de plasma seminal oriundo da fração rica do ejaculado suíno ao sêmen descongelado sob as alterações geradas nas membranas espermáticas, na cinética espermática e na lipoperoxidação dos lipídeos de membrana;

- Verificar se o plasma seminal oriundo da fração rica do ejaculado suíno é capaz de aumentar as taxas de fertilidade e prenhes do sêmen descongelado. 


\section{MATERIAL E MÉTODOS}

"Ninguém é suficientemente perfeito. que não possa aprender com o outro e. ninguém é totalmente destituido de valones que não possa ensinar algo ao seu irmão." 


\section{MATERIAL E MÉTODOS}

Nessa sessão serão apresentadas as metodologias empregadas, no presente trabalho, que auxiliam a alcançar os objetivos previamente descritos.

5.1 EXPERIMENTO 1: Validação da técnica de análise simultânea da integridade das membranas plasmática e acrossomal e potencial de membrana mitocondrial espermática por citometria de fluxo.

\subsubsection{Local}

As análises experimentais foram realizadas no Laboratório de Produção Animal da Faculdade de e Ciências Agropecuárias e Florestais, no Centro de excelência de Biotecnologia de Reprodução (CEBIOR) e no Núcleo científico e tecnológico de biorecursos (BIOREN) todos pertencentes a Universidade de La Frontera, Temuco - Chile.

\subsubsection{Animais}

Para a execução desse experimento, foram utilizados nove cachaços híbridos, os quais foram alojados nas dependências do Campo experimental Maquehue da Universidad de La Frontera, Temuco - Chile, em baias individuais de $6 \mathrm{~m}^{2}$ providas de comedouros manuais e bebedouros do tipo chupeta. Os animais foram arraçoados durante todo período experimental com ração peletizada comercial duas vezes ao dia, atendendo as exigências nutricionais estipuladas por Rostagno (2005). O período experimental se estendeu de março a junho de 2015. 


\subsubsection{Coleta de sêmen suíno}

As coletas de sêmen foram realizadas pelo método da mão-enluvada, sendo coletada apenas a fração rica (FR) do ejaculado. Anteriormente a cada coleta, o animal foi submetido à lavagem do divertículo prepucial, com anterior esgotamento do mesmo. A fração oriunda da glândula bulbouretral (fração gelatinosa) foi devidamente separada com auxílio de papel filtro fixado sobre a parte superior do copo de coleta o qual era previamente aquecido e mantido durante toda a coleta em recipiente isotérmico a $38^{\circ} \mathrm{C}$.

\subsubsection{Avaliação Espermática}

O sêmen in natura foi avaliado quanto ao volume, concentração, com auxílio de um hematocitômetro (câmara de Neubauer), e características da motilidade com o software Sperm Class Analyser (SCA - Microptics Barcelona, Espanha), através da captura de imagens simultâneas por uma câmera acoplada a um microscópio equipado com contraste de fase (Nikon, Modelo Eclipse Ni-U 80i) e a morfologia espermática foi avaliada por contraste de interferência diferencial (DIC). Somente ejaculados com motilidade total acima de $75 \%$ e alterações morfológicas abaixo de $20 \%$ foram submetidos à criopreservação e obtenção de plasma seminal. 


\subsubsection{Citometria de fluxo}

As análises foram realizadas com auxílio do citômetro de fluxo BD FACSAria I (Becton Dickinson, San Jose, CA, USA) comandado pelo software BD FACSDiva 6.0. As células foram simultaneamente excitadas por um laser de argônio de $488 \mathrm{~nm}$ e por um laser ultravioleta de $375 \mathrm{~nm}$. Foram analisadas 10.000 células por amostras, as quais foram analisadas com uma taxa de aquisição de 600 a 1000 eventos/ segundo. Para a detecção dos sinais luminosos de cada fluoróforo utilizado foram utilizados os seguintes tubos fotomultiplicadores (PMT): Hoechst 33342 (H342): band pass 450/40 nm; iodeto de propídeo (IP): long pass 655 nm e band pass 695/40; aglutinina de Pisum sativum conjugada com FITC (PSA-FITC): long pass $502 \mathrm{~nm}$ e band pass 530/30 nm; JC-1 (5,5',6,6'-tetra- chloro-1,1',3,3'iodeto de carbocianato de tetraetilbenzomidazol): long pass $556 \mathrm{~nm}$ e band pass 585/42 nm.

\subsubsection{Compensação manual do spectral overlap entre os fluoróforos}

A compensação do spectral overlap é uma prática essencial em citometria de fluxo quando se associam dois ou mais corantes e/ou sondas, ela é realizada a fim de descontar a sobreposição dos sinais luminosos para um mesmo espectro. A técnica que validamos no presente experimento, compreende a associação de quatro sondas fluorescente, com isso fezse necessária a realização da compensação manual (figura 1). Para tal, realizamos controles positivos e negativos para cada fluoróforo utilizado. Os controles e como foram realizados, estão descritos na tabela 1: 
Tabela 1 - Controles de citometria de fluxo para a compensação da coloração quádrupla de avaliação da integridade das membranas plasmática e acrossomal e potencial de membrana mitocondrial.

\begin{tabular}{|c|c|c|c|c|}
\hline Tubo & Característica Avaliada & Sonda Fluorescente & Controle & $\begin{array}{c}\text { Método/Amostra } \\
\text { utilizada }\end{array}$ \\
\hline $\begin{array}{c}\text { Auto- } \\
\text { Fluorescencia }^{1}\end{array}$ & - & - & - & $\begin{array}{c}\text { Amostra in-natura sem } \\
\text { adição de corantes }\end{array}$ \\
\hline H342 & Contra-corante & $\begin{array}{l}\text { Hoechst } 33342 \\
(1,17 \mu \mathrm{g} / \mathrm{mL})^{*}\end{array}$ & - & Amostra in-natura \\
\hline PI - & $\begin{array}{c}\text { Membrana plasmática - } \\
\text { íntegra }\end{array}$ & $\begin{array}{l}\text { Iodeto de Propídeo } \\
\qquad(10 \mu \mathrm{g} / \mathrm{mL})^{*}\end{array}$ & Negativo & Amostra in-natura \\
\hline $\mathbf{P I}+$ & $\begin{array}{c}\text { Membrana plasmática - } \\
\text { lesionada }\end{array}$ & $\begin{array}{l}\text { Iodeto de Propídeo } \\
\qquad(10 \mu \mathrm{g} / \mathrm{mL})^{*}\end{array}$ & Positivo & Amostra "Flash-frozen" \\
\hline PSA - & $\begin{array}{c}\text { Membrana acrossomal - } \\
\text { íntegra }\end{array}$ & $\begin{array}{l}\text { FITC-PSA } \\
(100 \mu \mathrm{g} / \mathrm{mL})\end{array}$ & Negativo & Amostra in-natura \\
\hline PSA + & $\begin{array}{c}\text { Membrana acrossomal - } \\
\text { reacionada }\end{array}$ & $\begin{array}{c}\text { FITC-PSA } \\
(13,33 \mu \mathrm{g} / \mathrm{mL})^{*}\end{array}$ & Positivo & Amostra "Flash-frozen" \\
\hline $\mathrm{JC}-1+$ & $\begin{array}{l}\text { Potencial de membrana } \\
\text { mitocondrial - alto }\end{array}$ & $\mathrm{JC}-1(4,08 \mu \mathrm{M})^{*}$ & Positivo & Amostra in-natura \\
\hline JC-1 - & $\begin{array}{l}\text { Potencial de membrana } \\
\text { mitocondrial - baixo }\end{array}$ & $\mathrm{JC}-1(4,08 \mu \mathrm{M})^{*}$ & Negativo & $\begin{array}{l}\text { Amostra induzida com } \\
\mathrm{CCCP}^{3}\end{array}$ \\
\hline
\end{tabular}

Fonte (TORRES, M. A., 2015)

${ }^{1}$ Controle de autofluorescência utilizado para o ajuste de voltagens. ${ }^{2}$ "flash-frozen" esse método consiste em três ciclos de congelação rápida e descongelação lenta, com intuído de lesionar todas as membranas celulares. ${ }^{3}$ CCCP (Cianeto carbonato de m-clorofenilhidrazona - $10 \mu \mathrm{M}$ ), composto descarreador de elétrons. ${ }^{*}$ Todas as amostras foram diluídas para $5 \times 10^{6}$ espermatozoides/ $\mathrm{mL}$ em $150 \mu \mathrm{L}$ de meio TALP. 
As amostras induzidas com CCCP (Cianeto carbonato de m-clorofenilhidrazona - 10 $\mu \mathrm{M}$ ) foram incubadas por 5 minutos a $37^{\circ} \mathrm{C}$, após esse período foram centrifugadas a $500 \times \mathrm{g}$ por 5 minutos, o sobrenadante foi retirado e o pellet de espermatozoides foi suspendido em $150 \mu \mathrm{L}$ de TALP. Após a adição das sondas fluorescentes, descritas na tabela 1, procedeu-se a incubação por 10 minutos a $37^{\circ} \mathrm{C}$. Posteriormente, as amostras foram diluídas em $150 \mu \mathrm{L}$ de TALP a fim de obter uma concentração de $2,5 \times 10^{6}$ espermatozoides/ $\mathrm{mL}$ no momento da análise.

Figura 1- Controles dos fluoróforos utilizados para a compensação manual em citometria de fluxo da coloração quádrupla dos espermatozoides suínos

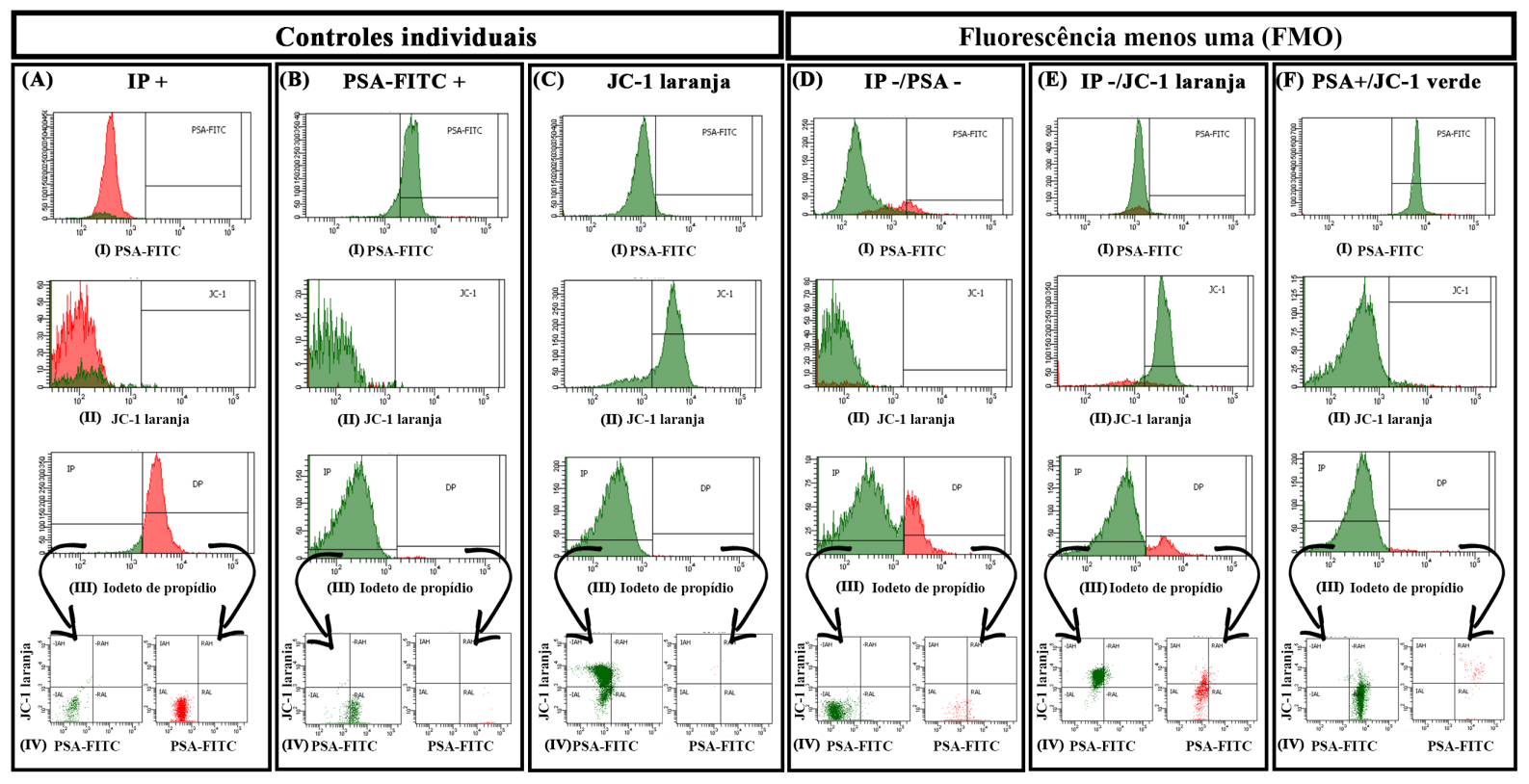

Fonte: (TORRES, M. A., 2015) 
A) Amostras submetidas a três ciclos de congelação rápida e descongelação lenta (flash freezing - FF) para indução de danos na membrana plasmática, e corada com iodeto de propídeo (IP+). (I) Histograma mostrando a ausência de coloração pelo PSA-FITC; (II) histograma mostrando a ausência de fluorescência do JC-1 laranja; (III) histograma mostrando os gates das populações IP (membrana plasmática integra) e DP (membrana plasmática lesionada), e predomínio da população no gate DP; (IV) dois gráficos tipo dot plot para a avaliação do potencial de membrana mitocondrial $(\Delta \psi \mathrm{m}$ - eixo y) e integridade acrossomal (eixo x); o dot plot representado pelo população em verde tem sua origem do gate IP do gráfico II, enquanto o em vermelho é originado a partir do gate PL; a população representada nesses gráficos correspondem as mesma características apresentadas nos histogramas anteriores. B) Amostras submetidas a FF, como descrito anteriormente, para indução de lesão acrossomal, e coradas com aglutinina de Psium stivum conjugada com FITC (PSA-FITC positivo). (I) Histograma mostrando fluorescência positive para PSA-FITC; (II) histograma mostrando a ausência de fluorescência para o JC-1 laranja; (III) histograma mostrando os gates IP e DP, e a população espermática concentrada no gate IP; (IV) as populações representadas nesses gráficos condizem com as características apresentadas nos histogramas anteriores. (C) Amostra de espermatozoides viáveis com alto $\Delta \psi \mathrm{m}$ e corados com JC-1 (fluorescência laranja dos J-agregados). (I) Histograma mostrando a ausência defluorescência para PSA-FITC; (II) histograma mostrando a fluorescência laranja do JC-1; (III) histograma mostrando os gates IP e DP, e a população concentrada no gate IP; (IV) as populações representadas nesses gráficos são condizentes com as características apresentados dos histogramas anteriores. (D) Amostra de espermatozoides viáveis corada simultaneamente com IP e PSA-FITC, para separar o spectral overlap entre os fluoróforos utilizados. (I) Histograma mostrando fluorescência negativa para PSA-FITC; (II) histograma mostrando ausência de fluorescência laranja do JC-1; (III) histograma mostrando as populações espermáticas nos gates IP e DP; (IV) as populações espermáticas representadas nesses gráficos correspondem as características apresentas no histogramas anteriores. (E) Amostra de espermatozoides viáveis corada simultaneamente com IP e JC-1, para separar o spectral overlap entre a fluorescência vermelha do IP e laranja do JC-1 (J-agregados).

(I) Histograma mostrando a ausência de fluorescência do PSA-FITC; (II) histograma mostrando a fluorescência laranja do JC-1; (III) histograma mostrando os gates IP e DP, e predomínio da população no gate IP; (IV) as populações representadas nesses gráficos correspondem as características anteriormente avaliadas nos histogramas anteriores. (F) Amostras submetidas a FF, como descrito anteriormente, com baixo $\Delta \psi \mathrm{m}$ e membrana acrossomal lesionada, corada simultaneamente com PSA-FITC e JC-1, para separar spectral overlap do PSA-FITC e da fluorescência laranja (J-agregados) e verde (J-monômeros) do JC-1. I) Histograma mostrando fluorescência positiva para o PSA-FITC; (II) histograma mostrando ausência de fluorescência laranja para o JC1; (III) histograma mostrando os gates IP e DP; (IV) as populações representadas nesses gráficos correspondem as características anteriormente analisadas nos histogramas. IAH: acrossoma íntegro e alto $\Delta \psi \mathrm{m}$; IAL: acrossoma íntegro e baixo $\Delta \psi \mathrm{m}$; RAH: acrossoma lesionado e alto $\Delta \psi \mathrm{m}$; RAL: acrossoma lesionado e baixo $\Delta \psi \mathrm{m}$.

Foram realizados também os controles FMO (fluorescência menos um) que consistem em combinações dos fluorocromos utilizados menos um destes, para os quais foram utilizadas as sondas PI, PSA-FITC e JC-1, sendo estas combinadas aos pares, e todas as combinações adicionadas. Os controles FMO tem por objetivo melhorar a compensação quando se ocuparam associações de três corantes ou mais combinações, com intuito de considerar, durante o processo de compensação manual, a interferência que as sodas podem gerar entre elas. 


\subsubsection{Tratamentos experimentais}

As amostras de sêmen in-natura foram divididas em duas alíquotas: uma foi mantida diluída e viável a $37^{\circ} \mathrm{C}$ até o momento das análises, a qual foi denominada in-natura; a outra foi submetida a três ciclos de congelação rápida e descongelação (flash frozen) lenta para induzir lesão das membranas plasmática e acrossomal e alterar a função mitocondrial. Cinco tratamentos experimentais foram preparados a partir de taxas de diluição de amostra in-natura : amostra flash frozen, a saber: 100 : 0 (T100), 75 : 25 (T75), 50 : 50 (T50), $25: 75$ (T25) e 0 : $100(\mathrm{~T} 0)$.

\subsubsection{Análise computadorizada da cinética espermática - CASA}

As amostras foram diluídas em meio Tyrode's albumina lactato piruvato (TALP, BAVISTER; LORRAINE, 1983) a concentração de 25 × $10^{6}$ espermatozoides/ mL com auxílio de um Hemocitômetro de Neubauer. O sêmen diluído foi analisado quando a motilidade espermática total (MT) através do software Sperm Class Analyzer (SCA Microptics ${ }^{\circledR}$ - Barcelona/Spain), os cinco melhores campos foram avaliados.

\subsubsection{Validação da técnica de coloração quadrupla dos espermatozoides suínos}

Para as análises em citometria de fluxo foram utilizadas amostras de $150 \mu \mathrm{L}$ com $5 \mathrm{x}$ $10^{6}$ espermatozoides $/ \mathrm{mL}$. A quádrupla coloração por citometria de fluxo foi realizada através da associação de quatro sondas fluorescentes a saber: PI $(100 \mu \mathrm{g} / \mathrm{mL})$ com intuito de 
classificar as células com membrana plasmática lesionada, PSA-FITC (13.3 $\mu \mathrm{g} / \mathrm{mL})$ para identificar as lesões acrossomais, e JC-1 $(4.08 \mu \mathrm{M})$ para marcar o potencial de membrana mitocondrial. Essa combinação de corantes foi associada com uma sonda marcadora de DNA, o H342, o qual é capaz de passar pela seletividade de membrana. Essa sonda foi utilizada visando a exclusão de partículas anucledas das análise. Após a adição de todas as sondas as amostras foram incubadas a $37^{\circ} \mathrm{C}$ por 10 minutos, então diluídas em $150 \mu \mathrm{L}$ de TALP para que no momento da análise estivessem em uma concentração de $2,5 \times 10^{6}$ espermatozoides $/ \mathrm{mL}$. Os espermatozoides foram classificados em oito categorias como previamente descrito em microscopia de epiflorescencia por Celeghini et al., e De Andrade et al (figura 2).

Figura 2 - Representação do template de análise dos espermatozoides suínos por coloração quádrupla

(A)

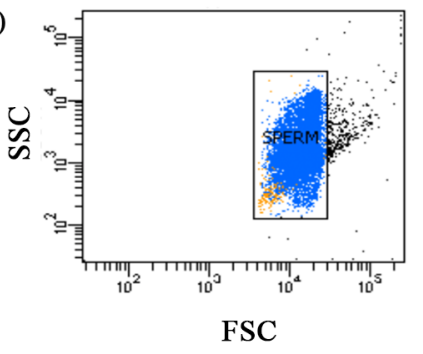

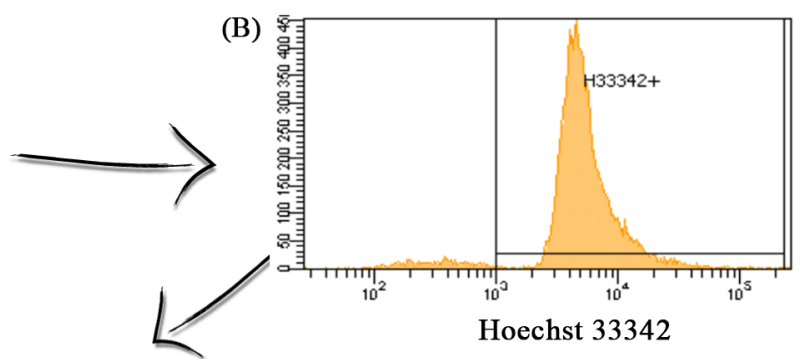

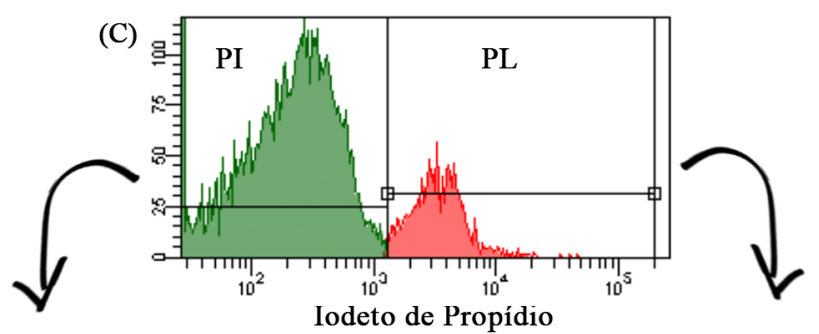

(D) Dot plot a partir do gate PI gate

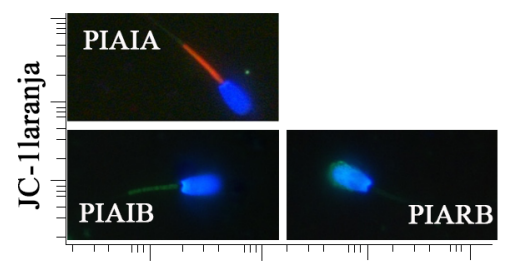

PSA - FITC

(E) Dot plot a partir do gate PL gate

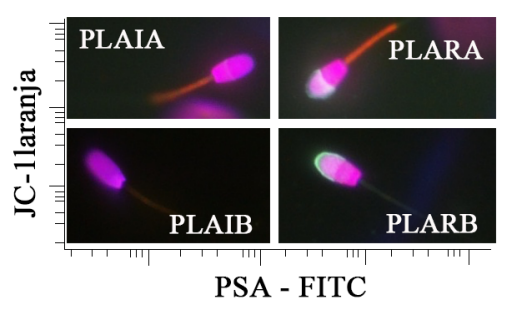

Fonte (TORRES, M. A., 2015) 
A) Seleção da população esperada dos espermatozoides por tamanho (FSC) e complexidade interna (SSC); B) Exclusão dos debris celulares, da população pré-selecionada do gráfico A, somente a população positiva para Hoechst 33342 será analisada; C) Identificação e diferenciação das populações espermática com membrana plasmática íntegra (PI; iodeto de propídeo negativo) e lesionada (PL; iodeto de propídeo positivo); D) Gráfico tipo dot plot para análise do potencial de membrana mitocondrial (eixo y) e da integridade acrossomal (eixo x) da população espermática oriunda do gate PI, e a representação por fotomicroscopia das quatro populações celulares encontradas; E) Gráfico tipo dot plot para análise do potencial de membrana mitocondrial (eixo y) e da integridade acrossomal (eixo $\mathrm{x}$ ) da população espermática oriunda do gate $\mathrm{PL}$, e a representação por fotomicroscopia das quatro populações celulares encontradas.

5.2 EXPERIMENTO 2: O plasma seminal e sua influência sob as características espermáticas.

\subsubsection{Local}

As análises experimentais foram realizadas no Laboratório de Andrologia e Tecnologia de Embriões Suínos (LATES) pertencente ao Núcleo de Pesquisa em Suínos da Faculdade de Medicina Veterinária e Zootecnia, e no Laboratório de Morfofisiologia Molecular e Desenvolvimento (LMMD) da Faculdade de Zootecnia e Engenharia de Alimentos, ambos localizados no campus administrativo de Pirassununga pertencente a Universidade de São Paulo.

\subsubsection{Animais}

Foram utilizados seis machos suínos adultos de linhagem híbrida comercial os quais foram alojados nas dependências do Laboratório de Pesquisa em Suínos pertencente ao 
Núcleo de Pesquisa em Suínos da Faculdade de Medicina Veterinária e Zootecnia da Universidade de São Paulo em baias individuais de $6 \mathrm{~m}^{2}$ providas de comedouros manuais e bebedouros do tipo chupeta. Os animais foram arraçoados durante todo período experimental com ração peletizada comercial duas vezes ao dia, atendendo as exigências nutricionais estipuladas por Rostagno (2005). O período experimental se estendeu de março a junho de 2015.

\subsubsection{Coleta de sêmen suíno}

Idem item 5.1.3.

\subsubsection{Avaliação Espermática}

Idem item 5.1.4.

\subsubsection{Criopreservação seminal e tratamentos experimentais}

Depois de realizadas as análises iniciais do sêmen, este foi dividido igualmente entre os tratamentos, a saber: controle (não centrifugado - CON), centrifugado suspendido em próprio plasma seminal (CPP) e congelado sem plasma seminal (CSP). Após a centrifugação (500 x g/10 min), os sedimentos obtidos de CPP foram cuidadosamente suspendidos em seu 
próprio plasma seminal e para CSP, o sobrenadante foi retirado, por aspiração, e reservado para obtenção do plasma seminal autólogo (ver item 5.2.6), sendo separados do sedimento, o qual foi então suspendido em diluente de congelação em uma proporção 1:1. Todos os tratamentos foram diluídos em diluentes de criopreservação (Botu-Sui ${ }^{\circledR}$ - Biotech-BotucatuLtda/ME, Botucatu, Brasil). a fim de obter uma concentração final de $300 \times 10^{6}$ espermatozoides/mL, após contagem espermática em hemocitometro de Neubauer. O sêmen diluído foi envasado em palhetas de 0,5 mL (IMV Internacional, St. Paul, Minesota, USA) (figura 3) e submetidos à congelação.

A criopreservação do sêmen foi realizada utilizando um sistema automático (TK $3000^{\circledR}$ compacta, TK Tecnologia em Congelação Ltda, Uberaba, Brasil), composto por um aparelho programável, equipado com porta-palhetas, compartimento de refrigeração e caixa térmica para nitrogênio líquido. Para a refrigeração, as palhetas foram colocadas no portapalhetas, acondicionado ao compartimento de refrigeração, obedecendo uma curva de refrigeração de $-0,5^{\circ} \mathrm{C} /$ minuto até $5^{\circ} \mathrm{C}$. Decorrido este período o porta-palhetas foi removido para a caixa térmica contendo nitrogênio líquido na qual a curva de congelação foi realizada a uma taxa de $-20^{\circ} \mathrm{C} /$ minuto de $5^{\circ} \mathrm{C}$ até $-120^{\circ} \mathrm{C}$. Após a curva de congelação as palhetas foram removidas do porta-palhetas e imersas em nitrogênio líquido $\left(-196^{\circ} \mathrm{C}\right)$. Por fim, as palhetas foram raqueadas e armazenadas em botijões criogênicos.

Figura 3 - Preparação e envase do sêmen suíno diluído em diluente de criopreservação.
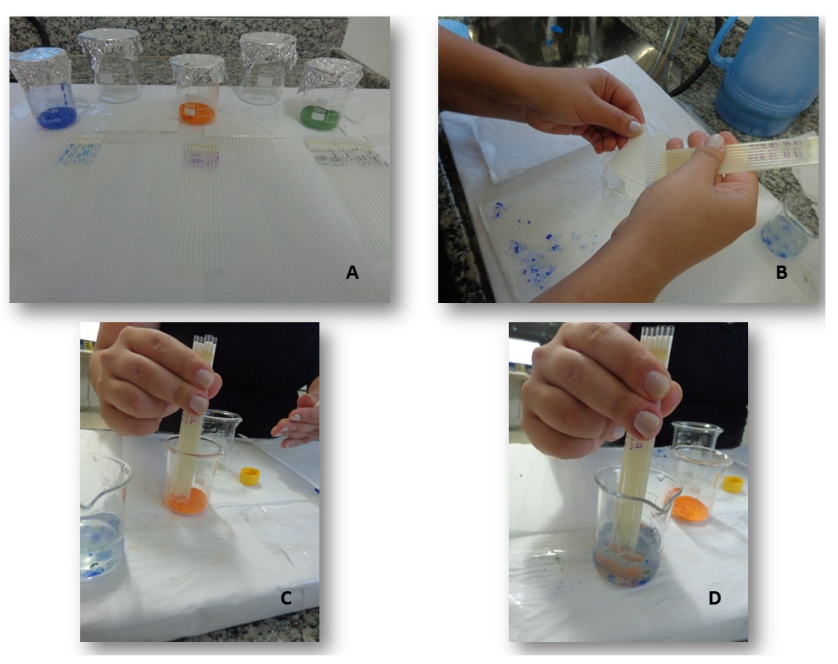
Fonte (TORRES, M. A., 2015)

A) Material utilizado para o envase do sêmen em palhetas de $0,5 \mathrm{~mL}$. B) Retirada do excesso de sêmen das palhetas. C e D) Vedação das palhetas com álcool polivinílico.

\subsubsection{Obtenção de plasma seminal}

O sobrenadante oriundo da centrifugação do tratamento CSP (figura 4A) foi transferido para um tubo de centrifugação de $50 \mathrm{~mL}$ e centrifugado novamente a uma força de $2500 \times \mathrm{g}$ por 30 minutos, decorrido esse tempo o sobrenadante foi retirado por aspiração (figura 4B) e acondicionado no compartimento superior do sistema de filtração a vácuo provido de uma membrana de filtração de 0,22 $\mu \mathrm{m}$ (TPP - Suíça) acoplado a uma bomba de vácuo (figura $4 \mathrm{C}$ ), o filtrado foi acondicionado em tubos criogênicos de $5 \mathrm{~mL}$ em freezer $80^{\circ} \mathrm{C}$ até o momento do uso.

Figura 4 - Obtenção de plasma seminal autólogo.
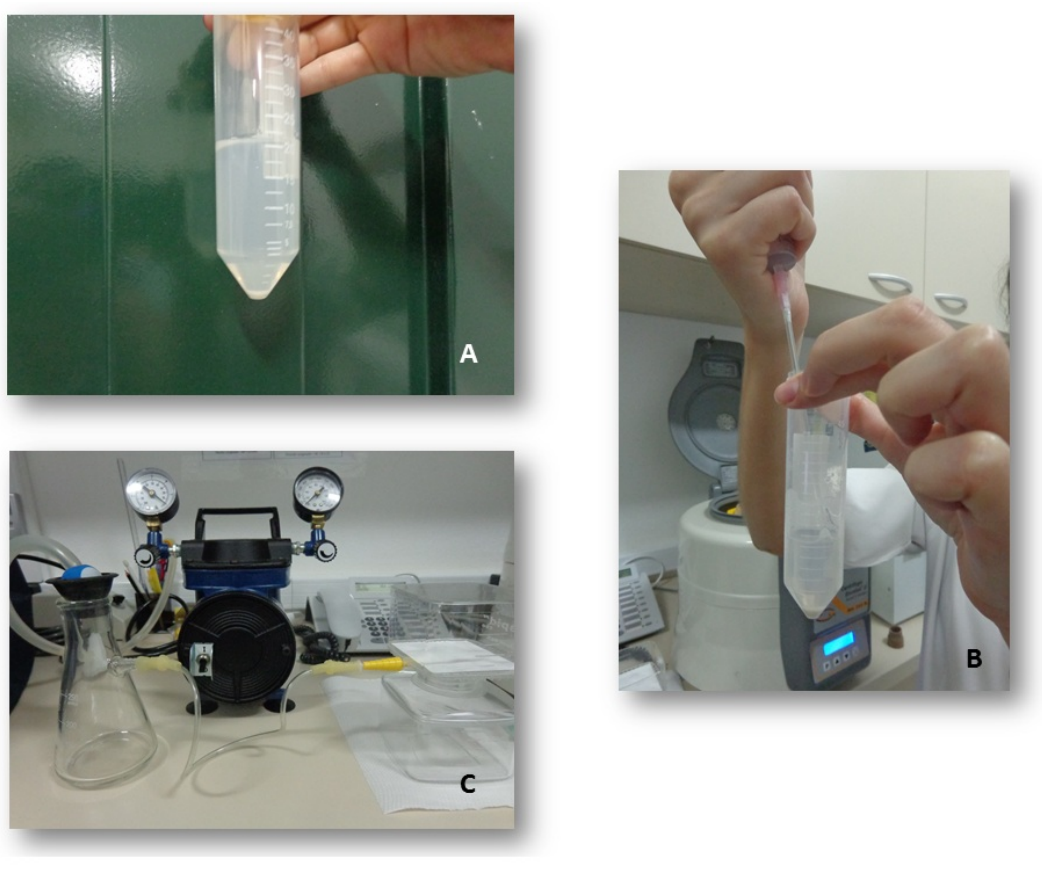
Fonte (TORRES, M. A., 2015)

A) Separação do pellet de espermatozoides e do sobrenadante (plasma seminal) através do processo de centrifugação. B) Retirado do plasma seminal por aspiração, após a separação por centrifugação. C) Sistema de filtração à vácuo para obtenção do plasma seminal livre de espermatozoides, o sistema é composto por uma bomba de vácuo, um kitassato com anel de vedação entre a tubulação e a vidraria, e um filtro à vácuo (TPP Suíça) com membrana de $0,22 \mu \mathrm{m}$.

\subsubsection{Descongelação e rearranjo dos tratamentos experimentais}

As palhetas foram descongeladas em banho-Maria a $37^{\circ} \mathrm{C}$ por 30 segundos. Por partida, foram descongeladas duas palhetas do grupo CON, CPP e CSP. Para esses grupos, o sêmen descongelado foi diluído, no mesmo diluente utilizado para a criopreservação. Desta mesma partida, outras duas palhetas do grupo CSP foram descongeladas e diluídas a concentração de $25 \times 10^{6}$ espermatozoides $/ \mathrm{mL}$ com diluidor Botu-Sui ${ }^{\circledR}$ contendo $10 \%$ de plasma seminal (v/v) dando origem ao grupo DAP (descongelado adicionado de $10 \%$ de plasma seminal). Após a adição dos tratamentos as amostras permaneceram em banho-Maria a temperatura de $37^{\circ} \mathrm{C}$ até o final das análises (120 minutos). Os quatro grupos experimentais foram avaliados em três períodos distintos, 0 (5 minutos após a diluição dos tratamentos, para a estabilização das amostras), 60 e 120 minutos.

\subsubsection{Análise computadorizada da cinética espermática - CASA}

Com a finalidade de examinar o padrão de motilidade dos espermatozoides (figura $5 \mathrm{~A}$ ), as amostras foram analisadas pelo sistema de análise computadorizada do sêmen (CASA) através do software Sperm Class Analysis (SCA - Microptics Barcelona, Espanha) no Laboratório de Andrologia e Tecnologia de Embriões Suínos (LATES-FMVZ/USP). As 
características analisadas foram: motilidade total (\%), motilidade progressiva (\%), velocidade de trajeto (VAP, $\mu \mathrm{m} / \mathrm{s}$ ), velocidade progressiva (VSL, $\mu \mathrm{m} / \mathrm{s}$ ), velocidade curvilinear (VCL, $\mu \mathrm{m} / \mathrm{s}$ ), amplitude do deslocamento lateral da cabeça (ALH, $\mu \mathrm{m}$ ), frequência de batimento (BCF, Hz), retilinearidade (STR, \%) e linearidade (LIN, \%). Conjuntamente a estas análises foi realizado o ajuste da ferramenta Edit/Sort para os valores de ALH > 3,5 $\mu \mathrm{m}$ e VCL $>97$ $\mu \mathrm{m} / \mathrm{s}$ (SCHIMIDT; KAMP, 2004), que avaliou a porcentagem de células hiperativadas (figura 5B) na amostra.

Figura 5 - Análise computadorizada da motilidade através do software Sperm Class Analyzer

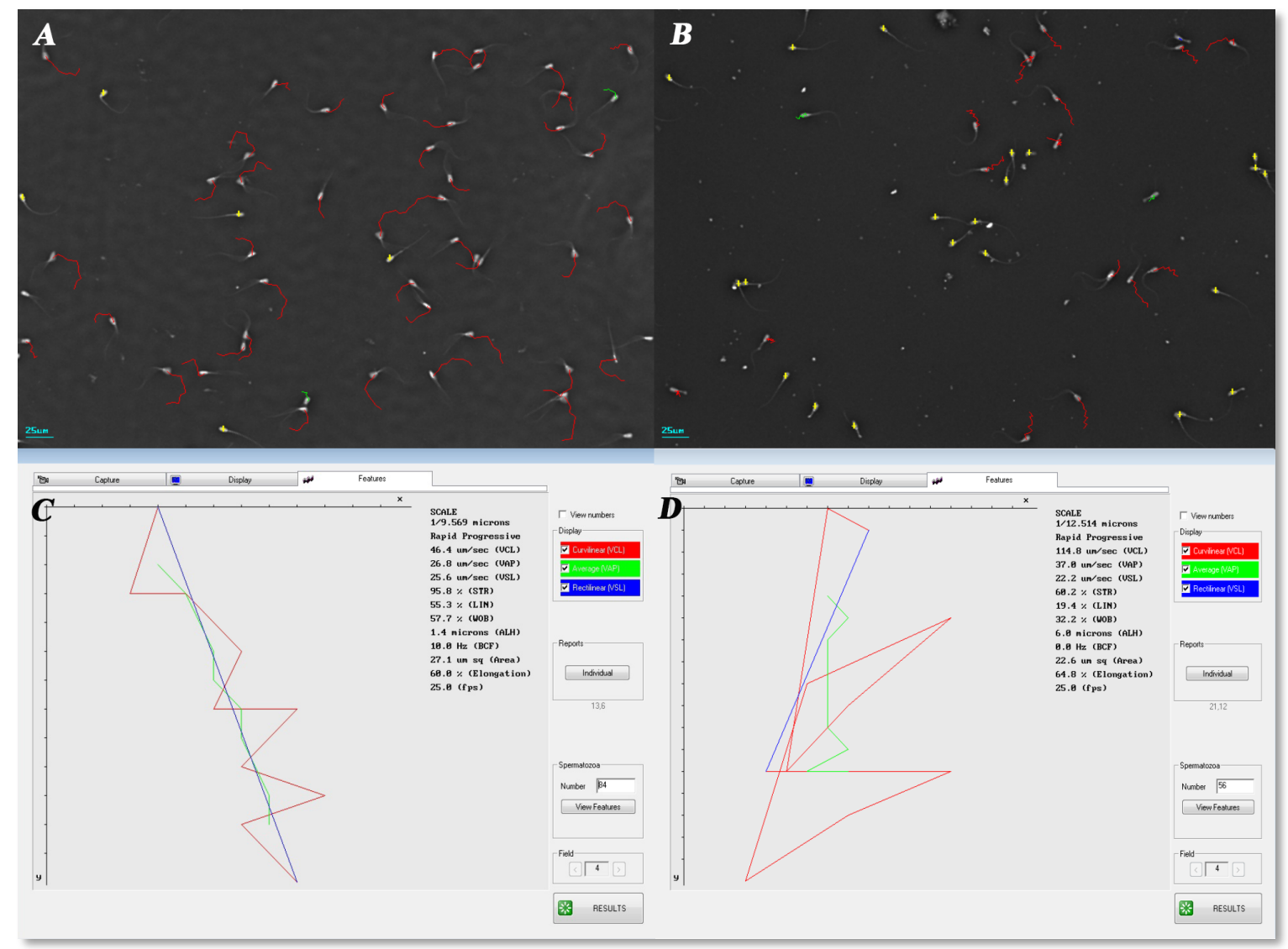

Fonte (TORRES, M. A., 2015)

A) Campo de análise capturado, amostra in-natura, os espermatozoides marcados em vermelho foram classificados como rápidos, os em verde apresentam velocidade média, em azul são os espermatozoides considerados lentos e aqueles marcados em amarelo são os espermatozoides estáticos. B) Campo de análise 
capturado, amostra descongelada, os espermatozoides marcados em vermelho foram classificados como rápidos, os em verde apresentam velocidade média, em azul são os espermatozoides considerados lentos e aqueles marcados em amarelo são os espermatozoides estáticos. C) Visualização do movimento de um espermatozoides individual não hiperativado D) Visualização do movimento de um espermatozoides individual considerado como hiperativado segundo o padrão descrito por Schimidt e Kamp (2004).

\subsubsection{Análises por citometria de fluxo}

As análises por citometria de fluxo foram realizadas no Laboratório de Morfofisiologia Molecular e Desenvolvimento (FZEA-USP). Para tanto, após cada período de incubação em banho-Maria a $37^{\circ} \mathrm{C}$, foi retirada uma alíquota de cada um dos tratamentos experimentais e diluídas para uma concentração de $5 \times 10^{6}$ espermatozoides $/ \mathrm{mL}$ em TALP (BAVISTER et al. 1983) ou em meio modificado de Tyrode's (TALPm) contendo $114 \mathrm{mM}$ de $\mathrm{NaCl}, 3,2 \mathrm{mM}$ de $\mathrm{KCl}, 0,5 \mathrm{mM}$ de $\mathrm{MgCl}_{2} \cdot 6 \mathrm{H} 2 \mathrm{O}, 0,4 \mathrm{mM}$ de $\mathrm{NaH}_{2} \mathrm{PO}_{4} \cdot \mathrm{H}_{2} \mathrm{O}, 5 \mathrm{mM}$ de glicose, $10 \mathrm{mM}$ de lactato de sódio, $0,1 \mathrm{mM}$ de piruvato de sódio, $10000 \mathrm{UI} / 100 \mathrm{~mL}$ de penicilina sódica, sendo o pH do meio foi corrigido até 7,4 com o uso de $\mathrm{NaOH} 5 \mathrm{~N}$, essas amostras foram coradas com $33 \mu \mathrm{g} / \mathrm{mL}$ de $\mathrm{H} 33342$ e incubadas por 10 minutos, com intuito de excluir os debris celulares com as mesmas propriedades de tamanho e complexidade interna que os espermatozoides das análises. Após esse período a adição das sondas fluorescentes indicadas para as análises, as amostras de sêmen incubadas foram analisadas no citômetro de fluxo conforme descrito no item 5.1.5. Entretanto, para essas análises foram utilizados outras combinações de sondas fluorescentes as quais foram detectadas nos seguintes tubo fotomultiplicadores: C11 BODIPY ${ }^{581 / 591}$ long pass 502 e band pass 530/15; Merocianina 540 long pass 595 e band pass 610/20nm; Yo-Prol long pass 502 e band pass $530 / 15$. 
5.2.9.1 Avaliação simultânea da integridade das membranas plasmática e acrossomal e potencial de membrana mitocondrial

Das amostras diluídas em TALP, $150 \mu \mathrm{L}$ foram corados e analisados como descrito no item 5.1.9.

5.2.9.2 Desordem lipídica da membrana plasmática

Para a análise da estabilidade da membrana plasmática pela técnica de citometria de fluxo (FLESCH et al., 1999), após a incubação com H3342 descrita no item 5.2.9 as amostras foram incubadas com $0,5 \mu \mathrm{L}$ a sonda fluorescente Yo-Pro-1 (7,5 $\mu \mathrm{M}$-Molecular Probes Inc., Eugene, Oregon, EUA). A membrana plasmática íntegra impede a permeabilização dessa sonda, que se liga ao DNA das células com a membrana plasmática lesada. Após 20 minutos de incubação foram adicionados $0,5 \mu \mathrm{L}$ sonda fluorescente Merocianina $540(810 \mu \mathrm{M}$ Molecular Probes Inc., Eugene, Oregon, EUA) e incubadas por 70 segundos. Após a diluição em $150 \mu \mathrm{L}$ de TALPm, as amostras foram analisadas por citometria de fluxo, no qual foram avaliadas as porcentagens de espermatozoides viáveis (Yo-Pro-1 negativo) com aumento na desordem da bicamada lipídica (Merocianina 540 positivo) (figura 6). 
Figura 6 - Gráficos gerados a partir do software FACSDiva 6.1 para análise da Merocianina-540
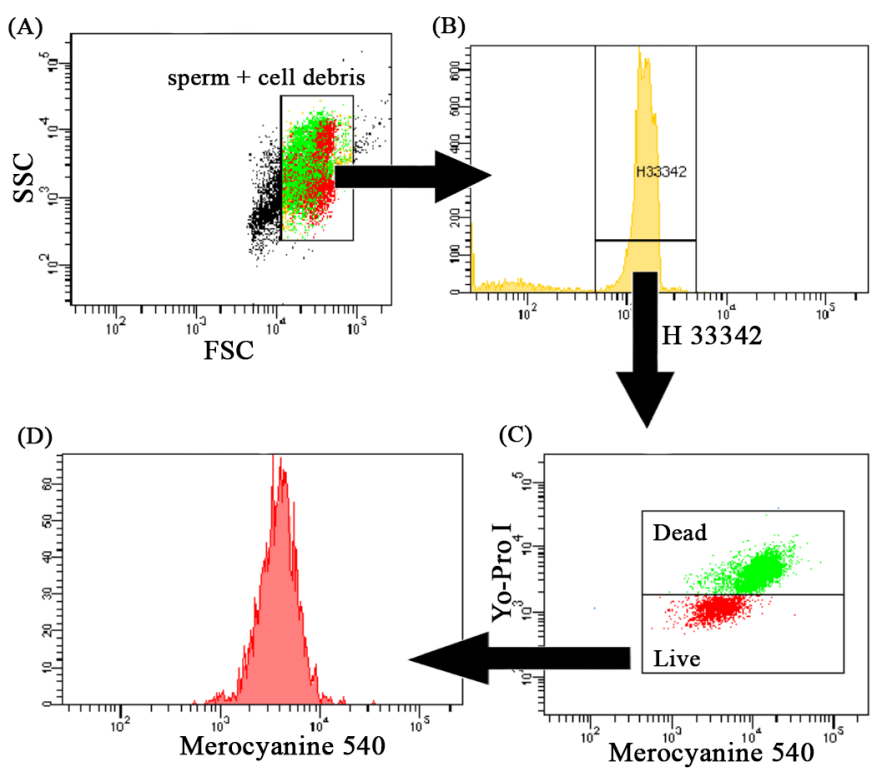

Fonte (TORRES, M. A., 2015)

A) Pré-seleção espermática através do tamanho e complexidade interna das células. B) Seleção da população Hoechst 33342 (H33342) positiva a partir da população pré-selecionada no gráfico A. C) Dot plot com a separação das células positivas (mortas) e negativas (vivas) para Yo-pro1. D) Histograma de PE-A (fotomultiplicador long pass 595 e band pass $610 / 20 \mathrm{~nm}$ ) gerado a partir das células vivas. E) Mediada da intensidade de fluorescência das células positivas para Merocianina-540.

5.2.9.3 Lipoperoxidação dos lipídeos de membrana

Após a incubação com H33342, as amostras foram coradas com $0,5 \mu \mathrm{L}$ da sonda C11BODIPY $^{581 / 591}(1 \mathrm{mg} / \mathrm{mL}$, D-3861, Molecular Probes Inc., Eugene, Oregon, EUA) por 30 minutos a $37^{\circ} \mathrm{C}$ (RAPHAEL et al., 2008). Passado esse período de incubação, foram adicionadas as amostras $3 \mu \mathrm{L}$ de Iodeto de Propídio $(0,5 \mathrm{mg} / \mathrm{mL})$. Após 5 minutos de incubação a $37^{\circ} \mathrm{C}$, os espermatozoides foram diluídos em $150 \mu \mathrm{L}$ de TALPm e transferidos para tubos graduados de $15 \mathrm{~mL}\left(37^{\circ} \mathrm{C}\right)$, para que, no momento de serem analisadas por citometria de fluxo as amostras apresentassem uma concentração de $2,5 \times 10^{6}$ espermatozoides por mL (figura 7). 
Figura 7 - Gráficos gerados a partir do software FACSDiva 6.1 para análise do C11-Bodipy ${ }^{581 / 591}$

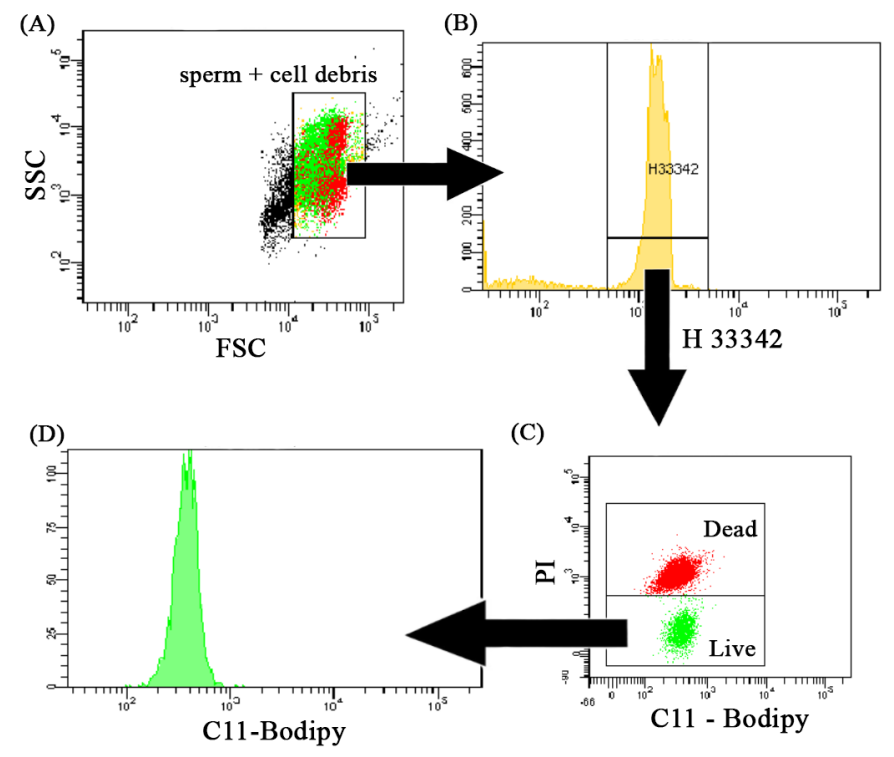

Fonte (TORRES, M. A., 2015)

A) Pré-seleção espermática através do tamanho e complexidade interna das células. B) Seleção da população Hoechst 33342 (H33342) positiva a partir da população pré-selecionada no gráfico A. C) Dot plot com a separação das células positivas (mortas) e negativas (vivas) para Iodeto de Propídio. D) Histograma de FITC-A (fotomultiplicador long pass 502 e band pass 530/15) gerado a partir das células vivas. E) Mediada da intensidade de fluorescência das células positivas para o a sonda fluorescente C11-Bodipy ${ }^{581 / 591}$.

5.2.9.4 Detecção da fosforilação do aminoácido tirosina na superfície da membrana espermática

Diferentemente das outras técnicas, as amostras de sêmen foram diluídas em TALPm a uma concentração final de $1 \times 10^{6}$ espermatozoides $/ \mathrm{mL}$ em um volume final de $150 \mu \mathrm{L}$. Após a coloração com $\mathrm{H} 33342$ (ver item 5.2.9) foram adicionados $0,75 \mu \mathrm{L}$ do anticorpo antifosfotirosina conjugado a uma fluoresceína (100 $\mu \mathrm{g} / \mathrm{mL}$-CLONE PY-20, F0426, SigmaAldrich Co., Saint Louis, Missouri, EUA) e $3 \mu \mathrm{L}$ de Iodeto de Propídio a fim de retirar da análise as células que apresentavam lesão na membrana plasmática. Em seguida a amostra 
foram incubada por 5 minutos a $37^{\circ} \mathrm{C}$ e submetidas à análise por citometria de fluxo (PIEHLER et al., 2006; ANDRADE et al., 2012).

5.3 EXPERIMENTO 3: O plasma seminal e sua influência sobre a fertilidade e a taxa de prenhez das matrizes suínas.

\subsubsection{Local}

O experimento foi realizado no Laboratório de Andrologia e Tecnologia de Embriões Suínos (LATES) e no Laboratório de Pesquisa em Suínos (LPS) ambos pertencentes ao Núcleo de Pesquisa em Suínos da Faculdade de Medicina Veterinária e Zootecnia, localizados no campus administrativo de Pirassununga. O período experimental estendeu-se de maio a junho de 2014.

\subsubsection{Animais}

Foram utilizadas trinta e três marrãs (F2) filhas de fêmeas de linhagem hibrida comercial, as quais foram submetidas a manejo nutricional e sanitário idênticos. No momento da inseminação, as fêmeas apresentavam média de idade de 12,92 meses, peso $156,5 \mathrm{~kg}$, e todos os animais já haviam apresentado no mínimo três ciclos estrais. Os animais ficaram alojados nas dependências do LPS-FMVZ/USP, em gaiolas individuas providas de bebedouro tipo chupeta e comedouro automático. A alimentação foi fornecida duas vezes ao dia (07:00 e as 13:00) a fim de suprir os requerimentos descritos por Rostagno (2005). 


\subsubsection{Coleta e análises iniciais do sêmen}

Idem item 5.1.3 e 5.1.4.

\subsubsection{Criopreservação seminal e tratamentos experimentais}

Para a realização do experimento in -vivo foram utilizados o pool de sêmen dos dois machos com os melhores resultados no experimento in vitro (tabela 2). Para o delineamento desse experimento, optamos por não realizar o tratamento CPP, uma vez que esse tratamento foi adicionado ao experimento in vitro a fim de excluir e averiguar o efeito de centrifugação sob a qualidade espermática, uma vez que, como descrito no item 6 e em seus subsequentes subitens, o processo de centrifugação não foi deletério para a qualidade dos espermatozoides, optamos por focar no objetivo principal desse trabalho no experimento in vivo, com intuito de diminuir o número de fêmeas a serem abatidas. A preparação dos tratamentos CON e CSP, bem como a congelação seminal foi realizada como descrita anteriormente no item 5.2.5.

Tabela 2 - Médias \pm erro padrão das características de cinética espermática e da integridade das membranas plasmática e acrossomal

\begin{tabular}{|c|c|c|c|}
\hline \multicolumn{4}{|c|}{ Motilidade e Integridade de Membranas } \\
\hline & \multicolumn{3}{|c|}{ Tempo de incubação 5 min } \\
\hline & MT & MP & AIMI \\
\hline Hugo & $28,39 \pm 8,62^{\mathrm{a}}$ & $23,83 \pm 8,03^{\mathrm{a}, \mathrm{b}}$ & $17,06 \pm 1,61^{\mathrm{a}}$ \\
\hline Mariano & $27,42 \pm 8,85^{\mathrm{a}, \mathrm{b}}$ & $26,25 \pm 9,97^{\mathrm{a}}$ & $12,9 \pm 1,69^{\mathrm{a}}$ \\
\hline Betão & $24,77 \pm 7,96^{\mathrm{a}, \mathrm{b}}$ & $21,67 \pm 6,69^{\mathrm{a}, \mathrm{c}}$ & $10,57 \pm 1,51^{\mathrm{b}, \mathrm{c}}$ \\
\hline Heitor & $20,06 \pm 5,83^{\mathrm{c}, \mathrm{b}}$ & $17,95 \pm 5,91^{b, c}$ & $6,69 \pm 1,01^{\mathrm{c}, \mathrm{d}}$ \\
\hline Meia Três & $16,94 \pm 6,79^{\mathrm{c}, \mathrm{d}}$ & $14,66 \pm 6,26^{\mathrm{c}, \mathrm{d}}$ & $4,47 \pm 0,36^{\mathrm{d}}$ \\
\hline Homero & $10,94 \pm 3,15^{\mathrm{d}}$ & $9,48 \pm 2,95^{\mathrm{d}}$ & $2,93 \pm 0,86^{\mathrm{d}}$ \\
\hline
\end{tabular}


Fonte (TORRES, M. A., 2015)

Motilidade total (MT), motilidade progressiva (MP) e percentual de células que apresentavam membrana acrossomal e plasmática integras (AIMI). Letras diferentes entre as linhas de uma mesma coluna representam diferença estatística $(\mathrm{p}<0,05)$.

\subsubsection{Obtenção de plasma seminal}

O plasma seminal utilizado nesse experimento foi homologo, diferentemente do experimento in vitro no qual utilizamos plasma seminal autólogo. A escolha pelo plasma seminal homologo se deu em decorrência de viabilizar a execução do experimento, uma vez que as inseminações artificiais foram realizadas com doses inseminantes de $40 \mathrm{~mL}$, o que nos levou a necessidade de $4 \mathrm{~mL}$ de plasma seminal (10\% v:v), o que era impossível ser obtido após a filtração do plasma seminal oriundo da fração rica total. Com isso, foram realizadas coletas prévias de plasma seminal, para as quais o sêmen dos dois cachaços escolhidos para o experimento in vivo foram coletados e mesclados para a formação do pool, o qual foi centrifugado (500 x $g$ por 10 minutos) e o sobrenadante retirado e centrifugado novamente (2400 x $g$ por 30 minutos). O sobrenadante oriundo dessa segunda centrifugação foi separado do pellet de espermatozoides e então depositado sobre o compartimento superior do sistema de filtração a vácuo, o procedimento de filtragem e armazenamento foi realizado como descrito no item 5.2.6.

\subsubsection{Descongelação e rearranjo dos tratamentos experimentais}

As inseminações artificiais foram realizadas, em tempo fixo, com $1,5 \times 10^{9}$ espermatozoides em $40 \mathrm{~mL}$. Para tal, foram descongeladas dez palhetas, de cada tratamento, em banho-Maria a $37^{\circ} \mathrm{C}$ por 30 seg., em seguida, foram diluídas em Beltsville Thawing 
Solution (BTS) para um volume final de $40 \mathrm{~mL}$ e transferidas para bisnagas de inseminações. Outras dez palhetas do tratamento CSP foram descongeladas da mesma maneira e diluídas em BTS com a adição de $10 \%$ de plasma seminal (v: v), para um volume final de $40 \mathrm{~mL}$ e concentração de $1,5 \times 10^{9}$ espermatozoides. As inseminações realizadas imediatamente após a descongelação.

\subsubsection{Preparação das marrãs e inseminações artificiais}

As inseminações foram realizadas pela técnica de inseminação intrauterina (figura 10) (BORTOLOZZO; BERNARDI; WENTZ, 2005), e a mesma foi realizada em tempo fixo. Para isso, utilizou-se um protocolo hormonal (figura 8) baseado no uso de Regumate ${ }^{\circledR}$ (Altrenogest), Novormon ${ }^{\circledR}$ (eCG - gonadotrofina coriônica equina) e Lutropin ${ }^{\circledR}-\mathrm{V}$ (Hormônio luteinizante).

Figura 8 - Linha do tempo esquematizando a hormônio-terapia utilizada para IATF por IAIU

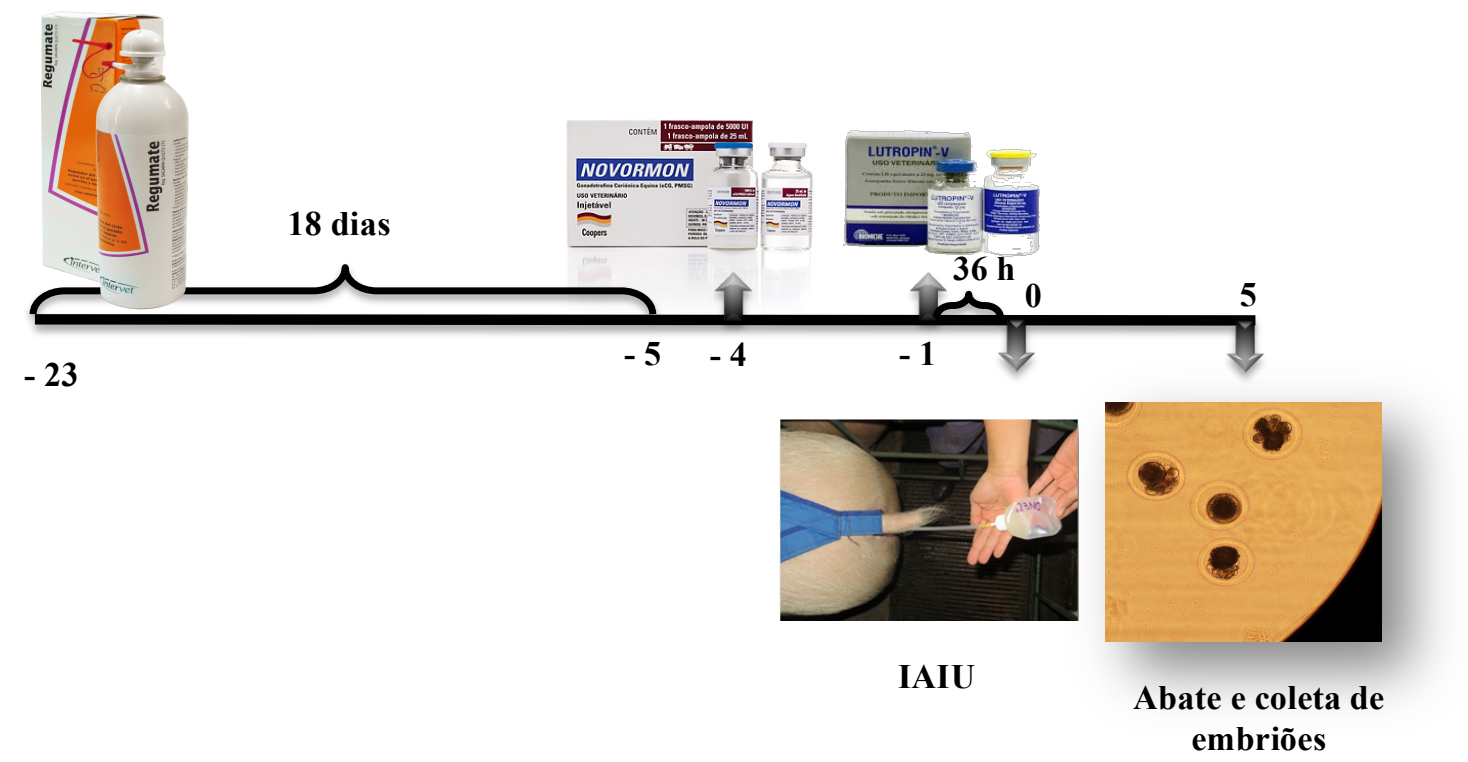

Fonte (TORRES, M. A., 2015) 
O protocolo hormonal utilizado foi baseado no protocolo descrito por Degenstein et al (2008) seguido por algumas alterações. Realizou-se administração oral de $5 \mathrm{~mL}$ de altrenogest $(4 \mathrm{mg} / \mathrm{mL})$ durante 18 dias consecutivos, seguida pela administração intramuscular de 600 UI de eCG 24 horas após a retirada do análogo da progesterona. O intervalo entre a droga folículo estimulante e a indutora da ovulação foi de 72 horas (CANDINI et al 2004), e foram administradas (por via intramuscular) 2,5mg de LH (GAMA et al 2005). As inseminações (figura 9) intrauterinas foram realizadas 36 horas após a indução da ovulação (CANDINI et al 2001).

Figura 9 - Inseminação intrauterina em tempo fixo
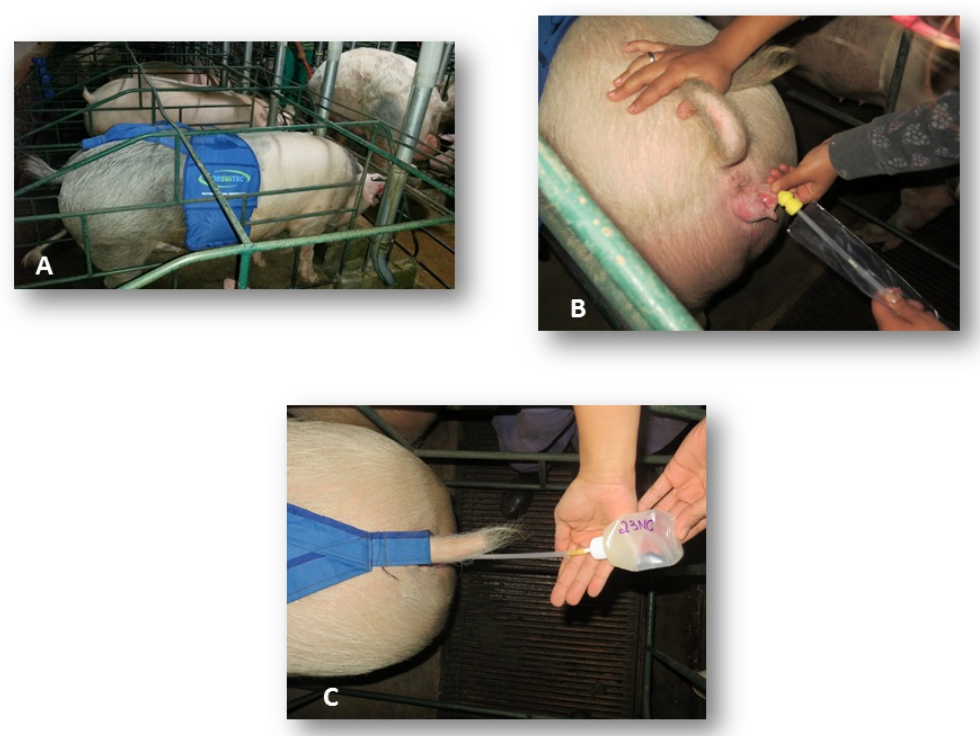

Fonte (TORRES, M. A., 2015)

A) Fêmea preparada para inseminação com bolsa auxiliar. B) Introdução da pipeta de inseminação intrauterina.

C) Pipeta e cateter de inseminação intrauterino introduzidos e inseminação com sêmen suíno descongelado. 


\subsubsection{Abate, coleta e avaliação dos embriões suínos}

O abate das fêmeas suínas, para coleta do trato reprodutivo, atendeu a normas legais e de bioética. Anteriormente a eletro narcose, foi introduzida na cérvix das fêmeas uma pipeta de inseminação artificial, visando evitar o refluxo de urina para o interior do útero. $\mathrm{O}$ processo de retirada do aparelho reprodutivo se deu logo após a sangria, através de uma incisão sobre a linha branca na região inguinal e retirada o trato reprodutivo como um todo, em seguida foi realizada a sutura da musculatura, tecidos adjacentes e pele, permitindo que a carcaça seguisse a linha de abate normal.

O conjunto composto por cérvix, útero, tubas uterinas e ovários foi então acondicionado em sacos plásticos identificados e transportado, em temperatura ambiente, acondicionados em isopor para o LPS. O aparelho reprodutivo foi, primeiramente, posicionado, respeitando sua posição anatômica (figura 10A), permitindo assim, a identificação dos antímeros direito e esquerdo. Os ovários foram então retirados do conjunto e identificados, e a partir desses, foi averiguada a taxa de ovulação (número de corpos lúteos) (figura 10B). Procedeu-se então, a dissecação da tuba uterina, a partir do óstio abdominal da tuba uterina em direção à junção útero-tubária, e cerca de três centímetros após o óstio uterino da tuba uterina foram colocadas duas pinças hemostáticas tipo Kelly e realizada uma secção entre as mesmas, separando-se assim, tuba uterina e corno uterino. Aproximadamente $10 \mathrm{~cm}$ após a segunda pinça colocada no útero, foram colocadas outras duas pinças, e uma nova secção entre elas foi realizada, separou-se assim, a porção do corpo uterino que foi lavada para a coleta de embriões.

Para a lavagem da tuba uterina, foram utilizados cerca de $6 \mathrm{~mL}$ de PBS, os quais foram introduzidos através do óstio abdominal do tuba uterina com auxílio de um tomcat acoplado a uma seringa de $20 \mathrm{~mL}$, foi realizada massagem em toda a extensão do órgão a fim de desprender os embriões que, por ventura, estivessem aderidos à parede (figura 10C). Essa lavagem foi realizada sobre placa de petri, previamente aquecida, e o conteúdo dispensado 
sobre a mesma (figura 10D). Um procedimento semelhante foi realizado com a porção coletada do corno uterino, para tal, introduziu-se o tomcat na porção seccionada após a tuba uterina, mantendo a outra extremidade fechada com auxílio de uma pinça hemostática, e introduziu-se cerca de $14 \mathrm{~mL}$ de PBS e realizou-se movimentos em forma de "s", uma das extremidade foi aberta e o conteúdo drenado para uma placa de petri com auxílio de massagem em toda extensão da porção lavada. O mesmo procedimento foi realizado para ambas porções, direita e esquerda.

Figura 10 - Processo de lavagem uterina e coleta de embriões

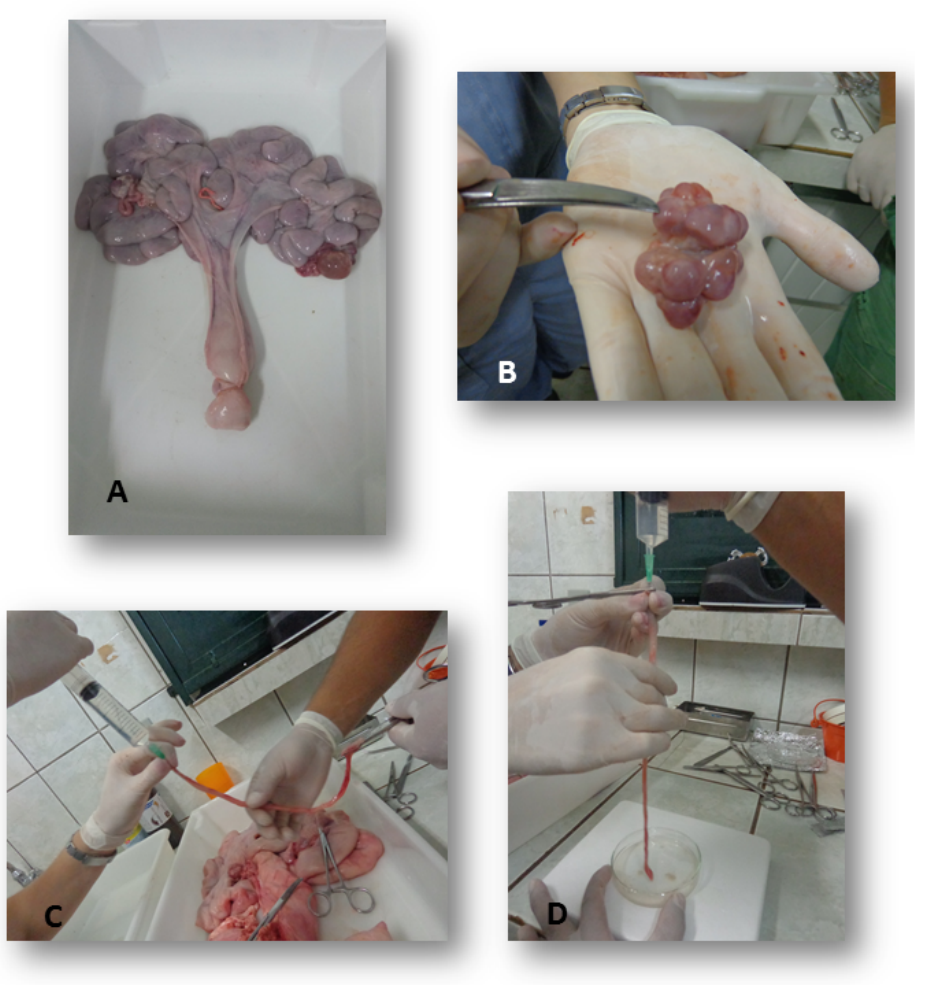

Fonte (TORRES, M. A., 2015)

A) Posicionamento uterino de acordo com a anatomia suína. B) Contagem de corpos lúteos. C) Lavagem da tuba uterina com PBS acrescido de 1\% de soro fetal bovino. D) Acondicionamento do lavado em placas de petri para análise sob esteriomicroscopia. 
O lavado foi avaliado sob esteriomicroscopia em aumento de $20 \mathrm{x}$, e realizada a contagem e classificação embrionária (figura 11). As variáveis analisadas foram: taxa de prenhez precoce (TP), sendo consideradas prenhes as fêmeas que apresentavam alguma estrutura fecundada, e taxa de fertilidade (TF), calculada a partir da porcentagem das estruturas fertilizadas sobre as estruturas recuperadas.

Figura 11 - Avaliação sob esteriomicroscopia e microscopia de epifluorescência do lavado uterino e tubário

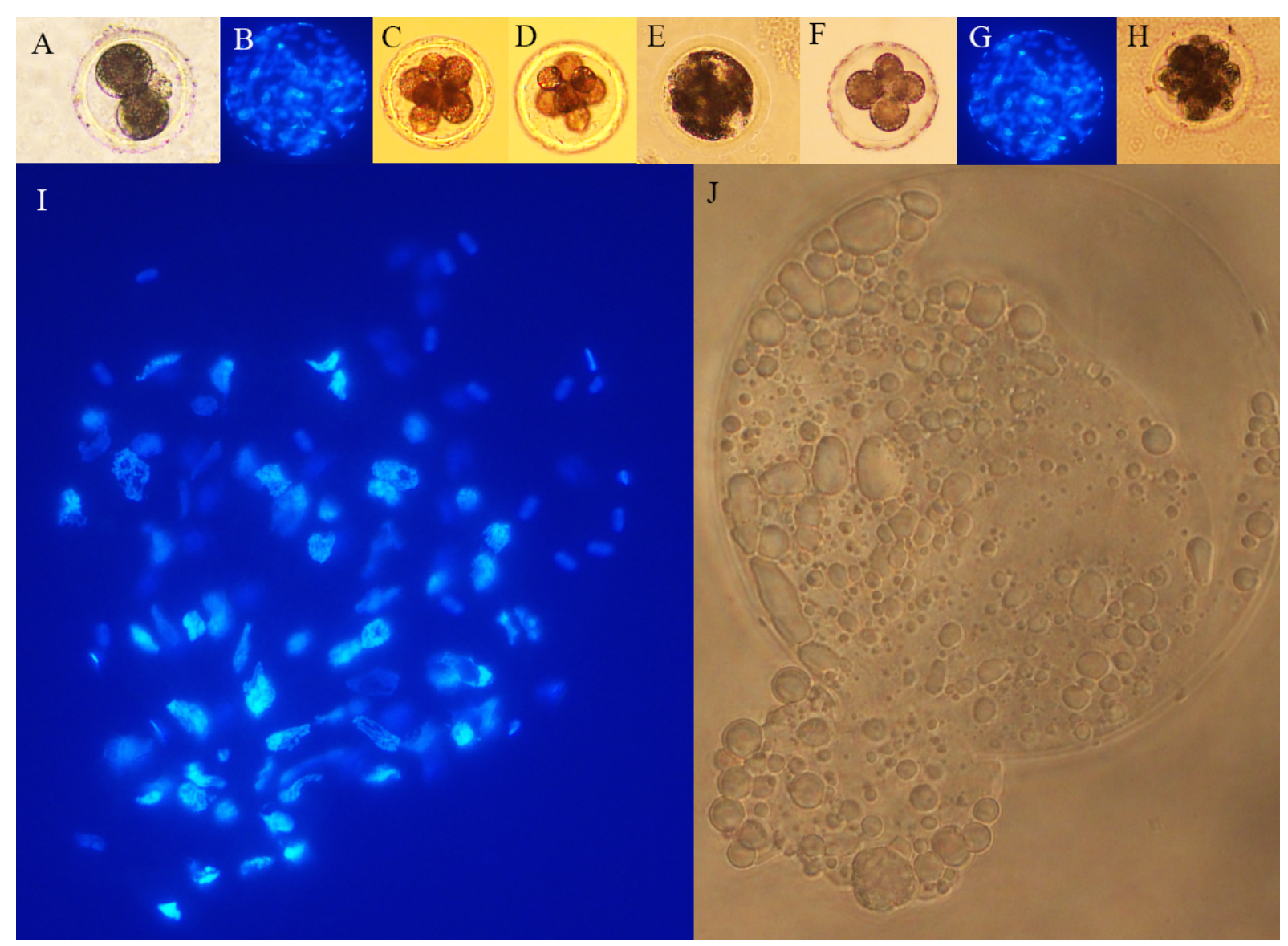

Fonte (TORRES, M. A., 2015)

A) Embrião com duas células; B) Mórula expandida corada com Hoechst 33342; C) Mórula; D) Mórula; E) Oócito degenerado não fecundado; F) Embrião com quatro células; G) Mórula expandida corada com Hoechst 33342; H) Mórula expandida; I) Blastocisto em eclosão corado com Hoechst 33342; J) Blastocisto em eclosão em campo claro. 


\subsection{ANÁLISE ESTATÍSTICA}

Os experimentos descritos nesse trabalho foram delineados em blocos casualizados, nos quais os tratamentos foram considerados o fator principal, para tanto cada animal foi considerado um bloco, e a partição do ejaculado (dependendo do número de tratamentos) uma unidade experimental. Os dados obtidos foram analisados pelo MIXED (SAS, 2002). No experimento 1 o arranjo dos tratamentos foi realizado em níveis (T0, T25, T50, T75 e T100) e avaliados por regressão polinomial. Para verificar a relação entre a motilidade total dos espermatozoides e a população espermática que apresentava integridade das membranas plasmática e acrossomal e alto potencial de membrana mitocondrial (PIAIA), foi realizado uma análise de correção linear de Pearson. Para os experimentos 2 e 3, quando não houve interação entre os tratamentos e os tempo de incubação pós descongelação, para as variáveis obtidas pelas análise das características de motilidade, coloração quádrupla, peroxidação e desordem lipídica da membrana plasmática, fosforilação do aminoácido tirosina e taxa de fertilidade, os efeitos de tempo e tratamento foram estudados independentemente. Os efeitos de tempo foi analisados pelo teste de PDIFF do SAS MIXED, enquanto os efeitos de tratamentos foram avaliados pelo teste de Tukey-Kramer. A taxa de prenhes foi considerada de distribuição binária e analisada com a utilização do GLIMMIX do SAS. Todos os resultados apresentados no item 6. estão apresentados em média \pm erro padrão a média (SEM), foram considerados significativos os resultados com $\mathrm{p}<0,05$. 


\section{RESULTADOS}

"Por vezes sentimos que aquilo que fazemos não é señ̃o uma gota de água no mar. Mas o mar seria menon se the faltasse uma gota". 


\section{RESULTADOS}

Nessa seção serão descritos os resultados obtidos a partir dos experimentos previamente delineados.

6.1 EXPERIMENTO 1: Validação da técnica de análise simultânea da integridade das membranas plasmática e acrossomal e potencial de membrana mitocondrial espermática por citometria de fluxo.

A técnica de citometria de fluxo para análise simultânea da integridade da membrana plasmática e acrossomal o potencial de membrana mitocondrial foi capaz de detectar $\left(\mathrm{R}^{2}=\right.$ 0,9356; $\mathrm{p}<0,0061$ ) os diferentes percentuais dos respectivos tratamentos (figura 12) de células viáveis em cada um dos cinco tratamentos (figura 13A). O total de células PIAIAP (membrana plasmática e acrossomal integras e com alto potencial de membrana mitocondrial) detectado pela técnica de coloração quadrupla por citometria de fluxo foi positivamente correlaciona $(r=0,9402 ; p<, 0001)$ com a motilidade total (figura 13B).

Figura 12 - Hierarquia dos tratamentos T100, T75, T50, T25 e T0, baseados na porcentagem de células viáveis esperadas em cada amostra. Representação gráfica da diminuição, esperada, da viabilidade celular entre os cinco tratamentos

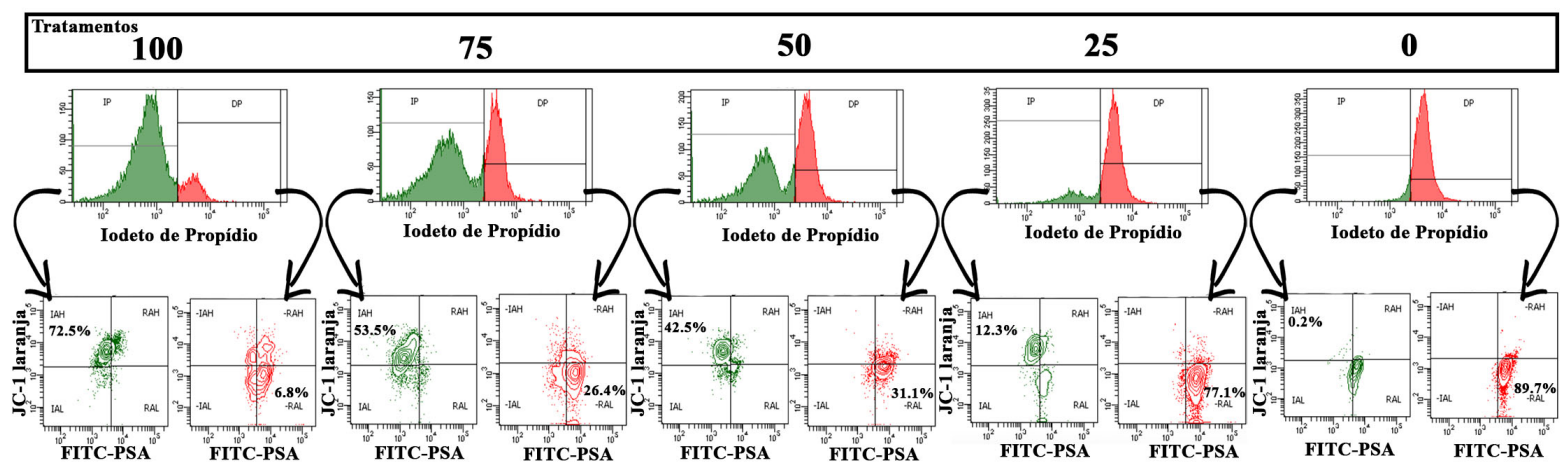

Fonte (TORRES, M. A., 2015)

A) Histograma para identificação e diferenciação das populações espermática com membrana plasmática íntegra (MI; iodeto de propídeo negativo) e lesionada (ML; iodeto de propídeo positivo); B) Gráfico tipo dot plot para 
análise do potencial de membrana mitocondrial (eixo y) e da integridade acrossomal (eixo x) da população espermática oriunda do gate MI, e identificação das quatro populações celulares encontradas; C) Gráfico tipo dot plot para análise do potencial de membrana mitocondrial (eixo y) e da integridade acrossomal (eixo x) da população espermática oriunda do gate ML, e identificação das quatro populações celulares encontradas.

Figura 13 - Coloração quádrupla para análise espermática por citometria de fluxo
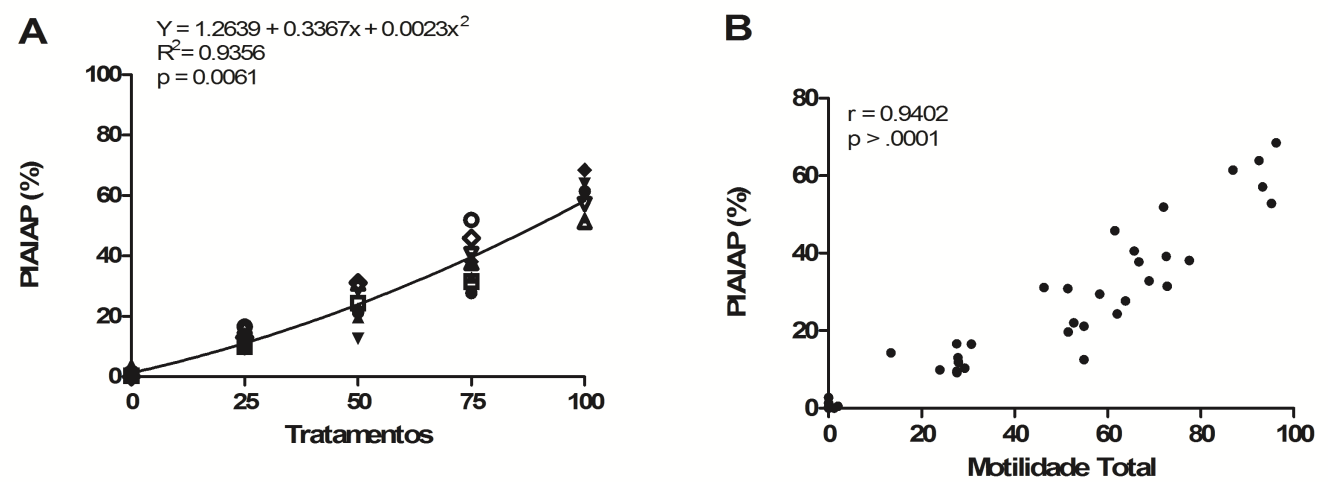

Fonte (TORRES, M. A., 2015)

(A) Regressão polinomial entre os tratamentos $(0,25,50,75$ e 100) e as células PIAIA (membrana plasmática e acrossomal integra e alto potencial de membrana mitocondrial). (B) Correlação entre motilidade total e PIAIA.

\subsection{EXPERIMENTO 2: O plasma seminal e sua influência sob as características espermáticas.}

As variáveis avaliadas no presente experimento foram estudadas quanto a interação tempo $\mathrm{x}$ tratamento, ou quando este não foi significativo $(\mathrm{p}>0,05)$ os efeitos de tempo $\mathrm{e}$ tratamento foram estudados separadamente. 


\subsubsection{Análise computadorizada da cinética espermática - CASA}

A presença de plasma seminal independe do momento da adição, antes ou após a congelação melhora $(\mathrm{p}<0,05)$ a motilidade total e progressiva dos espermatozoides suínos quando comparado a ausência de plasma seminal (figura 14A). Além disso, os tratamentos com plasma seminal foi capaz de melhorar o padrão de cinética espermática, com o aumento $(\mathrm{p}<0,05)$ da velocidade de trajeto (figura 14B) e da linearidade (figura 14C) melhorando a qualidade do movimentos dos espermatozoides suínos pós-descongelação. $\mathrm{O}$ processo de centrifugação prévio a congelação seminal não foi deletério $(\mathrm{p}>0,05)$ a nenhum parâmetro da cinética espermática (figura 14).

As características de motilidade foram influenciadas pelo tempo de incubação, sendo que a LIN e BCF foram menos afetadas, mantendo-se estável por 60 minutos antes de diminuir $(\mathrm{p}<0,05)$ no tempo 120 , enquanto as outras características (MT, MP, VAP, VCL, VSL, ALH e hiperativação) apresentaram a primeira queda $(\mathrm{p}<0,05)$ já com 60 minutos de incubação, e outra queda após 120 minutos $(\mathrm{p}<0,05$; figura 15). Por outro lado, a retilinearidade, apresentou interação entre tempo e tratamento $(\mathrm{p}<0,05)$, sendo que a adição de plasma seminal após a descongelação do sêmen suíno é capaz de sustentar a retilinearidade dos espermatozoides por mais tempo quando comparado com as amostras sem plasma seminal (tabela 3 ). 
Figura 14 - Média \pm erro padrão da média do efeito de tratamento sob as características da cinética espermática
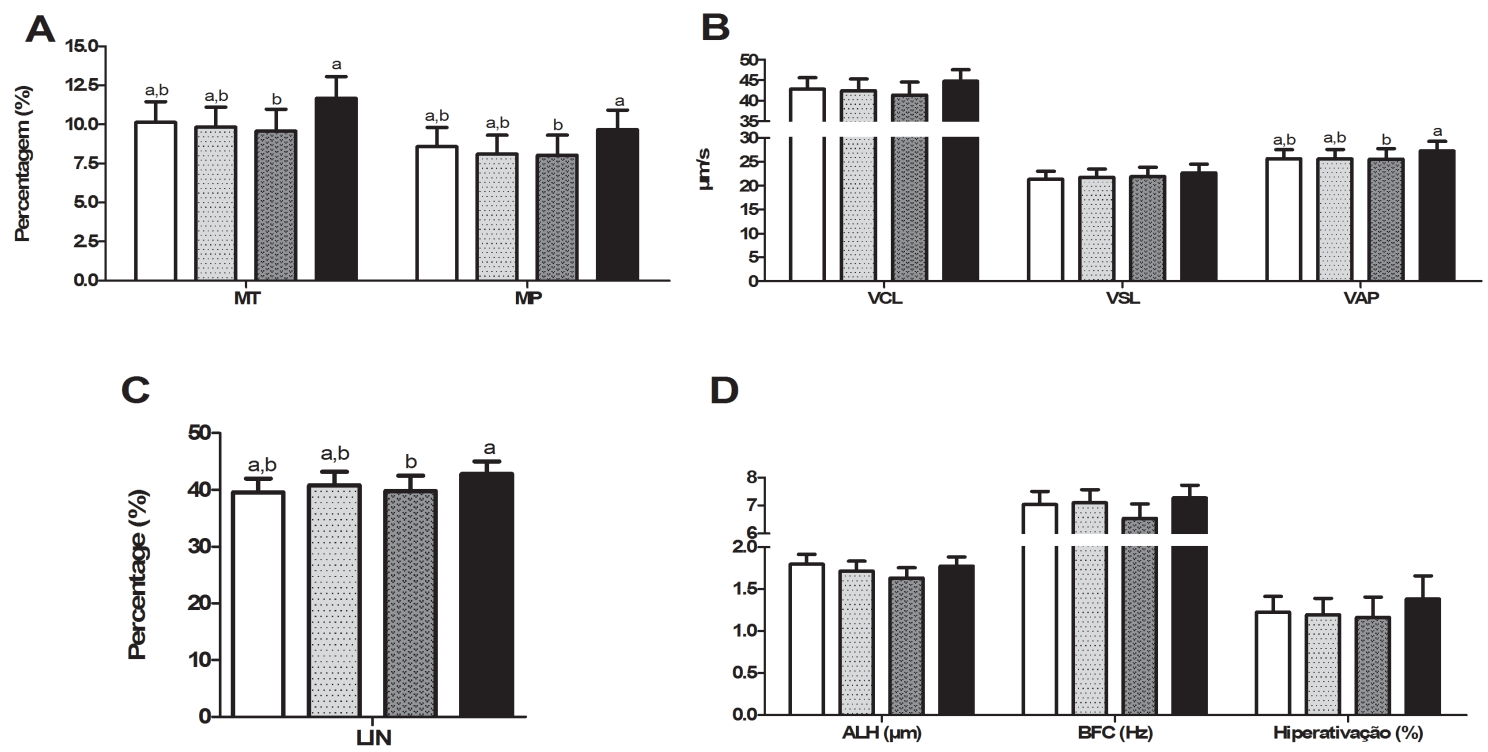

$\square$ CON $\square$ CPP

CSP DAP

Fonte (TORRES, M. A., 2015)

A) MT: motilidade total; MP: motilidade progressiva; B) VCL: velocidade cuvelinear; VSL: velocidade progressiva; VAP: velocidade de trajeto; C) LIN: linearidade; D) ALH: amplitude de deslocamento lateral da cabeça; BCF: frequência de batimento. $\mathrm{CON}$ - controle; $\mathrm{CPP}$ - centrifugado suspendido em próprio plasma seminal (PS); CSP - centrifugado sem PS; DAP - descongelado adicionado de $10 \%$ de PS. Letras diferentes em uma mesma variável representa diferença significativa entre os tratamentos $(\mathrm{p}<0,05)$.

Tabela 3: Média \pm erro padrão da média da interação tempo x tratamento para a variável retilinearidade (STR). CON - controle; CPP - centrifugado suspendido em próprio plasma seminal (PS); CSP - centrifugado sem PS; DAP - descongelado adicionado de $10 \%$ de PS. Letras diferentes na mesma linha representam diferença $(\mathrm{p}<$ $0,05)$ entre os tratamentos dentro de um mesmo tempo de analise.

\begin{tabular}{ccccc}
\hline & CON & CPP & CSP & DAP \\
\hline 5 & $83,02 \pm 0,58^{\mathrm{b}}$ & $86,31 \pm 1,04^{\mathrm{a}}$ & $87,04 \pm 0,7^{\mathrm{a}}$ & $86,87 \pm 0,91^{\mathrm{a}}$ \\
60 & $82,26 \pm 1,11$ & $81,65 \pm 1,05$ & $82,56 \pm 1,18$ & $81,19 \pm 1,08$ \\
120 & $34,73 \pm 7,65^{\mathrm{a}, \mathrm{b}}$ & $36,82 \pm 7,63^{\mathrm{a}, \mathrm{b}}$ & $25,58 \pm 7,5^{\mathrm{b}}$ & $48,87 \pm 6,37^{\mathrm{a}}$ \\
\hline
\end{tabular}

Fonte (TORRES, M. A., 2015) 
Figura 15 - Média \pm erro padrão da média do efeito de tempo sob as características da cinética espermática.

Fonte (TORRES, M. A., 2015)

A) MT: motilidade total; MP: motilidade progressiva; B) VCL: velocidade cuvelinear; VSL: velocidade progressiva; VAP: velocidade de trajeto; C) LIN: linearidade; D) ALH: amplitude de deslocamento lateral da cabeça; BCF: frequência de batimento. Letras diferentes em uma mesma variável representam diferença significativa entre os tempos $(\mathrm{p}<0,05)$.
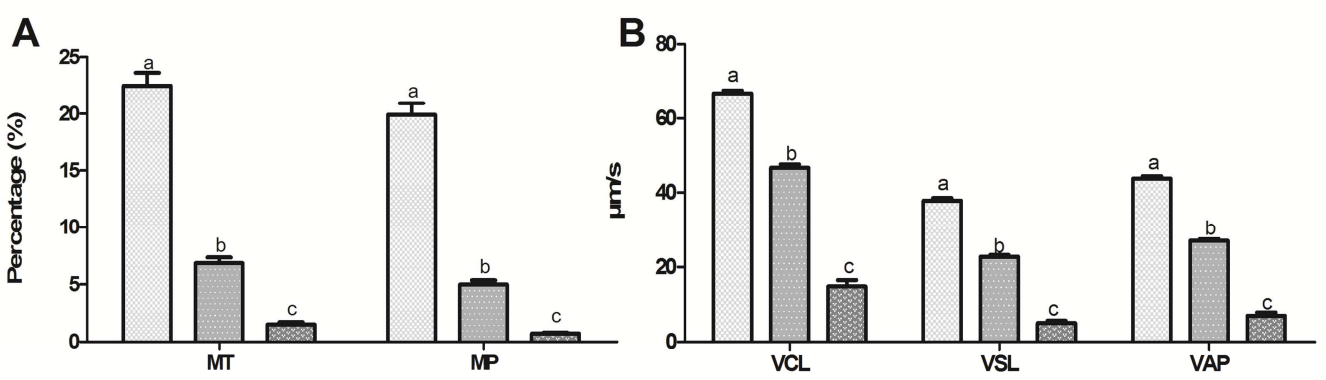

C

D
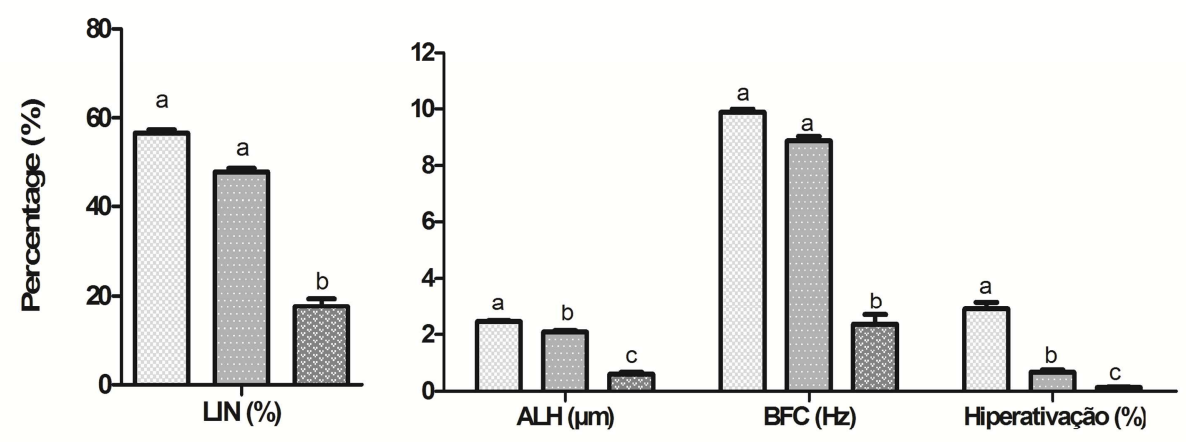

$5 \square 60 \square 120$

\subsubsection{Análises por citometria de fluxo}

6.2.2.1 Avaliação simultânea da integridade das membranas plasmática e acrossomal e potencial de membrana mitocondrial 
A presença de plasma seminal da fração rica do ejaculado suíno, independente do momento da adição (antes da criopreservação, ou após a descongelação) não $(p>0,05)$ foi capaz de melhorar o percentual de células com membrana plasmática e acrossomal integras e alto $\Delta \psi$ m (PIAIAP), bem como não diminuíram $(\mathrm{p}>0,05)$ o percentual de células mortas com acrossoma reacionado e baixo $\Delta \psi \mathrm{m}$ (PLARBP; figura 16A). O plasma seminal da fração rica do ejaculado adicionado ao meio de descongelação do sêmen suíno não foi capaz (p > $0,05)$ de reverter os efeitos deletérios $(\mathrm{p}<0,05)$ da ausência de plasma seminal durante a congelação do sêmen suíno sob a população espermática com membrana plasmática e acrossomal integra e baixo $\Delta \psi \mathrm{m}$ (PIAIBP; figura 16A). O processo de criopreservação do sêmen suíno na ausência de plasma seminal geram danos $(\mathrm{p}<0,05)$ irreversíveis $(\mathrm{p}<0,05)$ com a adição de plasma seminal ao meio de descongelação, sob a população de células com a membrana plasmática lesionada, acrossomal íntegra e baixo $\Delta \psi \mathrm{m}$ (PLAIBP; figura 16A). A centrifugação pré-congelação do sêmen suíno não causa efeitos deletérios $(p>0,05)$ a nenhuma das variáveis de integridade de membranas analisadas (figura 16A).

Figura 16 - Média \pm erro padrão da média do efeito de tratamento (A) e tempo (B) sob as populações espermáticas avaliadas pela técnica de coloração quádrupla.
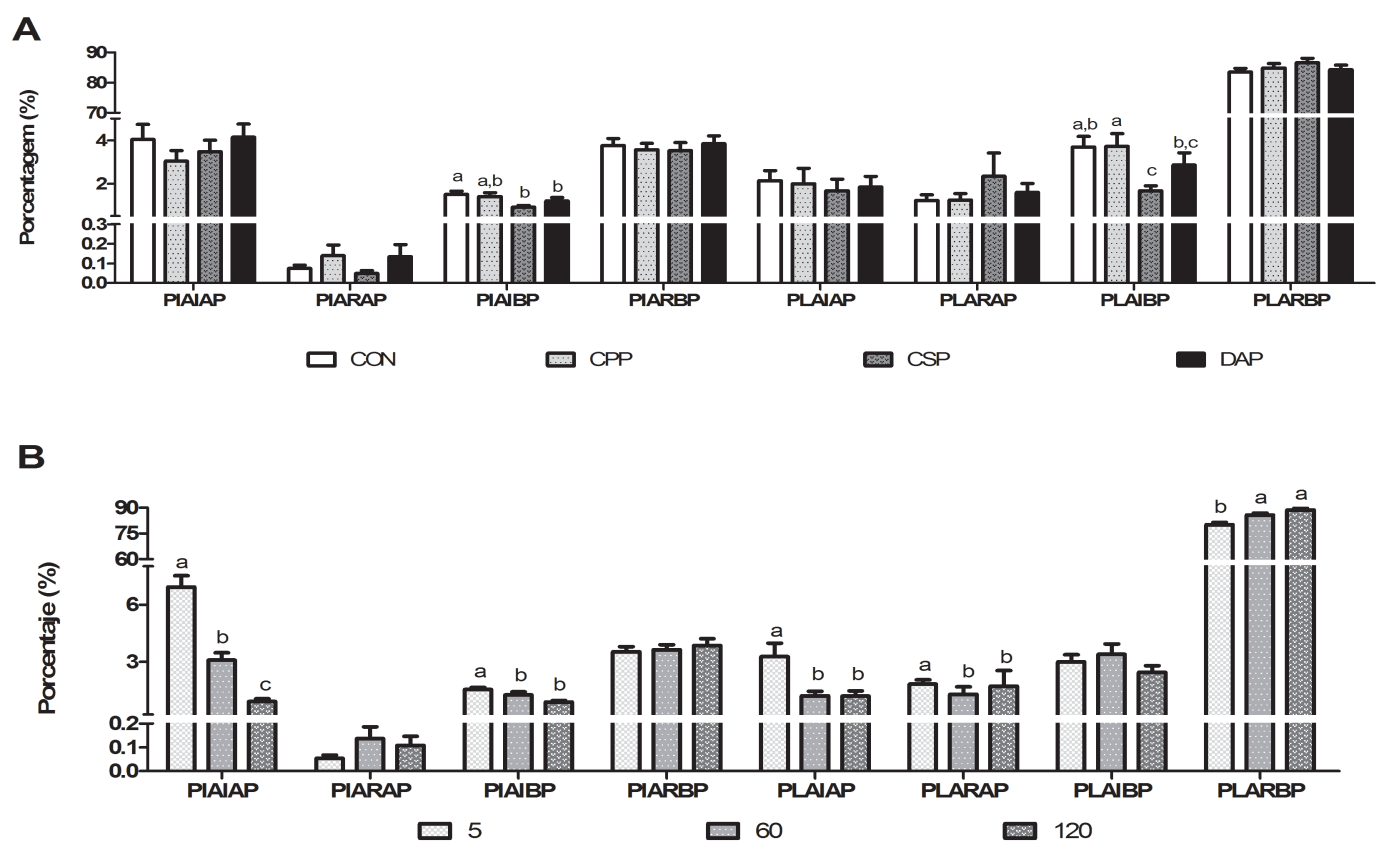
Fonte (TORRES, M. A., 2015)

CON - controle; CPP - centrifugado suspendido em próprio plasma seminal (PS); CSP - centrifugado sem PS; DAP - descongelado adicionado de $10 \%$ de PS. PIAIAP: espermatozoides com membrana plasmática e acrossomal integra e alto $\Delta \psi \mathrm{m}$ (potencial de membrana mitocondrial); PIARAP: espermatozoides com membrana plasmática íntegra, acrossomal reacionada e alto $\Delta \psi \mathrm{m}$; PIAIBP: espermatozoides com membrana plasmática e acrossomal integra e baixo $\Delta \psi \mathrm{m}$; PIARBP: espermatozoides com membrana plasmática íntegra, acrossomal reacionada e baixo $\Delta \psi \mathrm{m}$; PLAIAP: espermatozoides com membrana plasmática lesionada, acrossomal íntegra e alto $\Delta \psi \mathrm{m}$; PLARAP: espermatozoides com membrana plasmática e acrossomal lesionadas e alto $\Delta \psi \mathrm{m}$; PLAIBP: espermatozoides com membrana plasmática lesiona, acrossomal íntegra e baixo $\Delta \psi \mathrm{m}$; PLARBP: espermatozoides com membrana plasmática e acrossomal lesionada e baixo $\Delta \psi \mathrm{m}$. Letras diferentes em uma mesma variável representam diferença significativa $(\mathrm{p}<0,05)$.

O tempo de incubação pós-descongelação do sêmen suíno, diminuiu regressivamente $(\mathrm{p}<0,05)$ o percentual de células IPIAHP, entre todos os tempo de incubação (figura 16B). Por outro lado, as células PIAIBP, PLAIAP (membrana plasmática lesionada, acrossomal íntegra e alto $\Delta \psi \mathrm{m}$ ) e PLARAP (membranas plasmática e acrossomal lesionadas e alto $\Delta \psi \mathrm{m}$ ) apresentaram uma queda $(\mathrm{p}<0,05)$ do percentual entre o tempo 5 e 60 minutos, mantendo-se estável ( $\mathrm{p}>0,05)$ de 60 a 120 minutos (figura 16B). As proporções mais baixas das células consideradas mortas, as PLARBP, foram observadas nos primeiros cinco minutos de incubação a $37^{\circ} \mathrm{C}$ e consecutivamente, aumentaram $(\mathrm{p}<0,05)$ de 60 a 120 minutos de incubação (figura 16B).

\subsubsection{Desordem lipídica da membrana plasmática}

A ausência de plasma seminal da fração rica do ejaculado durante o processo de criopreservação aumentou $(\mathrm{p}<0,05)$ a desordem dos lipídeos de membrana quando comparado com as amostras que passaram pelo mesmo processo de centrifugação mas tiveram a manutenção do plasma seminal durante a criopreservação. A adição pós- 
descongelação não foi capaz de reverter $(p>0,05)$ esse efeito deletério da ausência de plasma seminal da fração rica do ejaculado suíno (figura 17).

Figura 17 - Média \pm erro padrão da média do efeito de tratamento para as características de desordem (a) e peroxidação lipídica (b) da membrana plasmática, e fosforilação do aminoácido tirosina (c).
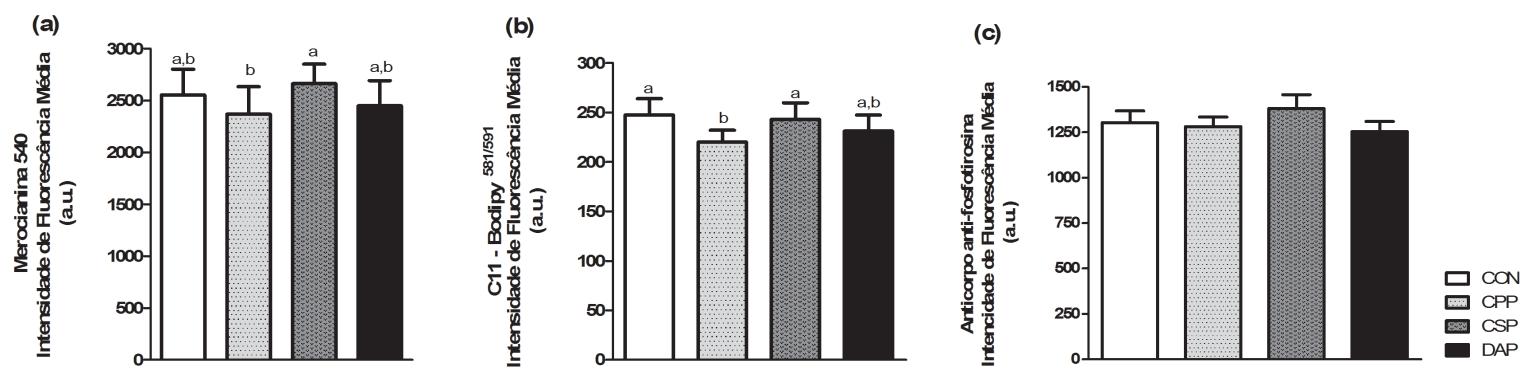

Fonte (TORRES, M. A., 2015)

CON - controle; CPP - centrifugado suspendido em próprio plasma seminal (PS); CSP - centrifugado sem PS; DAP - descongelado adicionado de $10 \%$ de PS. Letras diferentes em uma mesma variável representam diferença significativa entre os tratamentos $(\mathrm{p}<0,05)$.

\subsubsection{Peroxidação dos lipídeos de membrana}

O processo de centrifugação seminal para a concentração dos espermatozoides com intuito de viabilizar a criopreservação em palhetas finas (de 0,5 e/ou 0,25 mL) diminuiu (p < $0,05)$ a peroxidação do lipídeos da membrana plasmática dos espermatozoides considerados vivos (IP negativo) quando comparado com as amostras não centrifugadas (figura 17). A adição de plasma seminal da fração rica do ejaculado suíno ao meio de descongelação do sêmen não diminuiu $(\mathrm{p}>0,05)$ a lipoperoxidação da membrana plasmática, entretanto, sua ausência tão pouco foi deletéria ( $p>0,05$; figura 17). A incubação das amostras seminais a $37^{\circ} \mathrm{C}$ por 60 minutos não alterou $(\mathrm{p}>0,05)$ a peroxidação lipídica da membrana plasmática, 
entretanto após 120 minutos de incubação, a células vivas com maior grau de peroxidação do lipídeos de membrana diminuíram $(\mathrm{p}<0,05)$ quando comparadas com aquelas incubadas por cinco minutos (figura 18).

Figura 18 - Média \pm erro padrão da média do efeito de tempo para as características de peroxidação lipídica da membrana plasmática (a), e fosforilação do aminoácido tirosina (b).

(a)

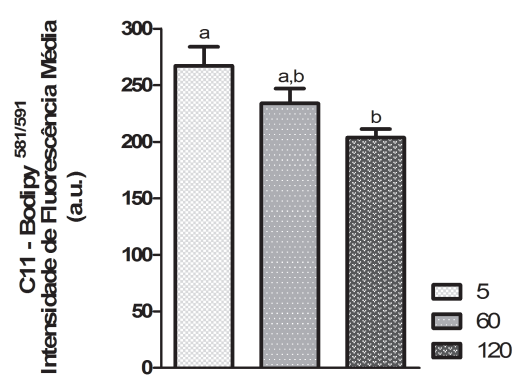

(b)

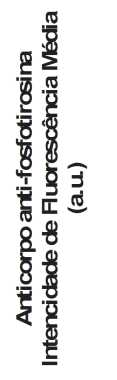

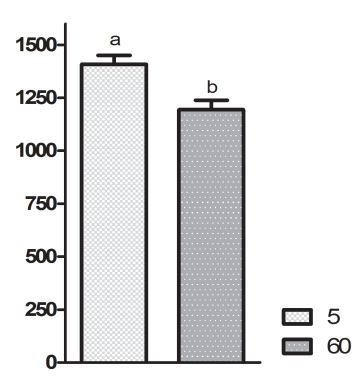

Fonte (TORRES, M. A., 2015)

Letras diferentes em uma mesma variável representam diferença significativa entre os tempo de incubação $(\mathrm{p}<$ $0,05)$.

6.2.2.4 Detecção da fosforilação do aminoácido tirosina na superfície da membrana espermática

A fosforilação do aminoácido tirosina na superfície da membrana plasmática não pode ser revertida $(p>0,05)$ com a adição de plasma seminal da fração rica do ejaculado suíno, tão pouco o processo de centrifugação nem a ausência de plasma seminal aumentaram $(p>0,05)$ a detecção do aminoácido tirosina fosforilado na superfície da membrana plasmática das células vivas (figura 17 ). A incubação a $37^{\circ} \mathrm{C}$ por 60 minutos diminuiu $(p<0,05)$ a detecção do aminoácido tirosina fosforilado, quando comparado aos primeiros cinco minutos de incubação (figura 18). 
6.3 EXPERIMENTO 3: O plasma seminal e sua influência sobre e a fertilidade e prenhes de matrizes suinas.

A fertilidade do sêmen descongelado de suíno, bem como a taxa de prenhes precoce não foram melhoradas pela adição de plasma seminal da fração rica do ejaculado suíno, por outro lado, a ausência da fração acelular do sêmen suíno tão pouco causou prejuízos (p > $0,05)$ as taxas avaliadas (figura 19).

Figura 19 - Média \pm erro padrão da média do efeito de tratamento para a taxa de fertilidade e média da taxa de prenhes precoce.

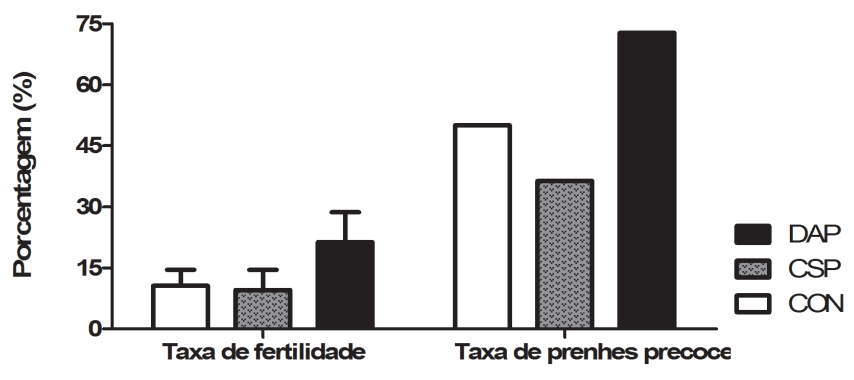

Fonte (TORRES, M. A., 2015)

CON - controle; CSP - centrifugado sem próprio plasma seminal (PS); DAP - descongelado adicionado de $10 \%$ de PS. Letras diferentes em uma mesma variável representam diferença significativa entre os tratamentos $(\mathrm{p}<$ $0,05)$. 


\title{
7 DISCUSSÃO
}

"This is impossible. only if you believe it is"

\author{
O Chapeleiro Maluco em
}

"Alice's adventures in wonderland"

(Lewis Carnoll. 1865) 


\section{DISCUSSÃO}

A criopreservação seminal gera danos aos espermatozoides suínos tanto no que diz respeito a integridade das membranas espermática quanto a sua funcionalidade, acarretando na diminuição do potencial fertilizante dos espermatozoides (RATH et al., 2009). Entretanto, uma técnica que possibilite avaliar todas essas alterações simultaneamente é difícil de se desenvolver (GRAHAM; KUNZE; HAMMERSTEDT, 1990; BRAUNDMEIER; MILLER, 2001). Por outro lado, a avaliação de múltiplos parâmetros espermáticos em uma mesma amostra é capaz de estimar o potencial fertilizante com maiores chances de sucesso do que a análise de parâmetros individualmente (TARTAGLIONE; RITTA, 2004). Nesse contexto, esse trabalho fornece um técnica de análise espermática por citometria de fluxo capaz de avaliar simultaneamente a integridade das membranas plasmática e acrossomal e o potencial das membranas mitocondriais simultaneamente em uma mesma amostra. A técnica de análise espermática com a coloração quádrupla por citometria de fluxo é uma boa alternativa para mesma técnica de coloração espermática anteriormente descrita pode Andrade et al., (2007) e Celeghini et al., (2007) por microscopia de epifluorescência. Ambas as técnicas são precisas e acuradas, entretanto, a técnica de citometria de fluxo possui a vantagem de ser uma técnica objetiva e que é capaz de analisar um grande número de células em um curto espaço de tempo (EISERT, 1981), por outro lado, é uma técnica custosa possuindo essa desvantagem frente a técnica por epifluorescência. Portanto, ambas a técnicas de análise simultânea da integridade das membranas plasmática e acrossomal e do potencial das membranas mitocondriais podem ser realizadas com alta acurácia, mas a escolha da melhor técnica dependa das condições e disponibilidades laboratoriais.

A retirada do plasma seminal para a criopreservação do sêmen suíno gera alterações na cinética espermática (CREMADES et al., 2005), entretanto esse passo é necessário para a concentração dos espermatozoides (GÓMEZ-FERNÁNDEZ et al., 2012) permitindo o envase em palhetas de 0,25 e $0,5 \mathrm{~mL}$. Por outro lado, esse efeito prejudicial resultante da retirada do plasma seminal pode ser revertido pela adição de plasma seminal oriundo da fração rica do ejaculado suíno ao meio de descongelação do sêmen, como observamos nesse trabalho. 
Entretanto, independente do momento em que o plasma seminal entra em contato com os espermatozoides (durante a criopreservação, ou após a descongelação) é possível observar a melhora tanto no percentual de motilidade total e progressiva quanto na qualidade do movimento quando comparado aos espermatozoides criopreservados e descongelados na ausência de plasma seminal. Tal resultado entra em desacordo com o principio de que a manutenção do plasma seminal durante a criopreservação é prejudicial a qualidade espermática (OKAZAKI et al., 2009). Embora nosso trabalho não tenha sido capaz de evidenciar o papel do plasma seminal da fração rica do ejaculado suíno na hiperativação espermática, a qualidade do movimento dos espermatozoides suínos na presença de plasma seminal evidenciaram um movimento mais linear, com o aumento da velocidade de trajeto e da linearidade quando comparado àqueles na ausência de plasma seminal.

A membrana plasmática e a membrana acrossomal externa são as estruturas espermáticas mais criosensíveis (SALAMON; MAXWELL, 1995), sendo esses os principais sítios dos danos causados pela criopreservação, que resultam em estresse osmótico, choque frio, e formação de gelo intra e extracelular (NEILD et al., 2005). Alternativas para melhorar e/ou reverter esse danos oriundos da criopreservação tem sido amplamente estudados, e o plasma seminal surgiu como uma alternativa a muito tempo, e essa fração seminal acelular é capaz de diminuir os efeitos da criopreservação (PIEHLER et al., 2006). Isso provavelmente ocorre devido as vantagens que a Sperm-peak portion e a fração rica do ejaculado suíno possuem frente ao ejaculado como um todo, como a maior resistência ao choque frio, reação acrossomal prematura e estabilidade das membranas (HERNÁNDEZ et al., 2007a). Entretanto, esses benefícios do plasma seminal não foram observados em nosso estudo no que diz respeito a viabilidade espermática, uma vez que, a população espermática com membrana plasmática e acrossomal intactas e alto potencial de membrana mitocondrial não foi alterada pela presença ou pela ausência de plasma seminal, diferentemente de alguns relatos anteriores (BRAUNDMEIER; MILLER, 2001; FLESCH et al., 2001; GARCIA et al., 2010; PETRUNKINA; HARRISON, 2013) e também de relatos em sêmen equino (BAKER et al., 2004). Por outro lado, a partir dos resultados obtidos e da literatura abordada, é possível postular que a ausência na melhora na integridade das membranas plasmática e acrossomal e potencial de membrana mitocondrial na presença do plasma seminal da fração rica em espermatozoides do ejaculado suíno possivelmente não ocorreu pois os espermatozoides 
oriundos dessa fração são por natureza mais resistentes, dificultando assim a ação benéfica do plasma seminal sobre essas características.

O plasma seminal da fração rica do ejaculado suíno é uma mistura complexa da secreção epididimária com pequena proporções de secreções prostáticas e vesiculares (RODRÍGUEZ-MARTÍNEZ et al., 2011). Em cachaços a maioria das proteínas seminais (90\%) pertencem a família das espermadesinas, a qual pode ser subdividida conforme a habilidade de se ligarem a heparina: proteínas ligadoras de heparina - AQN-1, AQN-3, AWN; e proteínas não ligadoras de heparina - HBP, PSP-I e PSP-II (CABALLERO et al., 2008; GONZÁLEZ-CADAVID et al., 2014). Os monômeros de HBP são capazes de se ligar diretamente a membrana plasmática (CABALLERO et al., 2012) prevenindo não somente a capacitação in vitro mas também as mudanças semelhantes a capacitação induzidas pelo choque frio (VADNAIS; ROBERTS, 2010). Além disso os heterodimeros de PSP-I são capazes de prevenir a capacitação prematura (HOSSAIN et al., 2011b). Apesar dessas evidência que o plasma seminal possui componentes benéficos para a estabilidade da membrana, sua adição ao meio de descongelação não alterou a fluidez da membrana plasmáticas. Entretanto, quando o plasma seminal foi retirado por centrifugação, a fluidez da membrana aumentou, o que nos leva a crer que sua presença é essencial para a criopreservação dos espermatozoides suínos.

A remoção do plasma seminal é uma etapa amplamente utilizada nos protocolos tradicionais de criopreservação do sêmen suíno em decorrência do alto volume ejaculado (GÓMEZ-FERNÁNDEZ et al., 2012). Por outro lado, o plasma representa a fração seminal com a maior capacidade antioxidante, com isso, sua remoção torna as células espermáticas vulneráveis a lipoperoxidação (LPO) em decorrência a depleção dos fatores responsáveis pela remoção das espécies reativas de oxigênio (ERO’s) (GÓMEZ-FERNÁNDEZ et al., 2012; MARSHBURN et al., 2014). Entretanto, nossos resultados não foram capazes de demonstrar esse efeito deletério, os espermatozoides na presença ou na ausência de plasma seminal apresentaram os mesmos níveis de peroxidação da membrana plasmática. Como mencionado anteriormente, a ausência de plasma seminal aumento a fluidez da membrana plasmática, essa alteração na membrana plasmática tem como um dos precursores as ERO's (DE LAMIRANDE et al., 1998; OKAZAKI et al., 2009). Esses resultados nos permitem inferir que as concentrações de ERO's requeridas para iniciar uma reação fisiológica são menores que aquelas necessárias para a indução da LPO. Resultados semelhantes foram observados em 
sêmen equino (DE ANDRADE et al., 2012), no qual a adição de plasma seminal diminuiu a desordem da membrana e a fosforilação da tirosina mas não alterou a LPO.

A proteína pB1 do plasma seminal de suínos pertence a família da FN-2 e possui funções semelhantes a outros membros dessa família (LUSIGAN et al., 2007). Com isso, podemos comparar a ação da pB1 com as BSPs (proteína do plasma seminal bovino) que são as principais constituintes da família $\mathrm{FN}-2$, e são responsáveis pela estabilização da membrana plasmática através da ligação coma fosfatidilcolina (VILLEMURE; LAZURE; MANJUNATH, 2003). Assim a remoção do plasma seminal logo após a ejaculação diminui a interação dos espermatozoides com essa proteína gerando uma maior desestabilização da membrana após a descongelação seminal, como foi observado em nossos resultados.

A fosforilação do aminoácido tirosina é um dos fatores associados aos eventos da cascata da capacitação (CABALLERO et al., 2012), possuindo correlação coma presença de cálcio e bicabornato no meio (CABALLERO et al., 2008). Apesar das inúmeras evidencia já demonstradas que o plasma seminal exerce uma função essencial na físiologia dos espermatozoides (GONZÁLEZ-CADAVID et al., 2014), nossos resultados não demonstraram esse feito benéfico do plasma seminal, bem como também não foram observados efeitos deletérios da ausência do plasma seminal no que diz respeito a fosforilação do aminoácido tirosina na superfície dos espermatozoides descongelados de suínos. É possível que os baixos níveis de fosforilação da tirosina observados em nosso estudo estejam relacionados com os baixos níveis de bicabornato presentes na fração rica do ejaculado suíno (DE ANDRADE et al., 2011), o que tornaria os espermatozoides oriundo dessa fração mais resistentes a esse evento da cascata da capacitação.

Alguns aspectos da fisiologia espermática tem sido altamente correlacionados com as proteínas do plasma seminal. A família das espermadesinas é a proteína mais abundante (90\%) no plasma seminal de suínos (EKHLASI-HUNDRIESER et al., 2005; TALEVI; GUALTIERI, 2010). Essas proteínas tem sido associadas com a formação da reserva espermática no oviduto (DOSTÀLOVÀ et al., 1994b) pela ligação da AQN-1 aos resíduos de manose da membrana apical das células do epitélio do oviduto (TÖPFER-PETERSEN; EKHLASI-HUNDRIESER; TSOLOVA, 2008). Durante a capacitação, a AQN e a AWN atuam como fatores decapacitantes (JONÁKOVÁ et al., 2000) atuando como aceptores de colesterol da membrana espermática, aumentando assim a fluidez da membrana plasmática Finalmente, as espermadesinas atuam interação dos gametas (DOSTÀLOVÀ et al., 1994a), 
sendo que, possivelmente a AQN-3 e a AWN auxiliam no reconhecimento e na ligação entre os gametas (DOSTÀLOVÀ et al., 1994a; TÖPFER-PETERSEN; EKHLASI-HUNDRIESER; TSOLOVA, 2008; VADNAIS; ROBERTS, 2010). Tais fatos nos levam a crer que a adição de plasma seminal da fração rica do ejaculado suíno ao sêmen descongelado poderia aumentar a fertilidade dessas células (HERNÁNDEZ et al., 2007a; GARCIA et al., 2010; OKAZAKI et al., 2012). Entretanto, não foi possível observar efeitos da presença ou ausência do plasma seminal sobre as taxas de fertilidade e prenhez. 


\section{CONCLUSÕES}

"Ando devagar pon que já tive pressa e levo esse sonniso pon que já chonei demais.

Hoje me sinto mais forte, mais feliz quem sabe.

Só levo a centeza de que muito pouco eu sei, eu nada sei"

Tocando em frente

(Renato Teixeira. 1991) 


\section{CONCLUSÕES}

1. A avaliação simultânea da integridade da membrana plasmática e acrossomal e potencial de membrana mitocondrial é possível de se realizar por citometria de fluxo com a associação das sondas fluorescente Hoechst 33342, iodeto de propídeo, PSAFITC e JC-1;

2. A adição de plasma seminal oriundo da fração rica total do ejaculado suíno é capaz de reverter os efeitos da criopreservação, no que diz respeito as alterações nos padrões de motilidade;

3. O plasma seminal oriundo da fração rica total do ejaculado suíno adicionado ao sêmen descongelado de suíno não é capaz de aumentar a taxa de prenhez e a fertilidade de fêmeas suínas. 


\section{CONSIDERAÇÕES FINAIS}

"Nós poderiamos ser muito melhores se não quiséssemos ser tão bons"

(Sigmund Freud) 


\section{CONSIDERAÇÕES FINAIS}

Nosso trabalho expande as perspectivas científicas do uso do plasma seminal, sendo que, o uso do plasma seminal oriundo da fração rica total do ejaculado suíno pode ser uma alternativa para aproveitar melhor o uso dos espermatozoides ejaculados. Além do mais, nossos resultados precisam ser cuidadosamente interpretados, uma vez que, os efeitos da centrifugação pré-criopreservação podem ocasionar confusões para a interpretação do real efeito do plasma seminal.

Embora a ausência de plasma seminal não tenha prejudicado as taxas de fertilidade e prenhez das fêmeas suínas, a adição de plasma seminal após a descongelação dobrou o número de fêmeas inseminadas que apresentaram embriões ao abate, e o número de embriões observados também dobrou no grupo inseminado com a adição de plasma seminal ao meio de descongelação dos espermatozoides suínos. Apesar de ser apenas uma diferença numérica, é possível que em estudos futuros com um maior números de repetições (fêmeas) por tratamento o efeito do plasma seminal seja mais facilmente observado. 


\section{REFERENCIAS}




\section{REFERÊNCIAS}

ABAD, M.; SPRECHER, D. J.; ROSS, P.; FRIENDSHIP, R. M.; KIRKWOOD, R. N. Effect of sperm cryopreservation and supplementing semen doses with seminal plasma on the stablishment of a sperm reservoir in gilts. Reproduction in Domestic Animals, v. 42, p. 149$152,2007$.

ALGHAMDI, A. S.; FOSTER, D. N.; TROEDSSON, M. H. T. Equine seminal plasma reduces sperm binding to polymorphonuclear neutrophils (PMNs) and improves the fertility of fresc semen inseminated into inflamed uteri. Reproduction, v. 127, p. 593-600, 2004.

ALVAREZ, J. G.; STOREY, B. T. Role of glutathione peroxidase in protecting mammalian spermatozoa from loss of motility caused by spontaneous lipid peroxidation. Gamete Research, v. 23, p. 77-90, 1989.

ANDRADE, A. F. C.; DE ARRUDA, R. P.; CELEGHINI, E. C. C.; NASCIMENTO, J.; MARTINS, S. M. M. K.; RAPHAEL, C. F.; MORETTI, A. S. Fluorescent stain method for the simultaneous determination of mitochondrial potential and integrity of plasma and acrosomal membranes in boar sperm. Reproduction in Domestic Animals, v. 42, n. 2, p. 190-194, 2007.

ANDRADE, A. F. C.; ZAFFALON, F. G.; CELEGHINI, E. C. C.; NASCIMENTO, J.; TARRAGÓ, O. F. B.; MARTINS, S. M. M. K.; ALONSO, M. A.; ARRUDA, R. P. Addition of seminal plasma to post-thawing equine semen: What is the effect on sperm cell viability?

Reproduction in Domestic Animals, v. 46, n. 4, p. 682-686, 2011.

ANDRADE, A. F. C.; ZAFFALON, F. G.; CELEGHINI, E. C. C.; NASCIMENTO, J.; BRESSAN, F. F.; MARTINS, S. M. M. K.; DE ARRUDA, R. P. Post-thaw addition of seminal plasma reduces tyrosine phosphorylation on the surface of cryopreserved equine sperm, but does not reduce lipid peroxidation. Theriogenology, v. 77, n. 9, p. 1866-1872.e3, 2012.

BAILEY, J. L.; BILODEAU, J. F.; CORMIER, N. Semen cryopreservation in domestic animals: a damaging and capacitating phenomenon. Journal of Andrology, v. 21, p. 1,7, 2000 .

BAILEY, J. L.; LESSARD, C.; JACQUES, J.; BRÈQUE, C.; DOBRINSKI, I.; ZENG, W.; GALANTINO-HOMER, H. L. Cryopreservation of boar semen and its future importance to the industry. Theriogenology, v. 70, n. 8, p. 1251-1259, 2008.

BAKER, M. A; HETHERINGTON, L.; ECROYD, H.; ROMAN, S. D.; AITKEN, R. J. Analysis of the mechanism by which calcium negatively regulates the tyrosine phosphorylation cascade associated with sperm capacitation. Journal of cell science, v. 117, n. Pt 2, p. 211-222, 2004.

BARRIOS, B.; PÉREZ-PÉ, R.; GALLEGO, M.; TATO, A.; OSADA, J.; MUIÑO-BLANCO, 
T.; CEBRIÁN-PÉREZ, J. A. Seminal plasma proteins revert the cold-shock damage on ram sperm membrane. Biology of Reproduction, v. 63, p. 1531-1537, 2000.

BAVISTER, D.; LORRAINE, M. Development of reimplantation in a defined embryos of the golden culture medium. Biological Trace Element Research, v. 28, p. 235-247, 1983.

BAZER, F. W.; GEISERT, R. D.; ZAVY, M. T. Fertilização, clivagem e implantação. In: HAFEZ, E. S. E. Reprodução animal. São Paulo: Manole, 1995. Cap. 7, p. 191-216.

BRAUNDMEIER, A. G.; MILLER, D. J. The search is on: finding accurate molecular markers of male fertility. Journal of dairy science, v. 84, n. 9, p. 1915-1925, 2001.

BRAVO, M. M.; APARICIO, I. M.; GARCIA-HERREROS, M.; GIL, M. C.; PEÑA, F. J.; GARCIA-MARIN, L. J. Changes in tyrosine phosphorylation associated with true capacitation and capacitation-like state in boar spermatozoa. Molecular Reproduction and Development, v. 71, n. 1, p. 88-96, 2005.

BURKMAN, L. J. Discrimination between nonhyperactivated and classical hyperactivated motility patterns in human spermatozoa using computerized analysis. Fertility and Sterility, v. 55, p. 363-371, 1991.

CABALLERO, I.; PARRILLA, I.; ALMIÑANA, C.; DEL OLMO, D.; ROCA, J.;

MARTÍNEZ, E. A.; VÁZQUEZ, J. M. Seminal plasma proteins as modulators of the sperm function and their application in sperm biotechnologies. Reproduction in Domestic Animals, v. 47, n. SUPPL.3, p. 12-21, 2012.

CABALLERO, I.; VAZQUEZ, J. M.; GARCÍA, E. M.; PARRILLA, I.; ROCA, J.;

CALVETE, J. J.; SANZ, L.; MARTÍNEZ, E. A. Major proteins of boar seminal plasma as a tool for biotechnological preservation of spermatozoa. Theriogenology, v. 70, n. 8, p. 13521355, 2008.

CARVAJAL, G.; CUELlO, C.; RUIZ, M.; VÁZQUEZ, J. M.; MARTÍNEZ, E. A.; ROCA, J. Effects of centrifugation before freezing on boar sperm cryosurvival. Journal of andrology, v. 25, n. 3, p. 389-396, 2004.

CELEGHINI, E. C. C.; DE ARRUDA, R. P.; DE ANDRADE, A. F. C.; NASCIMENTO, J.; RAPHAEL, C. F. Practical techniques for bovine sperm simultaneous fluorimetric assessment of plasma, acrosomal and mitochondrial membranes. Reproduction in Domestic Animals, v. 42, n. 5, p. 479-488, 2007.

COLENBRANDER, B.; RATHI, R.; BEVERS, M. M.; GADELLA, B. M. Capacitation related changes in stallion spermatozoa. In: Proceedings of a workshop entitled From Epidiymis to embryo. Havemeyer Foundation Monograph Series, n. 6, p. 24, 2001.

CREMADES, T.; ROCA, J.; RODRIGUEZ-MARTINEZ, H.; ABAIGAR, T.; VAZQUEZ, J. M.; MARTINEZ, E. A. Kinematic changes during the cryopreservation of boar spermatozoa. Journal of Andrology, v. 26, n. 5, p. 610-618, 2005. 
CROSS, N. L. Multiple effects of seminal plasma on the acrossome reaction of human sperm. Molecular Reproduction and Development, v. 35, p. 316-323, 1993.

DE LAMIRANDE, E.; TASI, C.; HARAKAT, A.; GAGNON, C. Involvement of reactive oxygen species in human sperm acrosome reaction induced by A23187, Iysophosphatidylcholine, and biological fluid ultrafiltrates. Journal of andrology, v. 19, p. 585-594, 1998.

DE LEEUW, F. E.; CHEN, H. C.; COLENBRANDER, B.; VERKLEIJ, A. J. Cold-induced ultrastructural changes in bull and boar sperm plasma membranes. Cryobiology, v. 27, n. 2, p. 171-183, 1990.

DEMOTT, R. P.; SUAREZ, S. S. Hyperactivated sperm progression in the mouse oviduct. Biology of Reproduction, v. 46, p. 779-785, 1992.

DOSTÀlOVÀ, Z.; CALVETE, J. J.; SANZ, L.; HETTEL, C.; RIEDEL, D.; SCHÖNECK, C.; EINSPANIER, R.; TÖPFER-PETERSEN, E. Immunolocalization and quantification of acidic seminal fluid protein (aSFP) in ejaculates, swin-up, and capacitated bull spermatozoa. Biol. Chem., v. 375, p. 457-461, 1994a.

DOSTÀlOVÀ, Z.; CALVETE, J. J.; SANZ, L.; TÖPFER-PETERSEN, E. Quantitation of boar spermadhesins in accessory sex gland fluids and on the surface of epididymal, ejaculated and capacitated spermatozoa. Biochimica et biophysica acta, v. 1200, n. 1, p. 48-54, 1994b. EGITO, A.A.; MARIANTE, A.S.; ALBUQUERQUE, M.S.M. Programa brasileiro de conservação de recursos genéticos animais. Archivos de Zootecnia, v. 51, n. 193-194, p. 3952. 2002.

EISERT, W. G. High resolution optics combined with high spatial reproducibility in flow. Cytometry, v. 1, n. 4, p. 254-259, 1981.

EKHLASI-HUNDRIESER, M.; GOHR, K.; WAGNER, A.; TSOLOVA, M.; PETRUNKINA, A.; TÖPFER-PETERSEN, E. Spermadhesin AQN1 is a candidate receptor molecule involved in the formation of the oviductal sperm reservoir in the pig. Biology of reproduction, v. 73, n. 3, p. 536-545, 2005.

EMILIOZZI, C.; FENICHEL, P. Protein tyrosine phosphorilation is associated with capacitation of human sperm in vitro but is not sufficient for its completion. Biology of Reproduction, v. 56, p. 674-679, 1997.

FERNÁNDEZ-GAGO, R.; DOMÍNGUEZ, J. C.; MARTÍNEZ-PASTOR, F. Seminal plasma applied post-thawing affects boar sperm physiology: A flow cytometry study.

Theriogenology, v. 80, n. 4, p. 400-410, 2013.

FLESCH, F. M.; BROUWERS, J. F.; NIEVELSTEIN, P. F.; VERKLEIJ, A. J.; VAN GOLDE, L. M.; COLENBRANDER, B.; GADELLA, B. M. Bicarbonate stimulated phospholipid scrambling induces cholesterol redistribution and enables cholesterol depletion in the sperm plasma membrane. Journal of cell science, v. 114, n. Pt 19, p. 3543-3555, 2001. 
FULLER, S. J.; WHITTINGHAM, D. G. Effect of cooling mouse spermatozoa to $4^{\circ} \mathrm{C}$ on fertilization and embryonic development. Journal Reproduction and Fertility, v. 108, p. 139-145, 1996.

GADELLA, B. M. Sperm membrane physiology and relevance for fertilization. Animal Reproduction Science, v. 107, n. 3-4, p. 229-236, 2008.

GADELLA, B. M.; RATHI, R.; BEVERS, M. M.; BROUWERS, J. F. H. M.; NEILD, D.; COLENBRANDER, $B$. The role of lipid dynamics in equine sperm plasma membrane function. Havemeyer Foundation Monograph Series, n. 5, p. 24, 2001.

GARCÍA, E. M.; CALVETE, J. J.; SANZ, L.; ROCA, J.; MARTÍNEZ, E. A.; VÁZQUEZ, J. M. Distinct effects of boar seminal plasma fractions exhibiting different protein profiles on the functionality of highly diluted boar spermatozoa. Reproduction in Domestic Animals, v. 44, n. 2, p. 200-205, 2009.

GARCIA, J. C.; DOMINGUEZ, J. C.; PENA, F. J.; ALEGRE, B.; GONZALEZ, R.; CASTRO, M. J.; HABING, G. G.; KIRKWOOD, R. N. Thawing boar semen in the presence of seminal plasma: Effects on sperm quality and fertility. Animal Reproduction Science, v. 119, n. 1-2, p. 160-165, maio 2010.

GARNER, D. L.; THOMAS, C. A.; GRAVANCE, C. G.; MARSHALL, C. E.;

DEJARNETTE, J. M.; ALLEN, C. Seminal plasma addition attenuates the dilution effect in bovine sperm. Theriogenology, n. 56, p. 31-40, 2001.

GARNER, D. L.; HAFEZ, E. S. E. Espermatozoide e plasma seminal. In: Hafez, E. S. E. Reprodução Animal. 7. ed. Barueri: Manole Ltda, 2004. Cap.7, p. 97-110.

GILLAN, L.; EVANS, A. G.; MAXWELL, W. M. C. Capacitation status and fertility of fresh and frozen-thawed ram spermatozoa. Reproduction, Fertility and Development, v. 9, n. 5, p. 481-487, 1997.

GÓMEZ-FERNÁNDEZ, J.; GÓMEZ-IZQUIERDO, E.; TOMÁS, C.; GONZÁLEZ-

BULNES, A.; SÁNCHEZ-SÁNCHEZ, R.; DE MERCADO, E. Inclusion of seminal plasma in sperm cryopreservation of Iberian pig. Animal Reproduction Science, v. 130, n. 1-2, p. 82-90, 2012.

GONZÁLEZ-CADAVID, V.; MARTINS, J. A. M.; MORENO, F. B.; ANDRADE, T. S.; SANTOS, A. C. L.; MONTEIRO-MOREIRA, A. C. O.; MOREIRA, R. A.; MOURA, A. A. Seminal plasma proteins of adult boars and correlations with sperm parameters.

Theriogenology, v. 82, n. 5, p. 697-707, 2014.

GRAHAM, J. K.; KUNZE, E.; HAMMERSTEDT, R. H. Analysis of Sperm Acrosomal Flow Mitochondrial Function Using fertility. Biology of reproduction, v. 43, p. 55-64, 1990.

GREEN, C. E.; WATSON, P. F. Comparison of the capacitation-like state of cooled boar spermatozoa with true capacitation. Reproduction, v. 122, n. 6, p. 889-898, 2001.

GUTHRIE, H. D.; MAXWELL, W. M. C.; JOHNSON, L. A. The effect of seminal plasma 
and dilution rate on the motility and viability of frozen-thawed boar sperm. In:

INTERNACIONAL CONGRESS OF ANIMAL REPRODUCTION, 14., 2000, Estocolmo, Suécia. Abstracts... 2000. p. 143

HAN, H. L.; MACK, S. R.; DE JONGE, C.; ZENEVELD, L. J. D. Inhibition of the human sperm acrosome reaction by a high molecular weight factor from human seminal plasma. Fertility and Sterility, v. 54, p. 1177-1179, 1990.

HANSEN, C.; SRIKANDAKUMAR, A.; DOWNEY, B. R. Presence of follicular fluid in the porcine oviduct and its contribution to the acrosome reaction. Molecular Reproduction and Development, v.30, p.148-153, 1991.

HERNÁNDEZ, M.; ROCA, J.; CALVETE, J. J.; SANZ, L.; MUIÑO-BLANCO, T.; CEBRIÁN-PÉREZ, J. A; VÁZQUEZ, J. M.; MARTÍNEZ, E. A. Cryosurvival and in vitro fertilizing capacity postthaw is improved when boar spermatozoa are frozen in the presence of seminal plasma from good freezer boars. Journal of andrology, v. 28, n. 5, p. 689-697, $2007 \mathrm{a}$.

HERNÁNDEZ, M.; ROCA, J.; GIL, M. A.; VÁZQUEZ, J. M.; MARTÍNEZ, E. a.

Adjustments on the cryopreservation conditions reduce the incidence of boar ejaculates with poor sperm freezability. Theriogenology, v. 67, n. 9, p. 1436-1445, $2007 \mathrm{~b}$.

HO, H. C.; SUAREZ, S. S. Hyperactivation of mammalian spermatozoa: Function and regulation. Reproduction, v. 122, n. 4, p. 519-526, 2001.

HOSSAIN, M. S.; JOHANNISSON, A.; SIQUEIRA, A. P.; WALLGREN, M.;

RODRIGUEZ-MARTINEZ, H. Spermatozoa in the sperm-peak-fraction of the boar ejaculate show a lower flow of $\mathrm{Ca} 2+$ under capacitation conditions post-thaw which might account for their higher membrane stability after cryopreservation. Animal Reproduction Science, v. 128, n. 1-4, p. 37-44, 2011 a.

HOSSAIN, S.; JOHANNISSON, A.; WALLGREN, M.; NAGY, S.; SIQUEIRA, A. P.; RODRIGUEZ-MARTINEZ, H. Flow cytometry for the assessment of animal sperm integrity and functionality: state of the art. Asian Journal of Andrology, v. 13, n. 3, p. 406-419, $2011 b$.

JOHNSON, L. A.; WEITZE, K. F.; FISER, P.; MAXWELL, W. M. C. Storage of boar semen. Animal Reproduction Science, v. 62, n. 1-3, p. 143-172, 2000.

JONÁKOVÁ, V.; MANÁSKOVÁ, P.; KRAUS, M.; LIBERDA, J.; TICHÁ, M. Sperm surface proteins in mammalian fertilization. Molecular reproduction and development, $\mathrm{v}$. 56, n. 2 Suppl, p. 275-277, 2000.

KATILA, T. Sperm-uterine interactions: a review. Animal Reproduction Science, v. 68, p. 267-272, 2001.

LUSIGAN, M. F.; BERGERON, A.; CRÊTE, M. H.; LAZURE, C.; MANJUNATH, P. Induction of epididymal boar sperm capacitation by $\mathrm{pB} 1$ and BSP-A1/-A2 proteins, 
members of the BSP protein family. Biology of reproduction, v. 76, p. 424-432, 2007.

MARQUEZ, B.; SUAREZ, S. S. Different signaling pathways in bovine sperm regulate capacitation and hyperactivation. Biology of Reproduction, v. 70, p. 1626-1633, 2004.

MARSHBURN, P. B.; GIDDINGS, A.; CAUSBY, S.; MATTHEWS, M. L.; USADI, R. S.; STEUERWALD, N.; HURST, B. S. Influence of ejaculatory abstinence on seminal total antioxidant capacity and sperm membrane lipid peroxidation. Fertility and Sterility, v. 102, n. 3, p. 705-710, 2014.

MAXWELL, W. M. C.; EVANS, G.; MORTIMER, S. T.; GILLAN, L.; GELLATLY, E. S.; MCPHIE, C. A. Normal fertility in ewes after cervical insemination with frozen thawed spermatozoa supplemented with seminal plasma. Reproduction Fertility and Development, v. 11, p. 123-126, 1999.

MAXWELL, W. M. C.; JOHNSON, L. A. Membrane status of boar spermatozoa after cooling or cryopreservation. Theriogenology, v. 48, n. 2, p. 209-219, 1997.

MAZUR, P. Freezing of living cells: mechanisms and implications. Am. J. Physiol. Cell. Physiol. 1984; 247: 125-142. American Journal Physiology Cell Physiology, v. 247, p. 125-142, 1984.

MEDRANO, A.; WATSON, P. F.; HOLT, W. V. Investigation of pig sperm plasma membrane reorganization using progesterone-albumin-fluorescein probes. Asian Pacific Journal of Reproduction, v. 1, n. 1, p. 27-33, 2012.

MOORE, H. D. M.; HALL, G. A.; HIBBIT, K. G. Seminal Plasma proteins and the reaction of spermatozoa from intact boars and from boars without seminal vesicles to cooling. Journal of Reproduction and Fertility, v. 47, p. 39-45, 1976.

NAZ, R. K.; RAJESH, P. B. Role of tyrosine phosphorylation in sperm capacitation/acrosome reaction. Reproductive Biology and Endocrinology, v. 2, 2004.

NEILD, D. M.; BROUWERS, J. F.; COLENBRANDER, B.; AGÜERO, A.; GADELLA, B. M. Lipid peroxide formation in relation to membrane stability of fresh and frozen thawed stallion spermatozoa. Molecular reproduction and development, v. 72, p. 230-238, 2005.

NEILD, D. M.; GADELLA, B. M.; CHAVES, M. G; MIRAGAYA, M. H.; COLENBRANDER, B.; AGÜERO, A. Membrane changes during different stages of a freeze-thaw protocol for equine semen cryopreservation. Theriogenology, v. 59, p. 16931705, 2003.

OCHSENDORF, F. R.; BUHL, R.; BASTLEIN, A.; BESCHMANN, H. Glutathione in spermatozoa and seminal plasma of infertile men. Human Reproduction, v. 13, p. 353-359, 1998.

OKAZAKI, T.; ABE, S.; YOSHIDA, S.; SHIMADA, M. Seminal plasma damages sperm during cryopreservation, but its presence during thawing improves semen quality and conception rates in boars with poor post-thaw semen quality. Theriogenology, v. 71, n. 3, p. 
491-498, 2009.

OKAZAKI, T.; AKIYOSHI, T.; KAN, M.; MORI, M.; TESHIMA, H.; SHIMADA, M. Artificial insemination with seminal plasma improves the reproductive performance of frozen-thawed boar epididymal spermatozoa. Journal of Andrology, v. 33, n. 5, p. 990-998, 2012.

PEÑA, F. J.; SARAVIA, F.; NÚÑEZ-MARTÍNEZ, I.; JOHANNISSON, a.; WALLGREN, M.; RODRIGUEZ MARTINEZ, H. Do different portions of the boar ejaculate vary in their ability to sustain cryopreservation? Animal Reproduction Science, v. 93, n. 1-2, p. 101-113, 2006.

PÉREZ, L. J.; VALCÁRCEL, A.; DE LAS HERAS, M. A.; MOSES, D.; BALDASSARRE, $\mathrm{H}$. Evidence that frozen/thawed ram spermatozoa show accelerated capacitation in vitro as assessed by chlortetracycline assay. Theriogenology, v. 46, p. 131-140, 1996.

PETRUNKINA, A.; HARRISON, R. Fluorescence technologies for evaluating male gamete (dys)function. Reproduction in Domestic Animals, v. 48, n. SUPPL.1, p. 11-24, 2013.

PIEHLER, E.; PETRUNKINA, A. M.; EKAHLASI-HUNDRIESER, M.; TÖPFER-

PETERSEN, E. Dynamic quantification of the tyrosine phosphorylation of the sperm surface proteins during capacitaion. Cytometry. Part A, v. 69A, p. 1062-1070, 2006.

POLGE, C. Functional survival of fowl spermatozoa after freezing at $-79^{\circ} \mathrm{C}$. Nature, v. 168 , p. 949-950, 1951.

POLGE, C.; SMITH, A. U.; PARKES, A. S. Revival of spermatozoa after vitrification and dehydration at low temperatures. Nature, 1949.

POTTS, R. J.; NOTARIANNI, L. J.; JEFFERIES, T. M. Seminal plasma reduces exogenous oxidative damage to human sperm, determined by the measurement of DNA strand breaks and lipid peroxidation. Mutation Research, v. 447, p. 249-256, 2000.

PURSEL, V. G.; JOHNSON, L. A.; GERRITS, R. J. Distribution of glutamic oxalacetic tranaminase and lactic dehydrogenase activities inboar semen after cold chock and freezing. Cryobiology, v. 7, n. 2, p. 141-144, 1970.

PURSEL, V. G.; SCHULMAN, L.; JOHNSON, L. A. Effect of holding time on storage of boar spermatozoa at $5^{\circ}$ C. Journal of Animal Science, v. 37, p. 785-789, 1973.

RATH, D.; BATHGATE, R.; RODRIGUEZ-MARTINEZ, H.; ROCA, J.; STRZEZEK, J.; WABERSKI, D. Recent advances in boar semen cryopreservation. Society of Reproduction and Fertility supplement, v. 66, p. 51-66, 2009.

RODRÍGUEZ-GIL, J. E.; ESTRADA, E. Artificial insemination in boar reproduction. In: Bonet, S.; Casas, I.; Holt, W. V.; Yeste, M. Boar Reproduction. Springer, 2013. Berlin, p. 589-608.

RODRIGUEZ-MARTINEZ, H. Role of the oviduct in sperm capacitation. Theriogenology, 
v. 68, n. SUPPL. 1, p. 138-146, 2007.

RODRÍGUEZ-MARTÍNEZ, H.; KVIST, U.; ERNERUDH, J.; SANZ, L.; CALVETE, J. J. Seminal plasma proteins: What role do they play? American Journal of Reproductive Immunology, v. 66, n. SUPPL. 1, p. 11-22, 2011.

RODRIGUEZ-MARTINEZ, H.; WALLGREN, M. Advances in boar semen cryopreservation. Veterinary Medicine International, v. 2011, p. 1-5, 2011.

ROVEGNO, M.; FEITOSA, W. B.; ROCHA, A. M.; MENDES, C. M.; VISINTIN, J. A.; D'AVILA ASSUMPÇÃO, M. E. O. Assessment of post-thawed ram sperm viability after incubation with seminal plasma. Cell and Tissue Banking, v. 14, n. 2, p. 333-339, 2013.

SALAMON, S.; MAXWELL, W. M. . Frozen storage of ram semen II. Causes of low fertility after cervical insemination and methods of improvement. Animal Reproduction Science, v. 38, n. 1-2, p. 1-36, mar. 1995.

SANOCKA, D.; MIESEL, R.; JEDRZEJCZAK, P.; KURPISZ, M. K. Oxidative stress and male infertility. Journal of Andrology, v. 17, p. 449-454, 1996.

SARAVIA, F.; HERNÁNDEZ, M.; WALLGREN, M.; JOHANNISSON, A.; RODRÍGUEZMARTÍNEZ, H. Controlled cooling during semen cryopreservation does not induce capacitation of spermatozoa from two portions of the boar ejaculate. International Journal of Andrology, v. 30, n. 6, p. 485-499, 2007.

SARAVIA, F.; WALLGREN, M.; JOHANNISSON, a.; CALVETE, J. J.; SANZ, L.; PEÑA, F. J.; ROCA, J.; RODRÍGUEZ-MARTÍNEZ, H. Exposure to the seminal plasma of different portions of the boar ejaculate modulates the survival of spermatozoa cryopreserved in MiniFlatPacks. Theriogenology, v. 71, n. 4, p. 662-675, 2009.

SARAVIA, F.; WALLGREN, M.; RODRÍGUEZ-MARTÍNEZ, H. Freezing of boar semen can be simplified by handling a specific portion of the ejaculate with a shorter procedure and MiniFlatPack packaging. Animal Reproduction Science, v. 117, n. 3-4, p. 279-287, 2010.

SCHMIDT, H.; KAMP, G. Induced hyperactivity in boar spermatozoa and its evaluation by computer-assisted sperm analysis. Reproduction, v. 128, n. 2, p. 171-179, 2004.

SHADAN, S.; JAMES, P. S.; HOWES, E. A; JONES, R. Cholesterol efflux alters lipid raft stability and distribution during capacitation of boar spermatozoa. Biology of reproduction, v. 71, n. 1, p. 253-265, 2004.

SIMPSON, A. M.; SWAN, M. A.; WHITE, I. G. Susceptibility of epididymal boar sperm to cold shock and protective action of phosphatidylcholine. Gamete Research. v. 17, p. 355$373,1987$.

SINGER, S. J.; NICOLSON, G. L. The fluid mosaic model of the structure of cell membranes, Science, v. 175, p. 720-731, 1972.

SOSTARIC, E.; AALBERTS, M.; GADELLA, B. M.; STOUT, T. A. E. The roles of the 
epididymis and prostasomes in the attainment of fertilizing capacity by stallion sperm.

Animal Reproduction Science, v. 107, p. 237-248, 2008.

SUAREZ, S. S.; KATZ, D. F.; OVERSTREET, J. W. Movement characteristics and acrosomal status of rabbit spermatozoa recovered at the site and time of fertilization. Biology of Reproduction, v. 29, p. 1277-1287, 1983.

SUAREZ, S. S.; PACEY, A. A. Sperm transport in the female reproductive tract. Human Reproduction Update, v. 12, n. 1, p. 23-37, 2006.

TALEVI, R.; GUALTIERI, R. Molecules involved in sperm-oviduct adhesion and release. Theriogenology, v. 73, n. 6, p. 796-801, 2010.

TARDIF, S.; DUBÉ, C.; CHEVALIER, S.; BAILEY, J. L. Capacitation is associated with tyrosine phosphorylation and tyrosine kinase-like activity of pig sperm proteins. Biology of Reproduction, v. 65, p. 784-792, 2001.

TARTAGLIONE, C. M.; RITTA, M. N. Prognostic value of spermatological parameters as predictors of in vitro fertility of frozen-thawed bull semen. Theriogenology, v. 62, n. 7, p. 1245-1252, 2004.

TIENTHAI, P.; JOHANNISSON, A; RODRIGUEZ-MARTINEZ, H. Sperm capacitation in the porcine oviduct. Animal reproduction science, v. 80, n. 1-2, p. 131-146, 2004.

TÖPFER-PETERSEN, E.; EKHLASI-HUNDRIESER, M.; TSOLOVA, M. Glycobiology of fertilization in the pig. International Journal of Developmental Biology, v. 52, n. 5-6, p. 717-736, 2008.

URNER, F.; SAKKAS, D. Protein phosphorylation in mammalian spermatozoa. Reproduction, v. 125, p. 17-26, 2003.

VADNAIS, M. L.; ALTHOUSE, G. C. Characterization of capacitation, cryoinjury, and the role of seminal plasma in porcine sperm. Theriogenology, v. 76, n. 8, p. 1508-1516, 2011. VADNAIS, M. L.; KIRKWOOD, R. N.; SPECHER, D. J.; CHOU, K. Effects of extender, incubation temperature, and added seminal plasma on capacitation of cryopreserved, thawed boar sperm as determined by chlortetracycline staining. Animal Reproduction Science, v. 90, n. 3-4, p. 347-354, 2005.

VADNAIS, M. L.; ROBERTS, K. P. Effects of seminal plasma on cooling-induced capacitative changes in boar sperm. Journal of andrology, v. 28, n. 3, p. 416-422, 2007.

VADNAIS, M. L.; ROBERTS, K. P. Seminal plasma proteins inhibit in vitro- and coolinginduced capacitation in boar spermatozoa. Reproduction, fertility, and development, v. 22, n. 6, p. 893-900, 2010.

VILLEMURE, M.; LAZURE, C.; MANJUNATH, P. Isolation and characterization of gelatin-binding proteins from goat seminal plasma. Reproductive Biology and

Endocrinology, v. 1, p. 39-48, 2003. 
VISCONTI, P. E.; WESTBROOK, V. A.; CHERTIHIN, O.; DEMARCO, I.; SLEIGHT, S.; DIEKMAN, A. B. Novel signaling pathways involved in sperm acquisition of fertilizing capacity. Journal of Reproductive Immunology, v. 53, p. 133-150, 2002.

VISCONTI, P. E.; KOPF, G. S. Regulation of protein phosphorylation during sperm capacitation. Biology of Reproduction, v. 59, p. 1-6, 1998.

VISCONTI, P.E.; BAILEY, J.; MOORE, G.; PAN, D.; OLDS-CLARKE, P.; KOPF, G. Capacitation of mouse spermatozoa. Part1. Correlation between the capacitation state and protein tyrosine phosphorylation. Development, v. 121, p. 1129-1137, 1995.

WATSON, P. F. Recent developments and concepts in the cryopreservation of spermatozoa and the assessment of their post-thawing function. Reproduction, fertility, and development, v. 7, n. 4, p. 871-891, 1995.

WATSON, P. F. The causes of reduced fertility with cryopreserved semen. Animal Reproduction Science, v. 60-61, p. 481-492, 2000.

WHITE, I. G. Lipids and calcium uptake of sperm in relation to cold shock and preservation: a review. Reproduction, fertility, and development, v. 5, n. 6, p. 639-658, 1993.

WHITE, D. R.; AITKEN, R. J. Relationship between calcium cyclic AMP, ATP and intracellular $\mathrm{pH}$ and the capacity of hamster spermatozoa to express hyperactivated motility. Gamete Research, v. 22, p. 163-177, 1989.

YANAGIMACHI, R. Mammalian fertilization. In: KNOBIL, E.; NEILL, J. D. The Physiology of reproduction. New York: Raven Press, 1994, p. 189-317

YESTE, M. Recent advances in boar sperm cryopreservation: state of the art and current perspectives. Reproduction in Domestic Animals, v. 50, p. 71-79, 2015.

ZASIADCZYK, L.; FRASER, L.; KORDAN, W.; WASILEWSKA, K. Individual and seasonal variations in the quality of fractionated boar ejaculates. Theriogenology, v. 83, n. 8, p. 1287-1303, 2015. 